Cochrane Database of Systematic Reviews

\title{
Effects of peri-operative nonsteroidal anti-inflammatory drugs on post-operative kidney function for adults with normal kidney function (Review)
}

Bell S, Rennie T, Marwick CA, Davey P

Bell S, Rennie T, Marwick CA, Davey P.

Effects of peri-operative nonsteroidal anti-inflammatory drugs on post-operative kidney function for adults with normal kidney function.

Cochrane Database of Systematic Reviews 2018, Issue 11. Art. No.: CD011274.

DOI: 10.1002/14651858.CD011274.pub2.

www.cochranelibrary.com

Effects of peri-operative nonsteroidal anti-inflammatory drugs on post-operative kidney function for adults with normal kidney function (Review) 
TABLE OF CONTENTS

HEADER 1

ABSTRACT

PLAIN LANGUAGE SUMMARY

SUMMARY OF FINDINGS

Figure 1.

BACKGROUND

OBJECTIVES

METHODS

RESULTS

Figure 2.

Figure 3.

DISCUSSION

Figure 4.

AUTHORS' CONCLUSIONS

ACKNOWLEDGEMENTS

REFERENCES

CHARACTERISTICS OF STUDIES

DATA AND ANALYSES

Analysis 1.1. Comparison 1 Acute kidney injury, Outcome $1 \mathrm{AKI}$.

Analysis 2.1. Comparison 2 Serum creatinine, Outcome 1 Serum creatinine (all studies).

Analysis 2.2. Comparison 2 Serum creatinine, Outcome 2 Serum creatinine (excluding high risk of bias).

Analysis 2.3. Comparison 2 Serum creatinine, Outcome 3 Serum creatinine (excluding high attrition bias).

Analysis 2.4. Comparison 2 Serum creatinine, Outcome 4 Serum creatinine (excluding high risk of bias or high attrition bias). ..

Analysis 3.1. Comparison 3 Urine output, Outcome 1 Urine output.

Analysis 4.1. Comparison 4 Need for renal replacement therapy, Outcome 1 RRT.

Analysis 5.1. Comparison 5 Death due to any cause, Outcome 1 Death due to any cause.

Analysis 6.1. Comparison 6 Length of hospital stay, Outcome 1 Length of hospital stay.

ADDITIONAL TABLES

APPENDICES

CONTRIBUTIONS OF AUTHORS

DECLARATIONS OF INTEREST

SOURCES OF SUPPORT

DIFFERENCES BETWEEN PROTOCOL AND REVIEW

INDEX TERMS 
[Intervention Review]

\section{Effects of peri-operative nonsteroidal anti-inflammatory drugs on post- operative kidney function for adults with normal kidney function}

Samira Bell1,2, Trijntje Rennie' ${ }^{1}$, Charis A Marwick², Peter Davey²

1Renal Unit, NHS Tayside, Ninewells Hospital, Dundee, UK. 2Division of Population Health and Genomics, University of Dundee, Dundee, UK

Contact address: Samira Bell, Renal Unit, NHS Tayside, Ninewells Hospital, Dundee, DD1 9SY, UK. samira.bell@nhs.net.

Editorial group: Cochrane Kidney and Transplant Group.

Publication status and date: New, published in Issue 11, 2018.

Citation: Bell S, Rennie T, Marwick CA, Davey P. Effects of peri-operative nonsteroidal anti-inflammatory drugs on post-operative kidney function for adults with normal kidney function. Cochrane Database of Systematic Reviews 2018, Issue 11. Art. No.: CD011274. DOI: 10.1002/14651858.CD011274.pub2.

Copyright (c) 2018 The Cochrane Collaboration. Published by John Wiley \& Sons, Ltd.

\section{A B S T R A C T}

\section{Background}

Nonsteroidal anti-inflammatory drugs (NSAIDs) provide effective analgesia during the post-operative period but can cause acute kidney injury (AKI) when used peri-operatively (at or around the time of surgery). This is an update of a Cochrane review published in 2007.

\section{Objectives}

This review looked at the effect of NSAIDs used in the peri-operative period on post-operative kidney function in patients with normal kidney function.

\section{Search methods}

We searched Cochrane Kidney and Transplant's Specialised Register to 4 January 2018 through contact with the Information Specialist using search terms relevant to this review. Studies in the Specialised Register are identified through searches of CENTRAL, MEDLINE, and EMBASE, conference proceedings, the International Clinical Trials Register (ICTRP) Search Portal and ClinicalTrials.gov.

\section{Selection criteria}

All randomised controlled trials (RCTs) and quasi-RCTs (RCTs in which allocation to treatment was obtained by alternation, use of alternate medical records, date of birth or other predictable methods) looking at the use of NSAIDs versus placebo for the treatment of post-operative pain in patients with normal kidney function were included.

\section{Data collection and analysis}

Data extraction was carried out independently by two authors as was assessment of risk of bias. Disagreements were resolved by a third author. Dichotomous outcomes are reported as relative risk (RR) and continuous outcomes as mean difference (MD) together with their $95 \%$ confidence intervals ( $\mathrm{Cl}$ ). Meta-analyses were used to assess the outcomes of AKI, change in serum creatinine (SCr), urine output, renal replacement therapy (RRT), death (all causes) and length of hospital stay.

\section{Main results}

We identified 26 studies (8835 participants). Risk of bias was high in 17, unclear in 6and low in three studies. There was high risk of attrition bias in six studies.

Only two studies measured AKI. The use of NSAIDs had uncertain effects on the incidence of AKI compared to placebo (7066 participants: RR $1.79,95 \% \mathrm{Cl} 0.40$ to $7.96 ; \mathrm{I}^{2}=59 \%$; very low certainty evidence). One study was stopped early by the data monitoring committee due

Effects of peri-operative nonsteroidal anti-inflammatory drugs on post-operative kidney function for adults with normal kidney function 
to increased rates of AKI in the NSAID group. Moreover, both of these studies were examining NSAIDs for indications other than analgesia and therefore utilised relatively low doses.

Compared to placebo, NSAIDs may slightly increase serum SCr (15 studies, 794 participants: MD $3.23 \mu \mathrm{mol} / \mathrm{L}, 95 \% \mathrm{Cl}-0.80$ to $7.26 ;\left.\right|^{2}=63 \%$; low certainty evidence). Studies displayed moderate to high heterogeneity and had multiple exclusion criteria including age and so were not representative of patients undergoing surgery. Three of these studies excluded patients if their creatinine rose post-operatively.

NSAIDs may make little or no difference to post-operative urine output compared to placebo (6 studies, 149 participants: SMD -0.02, 95\% $\mathrm{Cl}-0.31$ to 0.27$)$. No reliable conclusions could be drawn from these studies due to the differing units of measurements and measurement time points.

It is uncertain whether NSAIDs leads to the need for RRT because the certainty of this evidence is very low ( 2 studies, 7056 participants: RR $1.57,95 \% \mathrm{Cl} 0.49$ to $5.07 ; \mathrm{I}^{2}=26 \%$ ); there were few events and the results were inconsistent.

It is uncertain whether NSAIDs lead to more deaths ( 2 studies, 312 participants: RR $1.44,95 \% \mathrm{Cl} 0.19$ to $11.12 ; \mathrm{I}^{2}=38 \%$ ) or increased the length of hospital stay ( 3 studies, 410 participants: MD 0.12 days, $95 \% \mathrm{Cl}-0.48$ to $0.72 ; \mathrm{I}^{2}=24 \%$ ).

\section{Authors' conclusions}

Overall NSAIDs had uncertain effects on the risk of post-operative AKI, may slightly increase post-operative $\mathrm{SCr}$, and it is uncertain whether NSAIDs lead to the need for RRT, death or increases the length of hospital stay. The available data therefore does not confirm the safety of NSAIDs in patients undergoing surgery. Further larger studies using the Kidney Disease Improving Global Outcomes definition for AKI including patients with co-morbidities are required to confirm these findings. .

\section{PLAIN LANGUAGE SUMMARY}

Effect of nonsteroidal anti-inflammatory medicines on kidney function in patients with normal kidney function undergoing surgery

\section{What is the issue?}

Nonsteroidal anti-inflammatory drugs (NSAIDs) offer effective pain relief following surgery. Acute kidney injury (AKI) is the rapid loss of kidney function. It is associated with high death rate. NSAIDs can lead to AKI in up to $5 \%$ of patients using them. This is increased when there are other stresses placed on the kidney such as surgery. It is therefore important to establish whether these drugs are safe to use as pain relief in patients undergoing surgery. The aim of the review was to examine whether NSAIDs lead to increased rates of AKI in patients with normal kidney function undergoing surgery. We also aimed to examine whether NSAIDs were associated with higher death rates, increased length of hospital stay and need for dialysis.

\section{What did we do?}

We updated a previous review searching the Cochrane Kidney and Transplant Specialised Register until 4 January 2018 for randomised controlled trials (RCTs) comparing NSAIDs with placebo in patients with normal kidney function undergoing surgery.

\section{What did we find?}

We identified 26 studies studying 8835 participants. Risk of bias was high in 17, unclear in six studies and low in three studies. The use NSAIDs had uncertain effects on the incidence of AKI compared to placebo. Quality of evidence was very low due to inconsistencies between the two studies. One study was stopped early by the data monitoring committee due to increased rates of AKI in the NSAID group and both of these studies examined much lower doses of NSAIDs than would usually be used for pain relief. NSAIDs may slightly increase serum creatinine (a marker of kidney function which rises in kidney failure) compared with placebo. Quality of evidence was low. These studies only included fit, healthy patients. No reliable conclusions could be drawn from the studies examining urine output due to the different methods of measuring this. It is uncertain whether the use of NSAIDs leads to an increased need for renal replacement therapy (dialysis), more deaths, or increased length of hospital stay.

\section{Conclusions}

NSAIDs have uncertain effects on the rates of AKI when used in patients with normal kidney function following surgery. It is uncertain whether NSAIDs increase the need for dialysis. The available data therefore does not confirm the safety of NSAIDs in patients undergoing surgery. Further studies including patients with other health problems are required. 


\section{SUMMARY OF FINDINGS}

Summary of findings for the main comparison. Nonsteroidal anti-inflammatory drugs (NSAIDs) versus placebo or no treatment in the peri-operative period

NSAIDs versus placebo or no treatment in the peri-operative period

Patient or population: adults with normal kidney function undergoing surgery

Settings: hospitals, mainly high-income countries (North America or Western Europe)

Intervention: administration of NSAIDs in the peri-operative period

Comparison: placebo or no treatment

\begin{tabular}{|c|c|c|c|c|c|c|}
\hline \multirow[t]{3}{*}{ Outcomes } & \multicolumn{2}{|c|}{ Illustrative comparative risks* $(95 \% \mathrm{CI})$} & \multirow{3}{*}{$\begin{array}{l}\text { Relative effect } \\
(95 \% \mathrm{CI})\end{array}$} & \multirow{3}{*}{$\begin{array}{l}\text { No. of partic- } \\
\text { ipants } \\
\text { (studies) }\end{array}$} & \multirow{3}{*}{$\begin{array}{l}\text { Quality of the } \\
\text { evidence } \\
\text { (GRADE) }\end{array}$} & \multirow[t]{3}{*}{ Comments } \\
\hline & Assumed risk & Corresponding risk & & & & \\
\hline & Placebo & Intervention (NSAID) & & & & \\
\hline $\begin{array}{l}\text { AKI within } \\
30 \text { days of } \\
\text { surgery }\end{array}$ & 12 per 100 & $\begin{array}{l}\mathbf{1 3} \text { per } 100 \\
(12 \text { to } 14)\end{array}$ & $\begin{array}{l}\text { RR } 1.79 \text { (0.40 to } \\
7.96)\end{array}$ & $7066(2)$ & $\begin{array}{l}\oplus \ominus \ominus \ominus \\
\text { very low } \mathbf{1}\end{array}$ & $\begin{array}{l}\text { NAFARM } 2011 \text { was stopped by } \\
\text { study monitoring committee } \\
\text { because of increased risk of } \\
\text { AKI. Both studies used NSAID } \\
\text { doses that were much lower } \\
\text { than would be used for anal- } \\
\text { gesia in usual care. The results } \\
\text { raise serious concerns about } \\
\text { the safety of post-operative } \\
\text { analgesia with NSAIDs in unse- } \\
\text { lected patients }\end{array}$ \\
\hline $\begin{array}{l}\text { SCr increase } \\
\text { within } 30 \\
\text { days of } \\
\text { surgery }\end{array}$ & $\begin{array}{l}\text { The mean difference } \\
\text { in } \mathrm{SCr} \text { in control group } \\
\text { was decreased by }-2.60 \\
\mu \mathrm{mol} / \mathrm{L}\end{array}$ & $\begin{array}{l}\text { The mean difference in } \mathrm{SCr} \text { in the } \\
\text { intervention group was increased } \\
\text { by } 1.52 \mu \mathrm{mol} / \mathrm{L}(-7.4 \text { to } 10.2)\end{array}$ & $\begin{array}{l}\text { Difference in post- } \\
\text { operative SCr in- } \\
\text { creased by } 3.23 \\
\mu \mathrm{mol} / \mathrm{L}(-0.8 \text { to } \\
7.26)\end{array}$ & $794(15)$ & $\begin{array}{l}\oplus \oplus \ominus \odot \\
\text { low }^{2}\end{array}$ & $\begin{array}{l}\text { Heterogeneity was not ex- } \\
\text { plained by pre-specified effect } \\
\text { modifiers (Table 1, Figure } 1 \text { ) }\end{array}$ \\
\hline $\begin{array}{l}\text { RRT within } \\
30 \text { days of } \\
\text { surgery }\end{array}$ & 2 per 1000 & $\begin{array}{l}\mathbf{5} \text { per } \mathbf{1 0 0 0} \\
\text { (2 to } 11)\end{array}$ & $\begin{array}{l}\text { RR } 1.57 \text { (0.49 to } \\
5.07)\end{array}$ & $7056(2)$ & $\begin{array}{l}\oplus \ominus \ominus \ominus \\
\text { very low } 3\end{array}$ & -- \\
\hline $\begin{array}{l}\text { Death (all } \\
\text { causes) }\end{array}$ & 2 per 100 & 3 per 100 & $\begin{array}{l}\text { RR 1.44 (0.19 to } \\
11.12)\end{array}$ & $312(2)$ & $\begin{array}{l}\oplus \ominus \ominus \ominus \\
\text { very low3 }\end{array}$ & -- \\
\hline
\end{tabular}




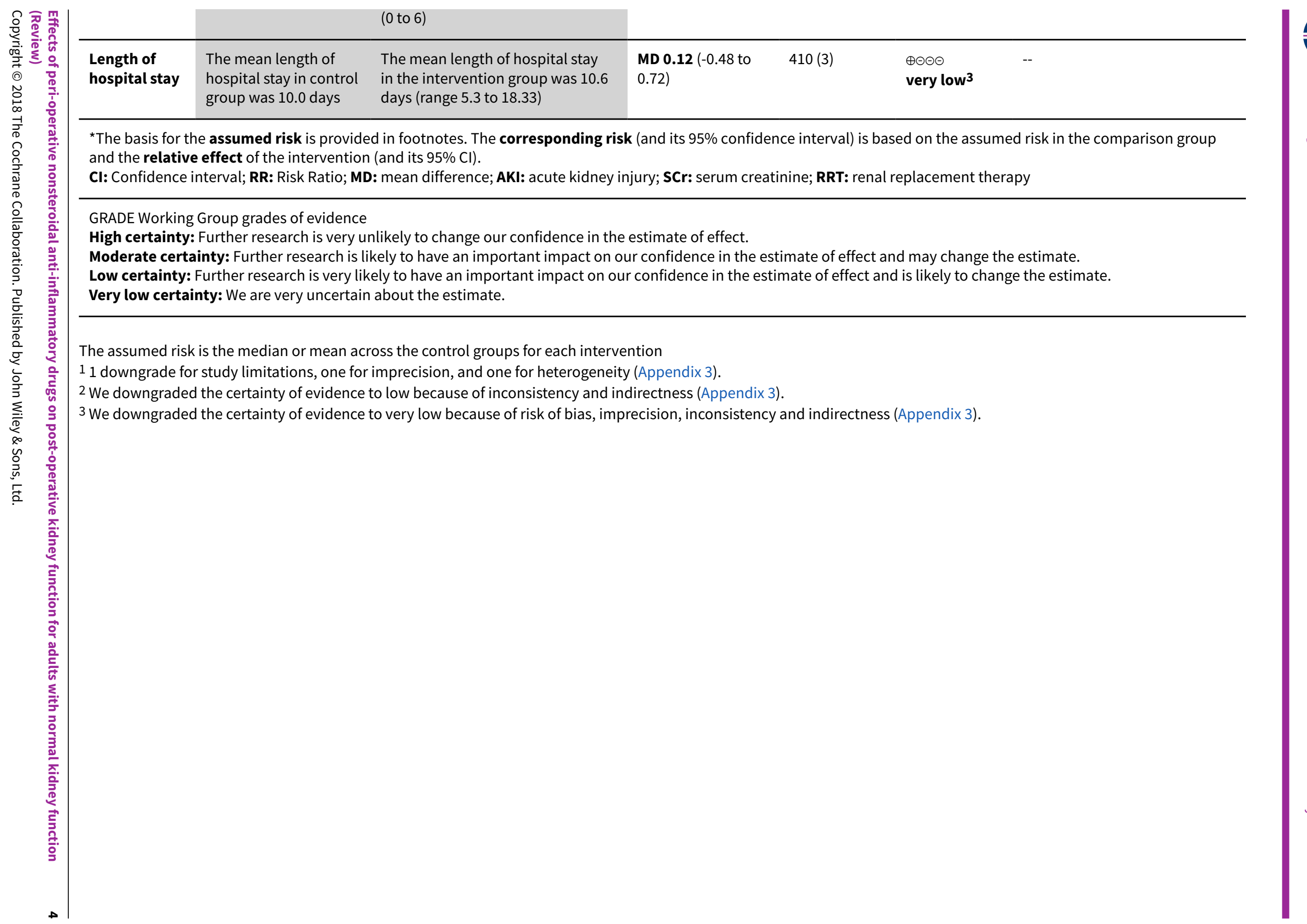


Figure 1. Meta-regression of change in post-operative serum creatinine (Analysis 2.1) by type of surgery, duration of NSAID use, and exclusion by age. Results are Beta with $95 \% \mathrm{Cl}$. A positive value for Beta indicates that a variable is associated with increased effect size.

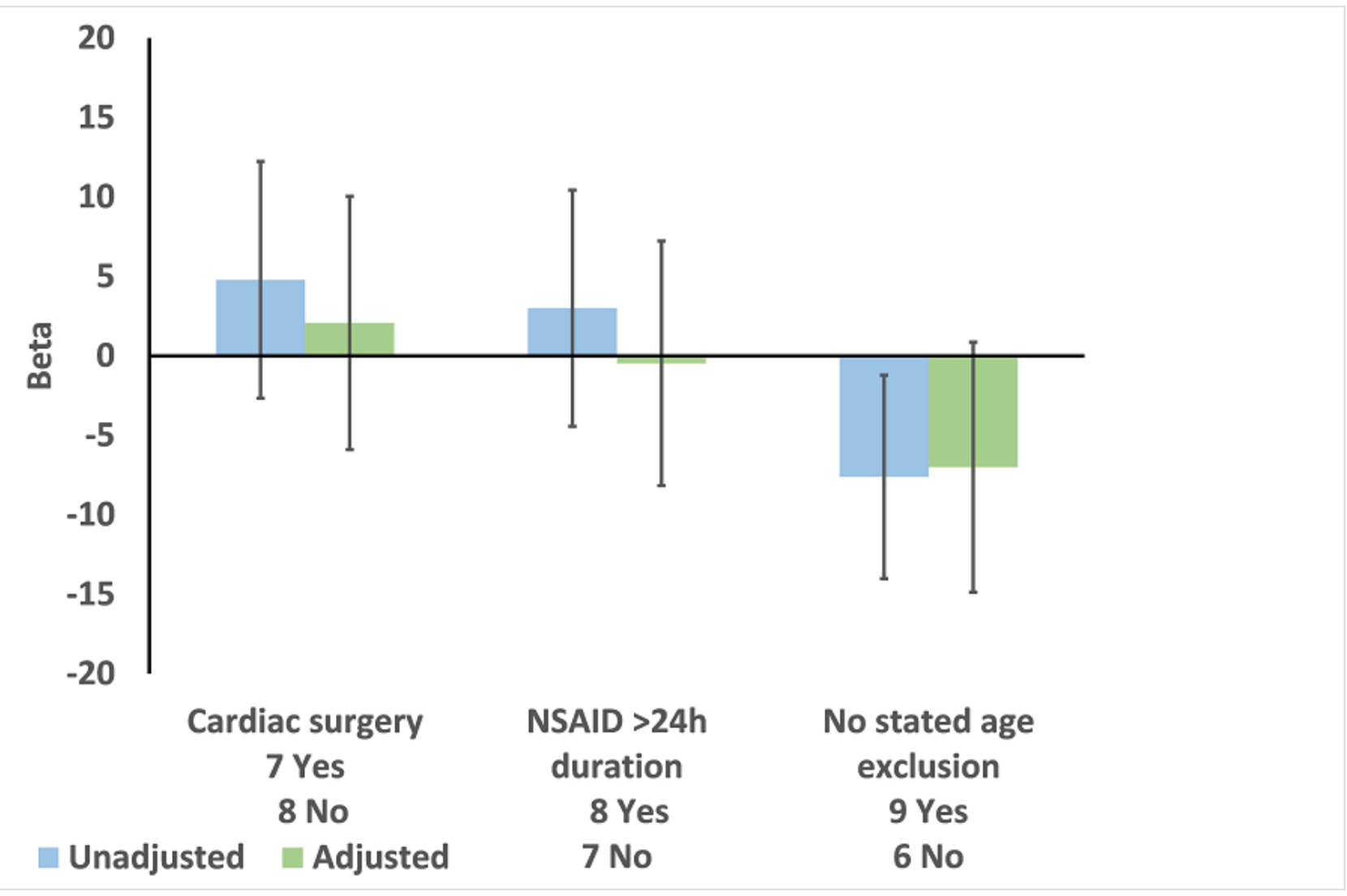




\section{B A C K G R O U N D}

\section{Description of the condition}

There is increasing evidence that acute kidney injury (AKI) is associated with both short- and long-term adverse consequences. These include increased length of hospital stay, death and future development of chronic kidney disease (CKD) even with small transient rises in serum creatinine (SCr) (Bucaloiu 2012; Chertow 2005; Coca 2012; Lassnigg 2004). Surgery is a leading cause of AKI in hospitalised patients (Carmichael 2003). There was previously significant variation in defining AKI. These included changes in $\mathrm{SCr}$, urine output and creatinine clearance $(\mathrm{CrCl})$. The Kidney Disease Improving Global Outcomes (KDIGO) definition has been universally accepted since 2012 KDIGO 2012.

Effective management of post-operative pain is extremely important. It facilitates early mobilisation thereby reducing hospital costs through shortened duration of hospital in-patient stay, reduces pulmonary and cardiovascular complications and risk of deep vein thrombosis. In addition, it impacts on quality of patient care by relieving suffering and distress and improving satisfaction. The major aim of post-operative pain management is providing adequate pain relief using the minimal possible dose thereby minimising adverse effects. Clinical guidelines for managing perioperative pain by the American Pain Society, the American Society of Regional Anesthesia and Pain Medicine, and the American Society of Anesthesiologists' Committee on Regional Anesthesia, Executive Committee, and Administrative Council were published in 2016 (Chou 2016). They recommend a multimodal approach to post-operative pain including the use of both nonselective nonsteroidal anti-inflammatory drugs; (NSAIDs) as well as selective NSAIDs (Cox-2 inhibitors). NSAIDs can affect the kidneys in a number of ways. This includes haemodynamically mediated AKI, electrolyte and acid-base disorders and acute interstitial nephritis. These adverse effects are thought to occur in $1 \%$ to $5 \%$ of all patients using NSAIDs (Whelton 1999).

\section{Description of the intervention}

NSAIDs inhibit prostaglandin synthesis by inhibiting cyclooxygenase- 1 (Cox-1) and cyclooxygenase -2 (Cox-2). Cox-1 is expressed in most tissues regulating normal cellular processes such as gastric cytoprotection, vascular homeostasis, platelet aggregation and kidney function. Cox-2 is expressed in brain, kidney and bone. Most traditional NSAIDs are non-selective inhibitors of both Cox-1 and Cox-2. Selective Cox-2 inhibitors include celecoxib, rofecoxib and valdecoxib.

Cyclooxygenases are produced at multiple sites within the kidney including glomerular and vascular endothelium, medullary and cortical collecting tubules and medullary interstitial cells. Cox-1 is expressed in most tissues and Cox-2 is expressed at low levels increasing with stimulation such as inflammation. Renal prostaglandins are primarily vasodilators in the kidneys. Under normal circumstances, renal prostaglandins do not contribute to regulation of kidney perfusion but in the setting of hypotension and reduced kidney perfusion from vasoconstriction prostaglandin synthesis is increased to maintain kidney perfusion and minimize ischaemia. Other kidney effects of prostaglandins include increased renin secretion, antagonism of anti-diuretic hormone effects and increased sodium excretion.

\section{How the intervention might work}

The use of both non-selective and selective NSAIDs for postoperative pain has been evaluated in a number of Cochrane reviews. A single dose of ibuprofen lead to at least $50 \%$ pain relief in approximately half of patients with moderate to severe postoperative pain. Adverse effects were similar to placebo (Derry 2009). Aspirin was found to confer a $50 \%$ or greater reduction in pain in $39 \%$ of those with moderate to severe pain, compared with $15 \%$ of those in the placebo group. Adverse events were similar for those taking a lower dose aspirin (600 mg or $650 \mathrm{mg}$ ). However, higher dose aspirin (900 mg to $1000 \mathrm{mg}$ ) experienced adverse events at more than twice the rate of patients receiving placebo ( $26 \%$ versus 12\%) (Derry 2012a). The use of a single dose of the Cox- 2 inhibitor celecoxib in the treatment of acute post-operative pain showed that $33 \%$ of patients receiving celecoxib $200 \mathrm{mg}$, and $44 \%$ receiving 400 $\mathrm{mg}$, experienced at least $50 \%$ pain relief, compared with between $1 \%$ and $11 \%$ of patients receiving placebo. Adverse events were similar in the celecoxib and placebo groups (Derry 2012b).

Furthermore, there is evidence supporting the efficacy of NSAIDs for post-operative pain with studies demonstrating opioid sparing effects (McDaid 2010).

NSAIDs have the potential to adversely affect kidney function in the peri-operative setting. Pre-renal insults such as hypovolaemia or hypotension peri-operatively cause NSAID-induced inhibition of prostaglandin mediated afferent arteriolar dilatation leading to reduced glomerular perfusion. The risk of AKI with NSAIDs has led the Medicines and Healthcare Products Regulatory Agency to issue drug safety advice recommending that NSAIDs be avoided in patients with hypovolaemia (MHRA 2009). Other adverse events associated with NSAIDs include gastrointestinal bleeding and cardiovascular events. These were not examined in this review.

\section{Why it is important to do this review}

This is an update of a Cochrane review last published in 2007 (Lee 2007). This review showed that NSAIDs caused a clinically unimportant transient reduction in kidney function in the early post-operative period in patients with normal kidney function. Since its publication, a universal definition for AKI has been developed allowing a better understanding of its epidemiology and clinical significance (KDIGO 2012). Since the advent of the $\mathrm{KDIGO}$ definition for $\mathrm{AKI}$, there is increasing evidence of the adverse clinical and economic consequences of AKI. In addition, National Institute for Clinical Excellence (NICE) AKI guidance recommends the avoidance of NSAIDs in the post-operative period (Ftouh 2013).

It is therefore important to re-assess the renal safety of NSAIDs in the peri-operative period.

\section{O B JECT IVES}

This review looked at the effect of NSAIDs used in the peri-operative period on post-operative kidney function in patients with normal kidney function. 


\section{METHODS}

\section{Criteria for considering studies for this review}

Types of studies

All randomised controlled trials (RCTs) and quasi-RCTs (RCTs in which allocation to treatment was obtained by alternation, use of alternate medical records, date of birth or other predictable methods) looking at the use of NSAIDs versus placebo in the post-operative phase in adults with normal kidney function were included.

\section{Types of participants}

People of at least 18 years of age undergoing surgical procedures who were treated with NSAIDs or Cox-2 inhibitors with normal kidney function were included. Normal kidney function was defined as estimated glomerular filtration rate (eGFR) $>60$ $\mathrm{mL} / \mathrm{min} / 1.73 \mathrm{~mm}^{2}$ without other evidence of kidney disease (proteinuria, haematuria, genetic kidney disease or structural kidney abnormalities).

\section{Types of interventions}

All interventions comparing NSAID treatments including Cox-2 inhibitors versus placebo were considered. Variable doses, all routes of administration and variable indications for NSAID use were considered.

\section{Types of outcome measures}

The primary endpoint was AKI. Studies measuring $\mathrm{SCr}$ and urine output in the post-operative phase were also considered. The secondary outcomes of length of hospital stay, death and requirement of renal replacement therapy (RRT) were documented when available.

\section{Primary outcomes}

The primary outcome was $A K I$ as defined by KDIGO which is based on SCr or urine output (KDIGO 2012). Change in SCr and urine output were also considered using the highest post-operative creatinine or lowest post-operative urine volume. These were analysed separately.

\section{Secondary outcomes}

1. Need for RRT

2. Death (all causes)

3. Length of hospital stay

\section{Search methods for identification of studies}

\section{Electronic searches}

We searched the Cochrane Kidney and Transplant Specialised Register up to 4 January 2018 through contact with the Information Specialist using search terms relevant to this review. The Cochrane Kidney and Transplant Specialised Register contains studies identified from several sources.

1. Monthly searches of the Cochrane Central Register of Controlled Trials (CENTRAL)

2. Weekly searches of MEDLINE OVID SP

3. Handsearching of kidney-related journals and the proceedings of major kidney conferences
4. Searching of the current year of EMBASE OVID SP

5. Weekly current awareness alerts for selected kidney and transplant journals

6. Searches of the International Clinical Trials Register (ICTRP) Search Portal and ClinicalTrials.gov.

Studies contained in the Specialised Register are identified through search strategies for CENTRAL, MEDLINE, and EMBASE based on the scope of Cochrane Kidney and Transplant. Details of these strategies, as well as a list of handsearched journals, conference proceedings and current awareness alerts, are available in the Specialised Register section of information about Cochrane Kidney and Transplant.

See Appendix 1 for search terms used in strategies for this review.

\section{Searching other resources}

1. Reference lists of review articles, relevant studies and clinical practice guidelines.

2. Letters seeking information about unpublished or incomplete studies to investigators known to be involved in previous studies.

\section{Data collection and analysis}

\section{Selection of studies}

The search strategy described was used to obtain titles and abstracts of studies relevant to the review. The titles and abstracts were screened independently by two authors, who discarded studies that were not applicable, however studies and reviews that might include relevant data or information on studies were retained initially. Two authors independently assessed retrieved abstracts and, if necessary the full text, of these studies to determine which studies satisfied the inclusion criteria.

\section{Data extraction and management}

Data extraction was carried out independently by two authors using standard data extraction forms. Studies reported in nonEnglish language journals were translated before assessment. Where more than one publication of one study existed, reports were grouped together and the publication with the most complete data were used in the analyses. Data extracted included study design, inclusion and exclusion criteria, patient numbers and characteristics and treatment regimen. For outcomes of interest (AKI, serum, creatinine, urine output, death, need for RRT and length of hospital stay), the raw data were extracted using mean, median and standard deviations for continuous outcomes, and event rate for dichotomous outcomes. Where data were collected at more than one time-point, these were all extracted. Peak SCr and lowest urine volume were used for the analyses.

\section{Assessment of risk of bias in included studies}

The following items were independently assessed by two authors using the risk of bias assessment tool (Higgins 2011) (see Appendix 2).

- Was there adequate sequence generation (selection bias)?

- Was allocation adequately concealed (selection bias)?

Effects of peri-operative nonsteroidal anti-inflammatory drugs on post-operative kidney function for adults with normal kidney function 
- Was knowledge of the allocated interventions adequately prevented during the study?

* Participants and personnel (performance bias)

* Outcome assessors (detection bias)

- Were incomplete outcome data adequately addressed (attrition bias)?

- Are reports of the study free of suggestion of selective outcome reporting (reporting bias)?

- Was the study apparently free of other problems that could put it at a risk of bias?

In each domain, studies were labelled as low, high or unclear risk of bias with consideration given to the presence or absence of sufficient information to make a determination. Reasons for assessment were documented (See Characteristics of included studies), and a risk of bias summary is presented.

\section{Measures of treatment effect}

For the dichotomous outcomes (presence of AKI, need for RRT and death), results were expressed as risk ratio (RR) with 95\% confidence intervals $(\mathrm{Cl})$. Continuous scales of measurement such as mean difference (MD) and $95 \% \mathrm{Cl}$ was used to assess the effects of treatment for change in $\mathrm{SCr}$ and length of hospital stay. $\mathrm{SCr}$ was converted to standardised units $(\mu \mathrm{mol} / \mathrm{L})$ and peak post-operative creatinine was used when more than one postoperative creatinine was reported. Mean change in $\mathrm{SCr}$ was not given in studies and so the correlation coefficient between pre and post-operative measures were not known. We therefore assumed a correlation coefficient of 0.50 (Follmann 1992). A sensitivity analysis was carried out assuming zero correlation. The standard deviation between pre and post-operative measures for each treatment group was estimated using a method outlined in the Cochrane Collaboration Handbook. When the median and interquartile range were reported, we assumed that the mean was equivalent to the median and estimated the standard deviation to be the interquartile range/1.35 (O'Rourke 2002). Standardised mean difference (SMD) was used for urine output as different scales were used. Lowest post-operative urine output was used when more than one time point was measured.

In studies comparing multiple different NSAIDs or varying dosing regimens, the dose or dug with the greatest adverse effect on kidney function was included in the analysis.

\section{Unit of analysis issues}

Studies with non-standard designs, such as cross-over studies and cluster-randomised studies were not included in this review.

\section{Dealing with missing data}

We did not contact any authors as the required information was present in the studies. Evaluation of important numerical data such as screened, randomised patients as well as intentionto-treat, as-treated and per-protocol population was carefully performed. Attrition rates, for example drop-outs, losses to followup and withdrawals were investigated. Issues of missing data and imputation methods (for example, last-observation-carriedforward) were critically appraised (Higgins 2011).

\section{Assessment of heterogeneity}

Heterogeneity was analysed using a $\mathrm{Chi}^{2}$ test on $\mathrm{N}-1$ degrees of freedom, with an alpha of 0.05 used for statistical significance and with the $1^{2}$ test (Higgins 2003). $\left.\right|^{2}$ values of $25 \%, 50 \%$ and $75 \%$ correspond to low, medium and high levels of heterogeneity.

\section{Assessment of reporting biases}

Funnel plots were used to assess for the potential existence of small study bias (Higgins 2011).

\section{Data synthesis}

Data were pooled using the random-effects model but the fixedeffect model was also be used to ensure robustness of the model chosen and susceptibility to outliers.

\section{Subgroup analysis and investigation of heterogeneity}

Meta-regression was carried out to investigate possible explanations for heterogeneity of effects, including type of surgery (cardiac versus other), duration of NSAID therapy ( $>24 \mathrm{~h}$ versus $<24 \mathrm{~h}$ ) and whether age was an exclusion criterion (no versus yes) as potential explanatory variables. Meta-regression used standard weighted (by standard error of estimate) linear regression in IBM SPSS Statistics 22.

\section{Sensitivity analysis}

We planned to perform sensitivity analyses if there were sufficient studies identified, in order to explore the influence of the following factors on effect size.

- Repeating the analysis excluding unpublished studies

- Repeating the analysis taking account of risk of bias, as specified

- Repeating the analysis excluding any very long or large studies to establish how much they dominate the results

- Repeating the analysis excluding studies using the following filters: diagnostic criteria, language of publication, source of funding (industry versus other), and country.

We were only able to investigate the influence of risk of bias on effect size due to the number of studies identified. The analysis was repeated excluding studies with high risk of bias, attrition bias or high risk of bias or attrition bias.

\section{'Summary of findings' tables}

We presented the main results of the review in 'Summary of findings' tables. These tables present key information concerning the quality of the evidence, the magnitude of the effects of the interventions examined, and the sum of the available data for the main outcomes (Schünemann 2011a). The 'Summary of findings' tables also include an overall grading of the evidence related to each of the main outcomes using the GRADE (Grades of Recommendation, Assessment, Development and Evaluation) approach (GRADE 2008). The GRADE approach defines the quality of a body of evidence as the extent to which one can be confident that an estimate of effect or association is close to the true quantity of specific interest. The quality of a body of evidence involves consideration of within-trial risk of bias (methodological quality), directness of evidence, heterogeneity, precision of effect estimates and risk of publication bias (Schünemann 2011b). We presented 
the following outcomes in Summary of findings for the main comparison.

- AKI within 30 days of surgery

- Mean difference in $\mathrm{SCr}$ increase in $\mu \mathrm{mol} / \mathrm{L}$ within 30 days of surgery

- RRT within 30 days of surgery

- Death (all causes)

- Length of hospital stay (days)

\section{RES U L T S}

\section{Description of studies}

See Characteristics of included studies; Characteristics of excluded studies

Figure 2. Study flow diagram.

\section{Results of the search}

In total 659 records were identified through database searches, and two records were added through other means. Forty-five records were duplicates and were excluded. The titles and abstracts of the remaining 616 records were reviewed by two independent assessors and 52 records were deemed eligible for full text review. Nineteen records (21 studies) were excluded; details about the reason for exclusion can be found in the table Characteristics of excluded studies. The remaining 31 records (26 studies) were included (see Figure 2).

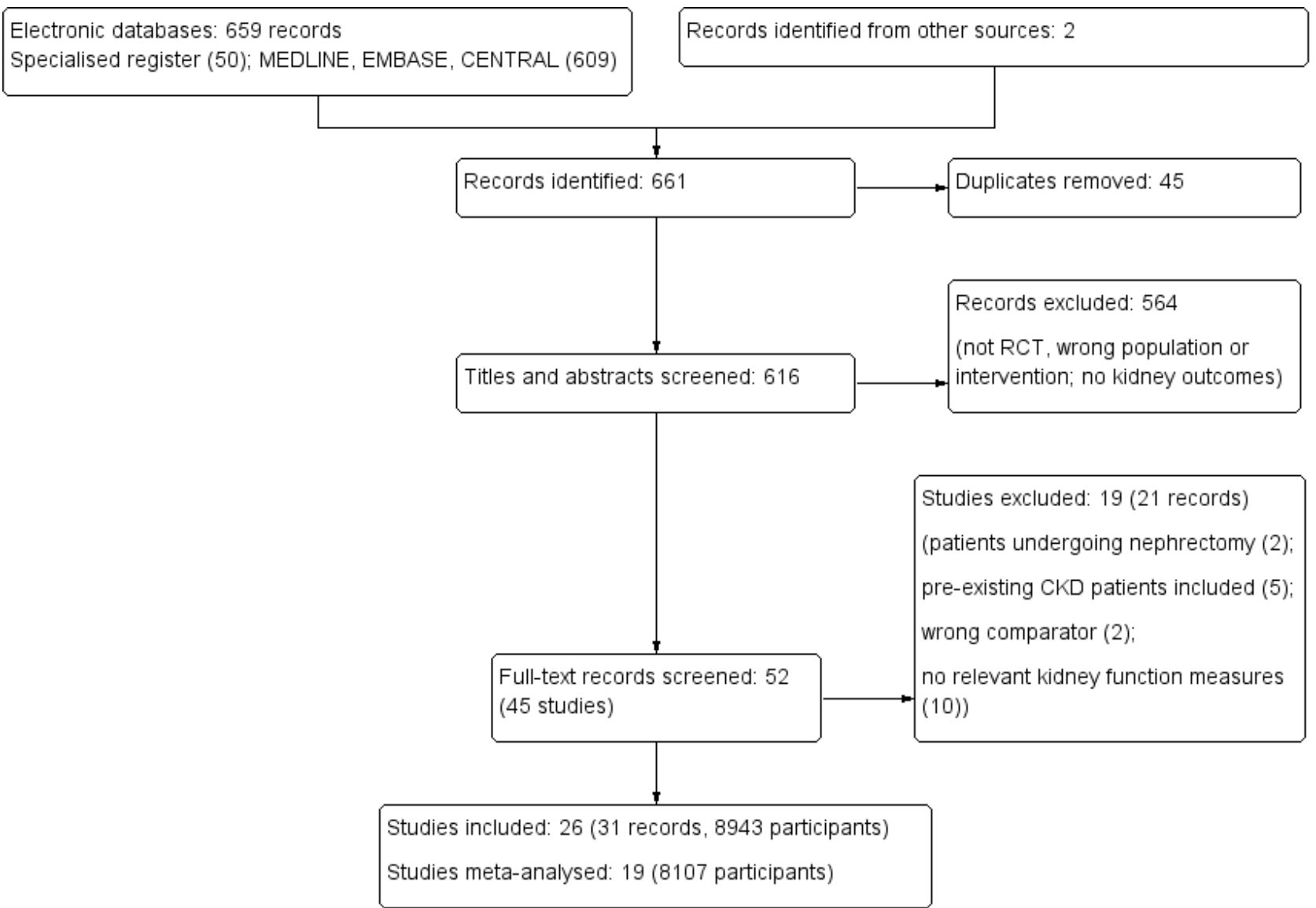

\section{Included studies}

Twenty-six studies (8943 patients) met our inclusion criteria. A detailed overview of all the included studies can be found in the Characteristics of included studies table. The studies were conducted between 1992 and 2017 and included adults with preserved kidney function prior to surgery. Of these, 19 (8107 participants) could be meta-analysed.

Six studies (Chow 2001; Castiglione 1997; Nuutinen 1991; Parker 1994; Ready 1994; Rao 2000) included in the previous version of this review (Lee 2007), were not included in our review. One study enrolled patients who underwent a nephrectomy (Chow 2001); one study used NSAID in both groups (Castiglione 1997); and four studies were excluded due to the absence of concise post-operative kidney outcomes in these studies (Nuutinen 1991; Parker 1994; Ready 1994; Rao 2000) - in line with the KDIGO diagnostic AKI criteria (KDIGO 2012).

Nine new studies (Eljezi 2017; Fayaz 2004; Koppert 2006; McCrory 2002; NAFARM 2011; Ott 2003; POISE-2 2013; Puolakka 2009; Rafiq 2014) were added to this review.

Effects of peri-operative nonsteroidal anti-inflammatory drugs on post-operative kidney function for adults with normal kidney function 


\section{Types of surgery}

Patients underwent various types of surgery: 13 studies reviewed patients undergoing open cardiac surgery (Eljezi 2017; Fayaz 2004; Hynninen 2000; Immer 2003; Khalil 2006a; Kulik 2004; McCrory 2002; NAFARM 2011; Ott 2003; Perttunen 1992; Perttunen 1999; Rafiq 2014; Rapanos 1999) and six studies reviewed abdominal or pelvic surgeries (Aitken 1992; Jones 2000; Power 1992; Puolakka 2009; Turner 1994; Varrassi 1994). The remainder of the studies reviewed patients undergoing orthopaedic, breast, and various other non-cardiac surgeries.

\section{Interventions}

NSAIDs included in the study were ketorolac (Aitken 1992; Laisalmi 2001a; Perttunen 1992; Perttunen 1999; Rafiq 2014; Varrassi 1994), indomethacin (Hynninen 2000; Rapanos 1999; Turner 1994), diclofenac (Fayaz 2004; Hynninen 2000; Immer 2003; Irwin 1995; Perttunen 1992; Perttunen 1999; Power 1992), aspirin (POISE-2 2013), ibuprofen (Brinkmann 1998; McCrory 2002; Rafiq 2014), naproxen (Kulik 2004), tenoxicam (Jones 2000; Slaven 1998), etodolac (Immer 2003), and ketoprofen (Eljezi 2017). Selective COX-2 inhibitors were used in four studies (Khalil 2006a; Koppert 2006; Ott 2003; Puolakka 2009).

Mode of delivery was via intravenous (IV) or intramuscular (IM) injection in 15 studies (Aitken 1992; Brinkmann 1998; Eljezi 2017; Jones 2000; Khalil 2006a; Koppert 2006; Kostamovaara 1996; Laisalmi 2001a; Perttunen 1992; Perttunen 1999; Power 1992; Puolakka 2009; Slaven 1998; Varrassi 1994). A combination of an IV bolus and oral maintenance dose was used by Ott 2003 and Rafiq 2014. The remaining studies used either oral, epidural or per rectum administration methods. Seven studies prescribed NSAIDs for the first post-operative day only (Fayaz 2004; Hynninen 2000; Irwin 1995; Laisalmi 2001a; Puolakka 2009; Rapanos 1999; Varrassi 1994). The median duration of post-operative NSAID exposure was 2 days (range 1 to 30 days).

\section{Measurement of primary outcomes}

One study defined AKI using the KDIGO definition (POISE-2 2013) and one using an elevation in $\mathrm{SCr}$ of $150 \%$ times the baseline
(NAFARM 2011). Creatinine was measured in 15 studies (Immer 2003; Koppert 2006; Kostamovaara 1996; Kulik 2004; Laisalmi 2001a; Ott 2003; Perttunen 1992; Perttunen 1999; POISE-2 2013; Power 1992; Puolakka 2009; Rafiq 2014; Rapanos 1999; Turner 1994; Varrassi 1994). A percentage change in creatinine from baseline was reported by Eljezi 2017. Change in urine output postoperatively was reported by seven studies (Aitken 1992; Eljezi 2017; Irwin 1995; Jones 2000; Laisalmi 2001a; Perttunen 1992; Perttunen 1999). Serum creatinine clearance was measured by one study (Brinkmann 1998) and urinary creatinine clearance by four studies (Khalil 2006a; Koppert 2006; McCrory 2002; Slaven 1998).

\section{Measurement of secondary outcomes}

Death (all causes) was reported by two studies (NAFARM 2011; Rafiq 2014); hospital stay by three studies (NAFARM 2011; Kulik 2004; Rafiq 2014), and two studies reported the need for RRT postoperatively (Rafiq 2014; POISE-2 2013).

\section{Excluded studies}

Nineteen studies (21 records) were excluded from this review. Details of the reason for exclusion for all of these are found in the Characteristics of excluded studies table.

Four studies were excluded due to the inclusion of patients with pre-existing CKD into their cohort (Cheruku 2004; Merry 2002; Nussmeier 2005; Nussmeier 2006). Two studies published results about kidney function after nephrectomy (Chow 2001; Grimsby 2012) and were deemed unsuitable for analysis in our review. Eleven studies were excluded due to lack of concise post-operative kidney outcomes (Daniels 2014; Fredman 1999; Hynes 2006; Leeson 2007; Ma 2015; Nuutinen 1991; Parker 1994; Rao 2000; Ready 1994; Southworth 2009; Varrassi 1999). Two studies were not suitable for inclusion in this review due to the lack of a suitable placebo group (Castiglione 1997; Doyle 1998).

\section{Risk of bias in included studies}

See Figure 3. 
Figure 3. Risk of bias graph: review authors' judgements about each risk of bias item presented as percentages across all included studies.

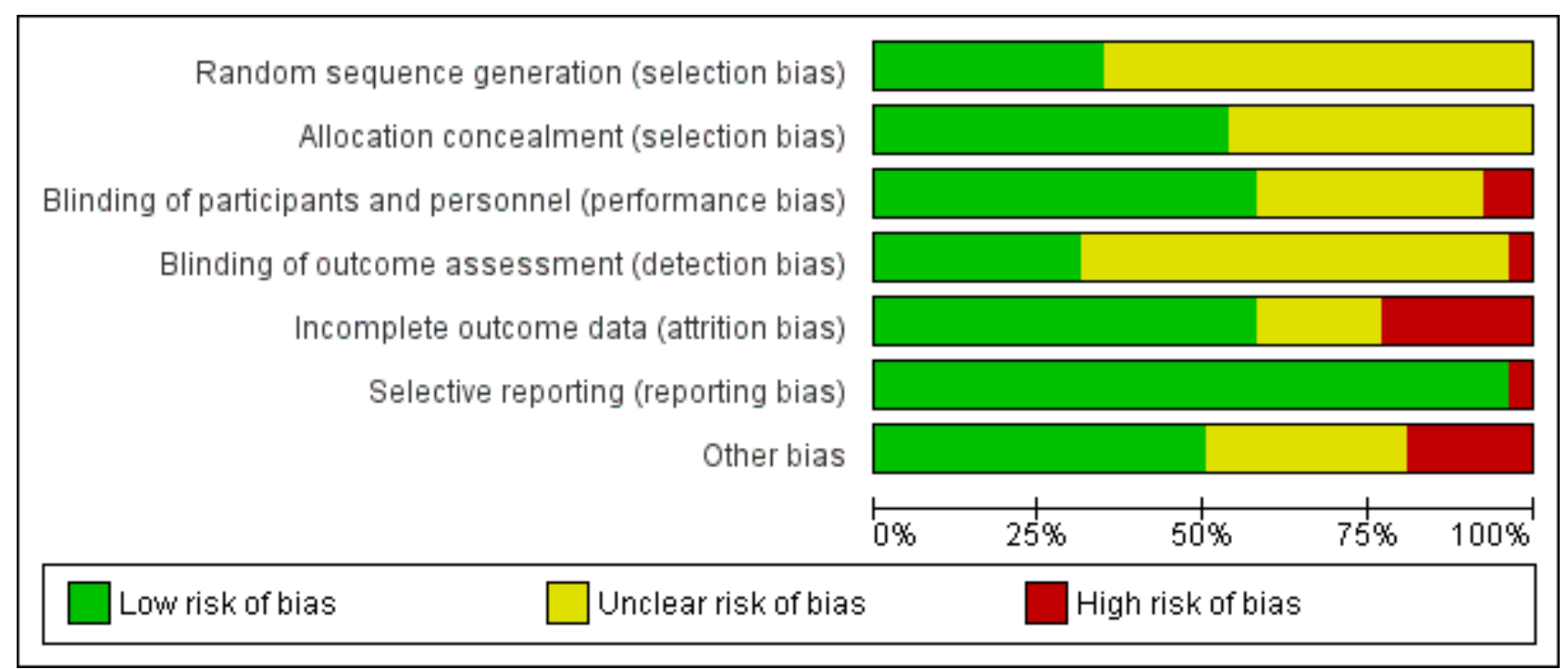

\section{Allocation}

\section{Random sequence generation}

Nine studies were assessed as low risk, with sufficient information about the sequence generation process (Fayaz 2004; Jones 2000; Khalil 2006a; Kulik 2004; NAFARM 2011; Perttunen 1999; POISE-2 2013; Puolakka 2009; Rapanos 1999). Most commonly described sequence generation method was computer software. In the remaining 17 studies randomisation was stated but no information was given about the method of sequence generation.

\section{Allocation concealment}

Fourteen studies described a randomisation method that was deemed adequate; investigators or participants did not know or have influence on the intervention group before entering the study (Eljezi 2017; Fayaz 2004; Hynninen 2000; Jones 2000; Khalil 2006a; Koppert 2006; Kulik 2004; NAFARM 2011; Perttunen 1999; POISE-2 2013; Puolakka 2009; Rafiq 2014; Rapanos 1999; Turner 1994). Most commonly used method was sequentially numbered opaque, sealed envelopes. The remaining 12 studies did not provide enough information to determine the method of allocation concealment.

\section{Blinding}

\section{Performance bias}

All studies mentioned blinding of participants, investigators or both in their methods section, however in nine studies insufficient information was provided regarding the methods by which this was achieved. For that reason those studies were assessed as unclear risk of performance bias due to the knowledge of the allocated interventions by participants and personnel during the study (Aitken 1992; Brinkmann 1998; Immer 2003; Irwin 1995; Kostamovaara 1996; Laisalmi 2001a; Ott 2003; Power 1992; Varrassi 1994). Two studies were open-label and were judged to be at high risk of bias (McCrory 2002; Rafiq 2014). The remaining 15 studies were judged to be a low risk of bias.

\section{Detection bias}

Seven studies were judged to be at low risk bias (Jones 2000; Kulik 2004; NAFARM 2011; Perttunen 1992; Perttunen 1999; POISE-2 2013; Turner 1994). One study was classed as high risk of detection bias (Rafiq 2014), and for the remaining 18 studies risk of detection bias was judged to be unclear.

\section{Incomplete outcome data}

Patient drop-out was reported in 16 studies.

- Protocol violation or equipment failure was the cause of the drop-out in seven studies (Aitken 1992; Irwin 1995; Koppert 2006; Ott 2003; Rafiq 2014; Rapanos 1999; Turner 1994).

- Side effects of the treatment or complications of the surgery was the cause for drop-out in five studies (Eljezi 2017: 3 patients dropped out due to complications of the surgery, reintubation and/or re-surgery; Kostamovaara 1996: 1 patient dropped out due to side effect of fentanyl administration, no side effects of the study drug ketorolac were identified; Kulik 2004: 2 patients in the naproxen group and 4 patients in the placebo group suffered from complications after surgery; Rafiq 2014: 21 patients had a prolonged stay in intensive care post surgery equally distributed between groups; Varrassi 1994: 5 patients withdrew due to re-laparotomy or inadequate pain control, equally distributed over the two groups).

- NAFARM 2011 reported death due to cardiac surgery as the cause of drop-out in five patients.

- Oliguria or rise in creatinine post operatively was identified as cause for withdrawal in six studies (Fayaz 2004; Hynninen 2000; Immer 2003; Kulik 2004; Power 1992; Rafiq 2014) affecting eight patients in total. This is a significant cause for concern as only three of these studies (Hynninen 2000; Immer 2003; Rafiq 2014) acknowledged the potential effect of the study medication on kidney function in their conclusion.

Six studies were deemed high risk of attrition bias due to missing data which potentially has a significant effect on the overall outcome of the study. Aitken 1992 failed to present the reader

Effects of peri-operative nonsteroidal anti-inflammatory drugs on post-operative kidney function for adults with normal kidney function 11

(Review)

Copyright @ 2018 The Cochrane Collaboration. Published by John Wiley \& Sons, Ltd. 
with a reason for missing urine output data in 15 of 61 patients, while $26 \%$ of patients were withdrawn from Ott 2003; mainly due adverse events. Oliguria and/or rise in creatinine post-operatively was identified as cause for withdrawal from the study in six studies. Four of these studies (Fayaz 2004; Immer 2003; Kulik 2004; Power 1992) were deemed high risk of bias since these patients who were particularly at risk of developing AKI (the primary outcome of this review) were withdrawn from the studies. Hynninen 2000 also withdrew one patient after one dose of indomethacin because of $\mathrm{SCr}$ increase $>20 \%$ post-operatively. This patient did not receive further NSAIDs as per protocol. This study was classed as low risk as the patient was not included in the post-operative outcome table and the plausible effect size of this one event is probably not enough to have a clinically relevant impact on observed effect size.

Fifteen studies were judged to be a low risk of attrition bias (Eljezi 2017; Hynninen 2000; Irwin 1995; Jones 2000; Khalil 2006a; Koppert 2006; Kostamovaara 1996; Laisalmi 2001a; NAFARM 2011; Perttunen 1999; POISE-2 2013; Puolakka 2009; Rafiq 2014; Rapanos 1999; Varrassi 1994). The risk of attrition bias was unclear in the remaining five studies.

\section{Selective reporting}

Twenty-five studies reported the outcomes that were prespecified in their methods. Eljezi 2017 failed to report the frequency of urinary output (4-hourly for 48 hours) and creatinine measurements (baseline, post-operative day 1 and 2) as they had set out to do in the methods section. Urinary output was documented at 48 hours only and a percentage change in $\mathrm{SCr}$ at 48 hours from baseline was reported. This study was classed as high risk for reporting bias as it is unclear whether a potential transient fall in urine output and rise in creatinine during the first post-operative day has occurred, which would significantly change the conclusion drawn from this report.

\section{Other potential sources of bias}

Eleven studies reported to have received either no funding or funding from a non-profit organisation and were therefore deemed at low risk of publication bias (Eljezi 2017; Kostamovaara 1996; Kulik 2004; Laisalmi 2001a; McCrory 2002; NAFARM 2011; Perttunen 1992; Perttunen 1999; Puolakka 2009; Rafiq 2014; Rapanos 1999). POISE-2 2013 used several sources of funding; firstly two large governmental non-profit organisations from Spain and Australia. Secondly an undefined amount of financial support as well as study drugs from a commercial body were disclosed. The authors state that the sponsors had no role in the design and conduct of the study, collection, management, analysis, review or approval of the manuscript; and decision to submit the manuscript for publication. Due to the combination of commercially as well as non commercially accrued funding sources used in this study, in combination with the extensive disclosure of the use of the commercially acquired funding, this study was classed as low risk. Slaven 1998 received the study drug and placebo as a gift from the manufacturer, however the study design and analysis of the results was independent of any company involvement and was judged to be at low risk of bias.

Six studies were classed as high risk of bias due to the use of commercial funding. An unknown quantity of financial support from a commercial body was received by three studies (Jones 2000; Khalil 2006a; Koppert 2006). Aitken 1992 received financial support as well as study drugs from a pharmaceutical company.
Commercially provided study drugs were used by Immer 2003. Other potential biases were unclear in the remaining eight studies.

\section{Effects of interventions}

See: Summary of findings for the main comparison Nonsteroidal anti-inflammatory drugs (NSAIDs) versus placebo or no treatment in the peri-operative period

See Summary of findings for the main comparison for main comparisons.

\section{Post-operative acute kidney injury}

One large study (6905 participants) POISE-2 2013 reported AKI defined by the KDIGO criteria and one smaller study (161 participants) NAFARM 2011 defined AKI as a rise of $\mathrm{SCr}$ of $150 \%$ times the baseline. The use of NSAIDs had uncertain effects on the incidence of AKI compared to placebo (Analysis 1.1 (2 studies, 7066 participants): RR $1.79,95 \% \mathrm{Cl} 0.40$ to $7.96 ; 1^{2}=$ $59 \%$; very low certainty evidence). The analysis was dominated by POISE-2 2013 with $70.4 \%$ of the weighting and medium level of heterogeneity. NAFARM 2011 was terminated early by the trial monitoring committee because of increased risk of AKI.

\section{Post-operative serum creatinine}

Change in $\mathrm{SCr}$ was reported in 15 studies. AKI is defined as peak post-operative $\mathrm{SCr}$ and so where creatinine was measured over several time points, peak $\mathrm{SCr}$ was used for the analysis. In addition, where several different NSAIDs or dosing regimens were compared in a study, the regime or drug with the greatest adverse effect on kidney function was included within the analysis. Ott 2003 defined kidney dysfunction as a creatinine value $>177 \mu \mathrm{mol} / \mathrm{L}$ and an increase of $62 \mu \mathrm{mol} / \mathrm{L}$ with an incidence of $2.6 \%$ in both groups. This study was not included in the pooled analysis due to the lack of absolute values.

Compared to placebo, NSAIDs may slightly increase serum $\mathrm{SCr}$ (Analysis 2.1 (15 studies, 794 participants): MD $3.23 \mu \mathrm{mol} / \mathrm{L}, 95 \% \mathrm{Cl}$ -0.80 to $7.26 ; 1^{2}=66 \%$; low certainty evidence). Heterogeneity was medium to high.

\section{Meta-regression of change in post-operative serum creatinine by pre-specified effect modifiers}

Of the 15 studies in the meta-analysis of change in post-operative $\mathrm{SCr}$ (Analysis 2.1), seven studies were in cardiac surgery, eight with $>24$ hours of NSAID use, and nine with no stated age exclusion (Table 1). As expected cardiac surgery and $>24$ hours of NSAID use were associated with a positive beta (greater effect size) in the meta-regression (Figure 1). In contrast, we expected that RCTs with no stated age exclusion would have greater effect size but beta was negative (lower effect size) for these RCTs in the univariate meta-regression (Figure 1). Multivariate analysis did not identify significant effect modifiers (Figure 1).

\section{Sensitivity analyses}

Exclusion of studies with an overall high risk of bias (Analysis 2.2), high risk of attrition bias (Analysis 2.3) and either high overall risk of bias or high risk of attrition bias (Analysis 2.4) reduced the effect estimate.

Effects of peri-operative nonsteroidal anti-inflammatory drugs on post-operative kidney function for adults with normal kidney function 


\section{Post-operative urine output}

Change in urine output was measured in seven studies. Eljezi 2017 measured urine output at 48 hours but did not report baseline urine output. Where urine output was measured over several time points, lowest post-operative urine output was used for the analysis. Urine output was measured as total volume, $\mathrm{mL} / \mathrm{min}$ and $\mathrm{mL} / \mathrm{kg} / \mathrm{h}$ therefore standardised mean difference (SMD) was used for pooling the data.

NSAIDs may make little or no difference to post-operative urine output compared to placebo (Analysis 3.1 ( 6 studies, 149 participants): SMD $-0.49,95 \% \mathrm{Cl}-1.21$ to $0.24 ;\left.\right|^{2}=77 \%$; low certainty evidence) Heterogeneity was high. The differences in units of measurements and time points when urine output was measured in the different studies rendered interpretation of these results difficult.

\section{Need for renal replacement therapy}

Two studies reported the need for RRT (POISE-2 2013; Rafiq 2014). It is uncertain whether NSAIDs leads to the need for RRT because the certainty of this evidence is very low (Analysis 4.1 (2 studies, 7056 participants): RR $1.57,95 \% \mathrm{Cl} 0.49$ to $5.07 ; \mathrm{I}^{2}=26 \%$ ). Heterogeneity was low.

\section{Death (all causes)}

Two studies reported death (NAFARM 2011; Rafiq 2014). It is uncertain whether NSAIDs leads to more deaths because the certainty of this evidence is very low. These were two small studies with a small number of events (Analysis 5.1 (2 studies, 312 participants): RR $1.44,95 \% \mathrm{Cl} 0.19$ to $11.12 ; \mathrm{I}^{2}=38 \%$ ) Heterogeneity was low to medium.

\section{Length of hospital stay}

Three studies examined length of hospital stay (NAFARM 2011; Kulik 2004; Rafiq 2014). It is uncertain whether NSAIDs result in a longer hospital stay because the certainty of this evidence is very low (Analysis 6.1 ( 3 studies, 410 participants): MD 0.12 days, $95 \% \mathrm{Cl}-0.48$ to $0.72 ; 12=24 \%)$. Heterogeneity was low.

\section{DISCUSSION}

\section{Summary of main results}

We included 26 eligible studies (8943 participants) examining the use of NSAIDs in the perioperative period in patients with normal kidney function. The primary outcome of AKI, defined by KDIGO creatinine-based criteria, was used in only two studies. Change in $\mathrm{SCr}$ was measured in 14 studies and urine output in seven. For the secondary outcomes, two studies examined RRT, two examined death, and two length of hospital stay. Type of surgery, duration of treatment and dosage varied among the studies. Kidney outcomes were secondary outcomes in 13 studies. Two studies examined the use of NSAIDs for indications other than analgesia (NAFARM 2011; POISE-2 2013) and the NSAID doses were lower than would be used as analgesia. Overall risk of bias was high in 17 , unclear in six studies and low in three studies. Overall NSAIDs had uncertain effects on the risk of post-operative AKI, may slightly increase post-operative $\mathrm{SCr}$, and it is uncertain whether NSAIDs leads to the need for RRT, death or increases the length of hospital stay (Summary of findings for the main comparison)
The two studies with AKI as a primary outcome were the largest studies in the review and had few exclusions (NAFARM 2011; POISE-2 2013). One study was stopped by the data monitoring committee because of increased risk of post-operative AKI in the NSAID group (NAFARM 2011). The indication for NSAID use was to reduce risk of post-operative atrial fibrillation. The dose of naproxen $(550 \mathrm{mg} / \mathrm{d}$ ) was below the lowest daily dose recommended for analgesia for osteoarthritis $(750 \mathrm{mg} / \mathrm{d}$; Chou 2011) and substantially lower than the dose of $1000 \mathrm{mg} / \mathrm{d}$ used for post-operative analgesia in another study in our review (Kulik 2004). The contrast between the results of NAFARM 2011 and Kulik 2004 is striking. Both studies used the same NSAID (naproxen) for the same duration (four days) in the same patient group (coronary artery bypass graft surgery). However, despite using a much lower dose of naproxen, NAFARM 2011 was stopped because of increased risk of post-operative AKI whereas Kulik 2004 reported that naproxen use was associated with a mean decrease in postoperative SCr. POISE-2 2013 aimed to reduce the risk of postoperative $\mathrm{AKI}$ in patients undergoing elective or emergency surgery and included 6905 patients from 22 countries. The aspirin group received $200 \mathrm{mg}$ on the day of surgery and then $100 \mathrm{mg} / \mathrm{d}$ for seven days, whereas the maximum recommended daily dose of aspirin is $4000 \mathrm{mg}$ (NICE 2017).

Compared to placebo, NSAIDs may slightly increase serum $\mathrm{SCr}$ (3.23 $\mu \mathrm{mol} / \mathrm{L}, 95 \% \mathrm{Cl}-0.80$ to 7.26 ). Studies displayed moderate to high heterogeneity with multiple different exclusion criteria (e.g. age, diabetes, heart failure, use of diuretics) and so were not representative of patients undergoing surgery. Three of these studies excluded patients if their creatinine rose post-operatively.

No reliable conclusions could be drawn from the studies examining urine output due to the differing units of measurements and measurement time points.

It is uncertain whether the use of NSAIDs leads to an increased need for RRT, more deaths, or increased length of hospital stay.

\section{Overall completeness and applicability of evidence}

There are significant limitations to this review. Most of the studies excluded patients with co-morbidities such as diabetes, heart, liver, or respiratory failure. The population studied was therefore highly selected and non-representative of the population of patients undergoing surgery in most hospitals. With the exception of one study (POISE-2 2013), the studies were small and heterogeneous examining various types of NSAIDs, various doses and different types of surgery. A further important limitation was that three studies (Fayaz 2004; Hynninen 2000; Immer 2003) excluded patients if their $\mathrm{SCr}$ rose post-operatively and one study (Power 1992) administered furosemide to patients if their post-operative urine output fell. This impacts on the outcomes of these studies as they included both $\mathrm{SCr}$ and urine output.

The largest study (POISE-2 2013) examined the kidney effects of aspirin for an indication other than analgesia in 6905 patients undergoing surgery. Types of surgery included major vascular, thoracic, urological, and gynaecological. Patients with co-morbidities such as diabetes and cardiovascular disease were included. There were also patients with CKD included. Patients received aspirin at very low dose $(100 \mathrm{mg} / \mathrm{d}$; NICE 2017) and was associated with an uncertain effect on post-operative AKI (Analysis 1.1) and RRT (Analysis 4.1). The risk difference for RRT was 3 patients

Effects of peri-operative nonsteroidal anti-inflammatory drugs on post-operative kidney function for adults with normal kidney function 
per 1000 treated $(95 \% \mathrm{Cl} 0$ to 6$)$. Inclusion of this large study impacted significantly on the findings of this review.

\section{Quality of the evidence}

We identified 26 eligible RCTs with 8835 participants examining the use of NSAIDs in the perioperative period in patients with normal kidney function. Risk of bias was high in 17 , unclear in 6 studies and low in 3 studies with high risk of attrition bias in 6 studies.

We have graded the evidence that NSAIDs increase the risk of post-operative AKI as very low certainty (Summary of findings for the main comparison). These were the largest RCTs in the review and both were low risk of bias (NAFARM 2011, POISE-2 2013). Importantly, both trials included patients with co-morbidities and both studies used NSAIDs at relatively low doses for non-analgesic indications. Our main concern was about the inconsistencies between the two studies. Risk of AKI in the control groups were completely different (1.2\% in NAFARM 2011 versus $12.3 \%$ in POISE-2 2013).

Figure 4. Funnel plot of comparison: 2.1 Mean difference in serum creatinine

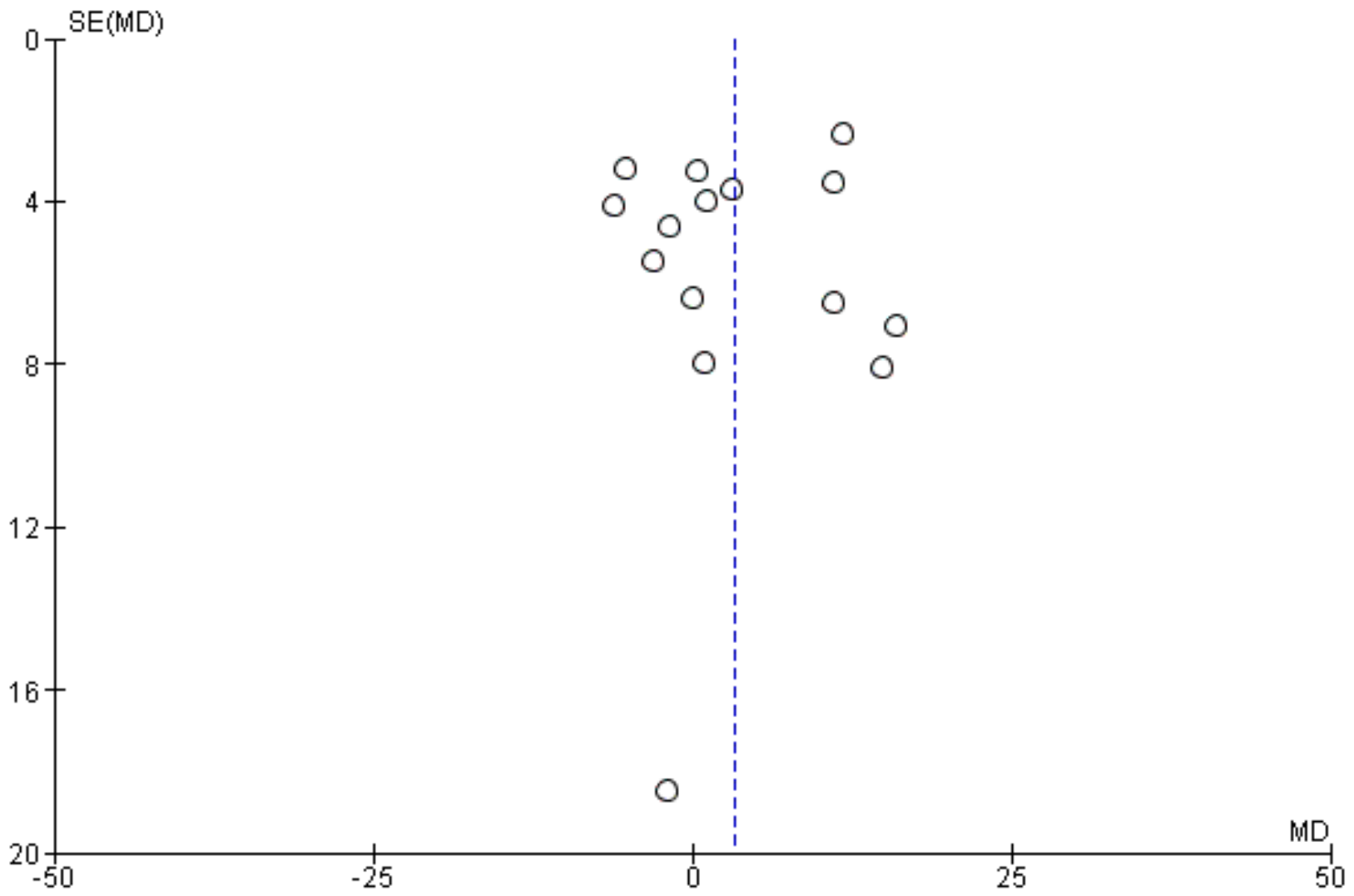

We were concerned that studies with high risk of bias would underestimate the effect of NSAIDs on post-operative kidney function. However, sensitivity analysis of post-operative $\mathrm{SCr}$ increase showed that exclusion of studies with high risk of overall bias or attrition bias reduced the study effects (Analysis 2.2; Analysis 2.3; Analysis 2.4).
We graded the evidence about increase in post-operative $\mathrm{SCr}$ as low certainty. The certainty of evidence was downgraded because of inconsistency (heterogeneity was not adequately explained by prespecified effect modifiers) and indirectness (studies had multiple exclusion criteria with the patients included in the RCTs likely to be different from those in routine care). The results of Kulik 2004 (decrease in $\mathrm{SCr}$ associated with naproxen for 5 days after cardiac surgery) are in stark contrast to the results of NAFARM 2011 (study stopped because of excess risk of AKI associated with a lower dose of naproxen for 5 days after cardiac surgery). There was potential for publication bias as studies were small and commercially funded. However, the Funnel Plot was symmetrical (Figure 4). For the outcome of RRT, certainty of evidence was very low. This was downgraded because of imprecision, inconsistency and publication bias. There was imprecision due to low number of events, inconsistency as the risk of RRT was completely different in the two control groups (0.3\% in NAFARM 2011 versus $2.7 \%$ in Rafiq 2014) and publication bias as one of the two studies was small and commercially funded. 
less likely. A strength of this review is that we included studies defining AKI using the KDIGO definition KDIGO 2012.

\section{Agreements and disagreements with other studies or reviews}

Lee 2007 concluded that NSAIDs caused a clinically unimportant reduction in kidney function on the first post-operative day in patients with normal kidney function. They examined several surrogate measures for kidney function including urinary sodium and $\mathrm{CrCl}$. $\mathrm{CrCl}$ estimations are based on steady state measurements and so are inaccurate in AKI with fluctuating creatinine levels. Lee 2007 found a reduction in $\mathrm{CrCl}$ of $16 \mathrm{~mL} / \mathrm{min}(95 \% \mathrm{Cl} 5$ to 28$)$ in patients treated with NSAIDs. Since this review, there is now a universally agreed definition for AKI based on SCr or urine output which has been adopted by KDIGO (KDIGO 2012). The studies included in the previous review also excluded patients with comorbidities and so these results cannot be applied to the general population undergoing surgery as many these will be older patients with co-morbidities.

\section{AUTHORS' CONCLUSIONS}

\section{Implications for practice}

There is a lack of evidence about the safety of NSAIDs used in the peri-operative period in all patients; patients with co-morbidities were excluded and NSAIDs had uncertain effects on AKI and the need for RRT. Whilst, NSAIDs may be safely used in fit, healthy patients, care should be employed in high risk patients. We were unable to identify which patients are at risk based on the results of this review and so clinical judgement should be employed based on the individual and alternative analgesic strategies may need to be employed in selected cases.

\section{Implications for research}

Our analysis was limited to small studies excluding patients with co-morbidities. Several of the studies were designed to investigate AKI as a secondary outcome and used varying definitions for AKI. The indication for NSAID was not analgesia in all of the studies and the doses varied. Several studies excluded patients if their creatinine rose post-operatively or their urine output fell. Further larger studies using the KDIGO definition for AKI including patients with co-morbidities are required to confirm our findings.

\section{ACK N O WLEDGEMENTS}

We would like to thank the referees for their feedback and advice during the preparation of this review. We would like to thank Cochrane and Kidney Transplant's Information Specialist for their help. 


\section{R E F E R E N C E S}

\section{References to studies included in this review}

Aitken 1992 \{published data only\}

Aitken HA, Burns JW, McArdle CS, Kenny GN. Effects of ketorolac trometamol on renal function. British Journal of Anaesthesia 1992;68(5):481-5. [MEDLINE: 1642936]

\section{Brinkmann 1998 \{published data only\}}

Brinkmann A, Seeling W, Wolf CF, Kneitinger E, Vogt N, Steinbach G, et al. Ibuprofen does not impair renal function in patients undergoing infrarenal aortic surgery with epidural anaesthesia. Intensive Care Medicine 1998;24(4):322-8. [MEDLINE: 9609409]

\section{Eljezi 2017 \{published data only\}}

Eljezi V, Biboulet C, Boby H, Schoeffler P, Pereira B, Duale C. The dose-dependent effects of ketoprofen on dynamic pain after open heart surgery. Pain Physician 2017;20(6):509-20. [MEDLINE: 28934782]

\section{Fayaz 2004 \{published data only\}}

Fayaz MK, Abel RJ, Pugh SC, Hall JE, Djaiani G, Mecklenburgh JS. Opioid-sparing effects of diclofenac and paracetamol lead to improved outcomes after cardiac surgery. Journal of Cardiothoracic \& Vascular Anaesthesia 2004;18(6):742-7. [MEDLINE: 15650984]

\section{Hynninen 2000 \{published data only\}}

Hynninen MS, Cheng DC, Hossain I, Carroll J, Aumbhagavan SS, Yue R, et al. Non-steroidal anti-inflammatory drugs in treatment of postoperative pain after cardiac surgery. Canadian Journal of Anaesthesia 2000;47(12):1182-7. [MEDLINE: 11132739]

\section{Immer 2003 \{published data only\}}

Immer FF, Immer-Bansi AS, Trachsel N, Berdat PA, Eigenmann V, Curatolo $\mathrm{M}$, et al. Pain treatment with a COX-2 inhibitor after coronary artery bypass operation: a randomized trial. Annals of Thoracic Surgery 2003;75(2):490-5. [MEDLINE: 12607659]

\section{Irwin 1995 \{published data only\}}

Irwin MG, Roulson CJ, Jones RD, Cheng IK, Visram AR, Chan YM. Peri-operative administration of rectal diclofenac sodium. The effect on renal function in patients undergoing minor orthopaedic surgery. European Journal of Anaesthesiology 1995;12(4):403-6. [MEDLINE: 7588670]

\section{Jones 2000 \{published data only\}}

Jones RD, Endre Z, Miles W, Prankerd R, Chilvers M, Willgoss D. Tenoxicam i.v. for major gynaecological surgery--effects on renal function. Anaesthesia \& Intensive Care 2000;28(5):501-9. [MEDLINE: 11094664]

Jones RD, Miles W, Prankerd R, Lang C, Chilvers M, Lo SK. Tenoxicam i.v. in major gynaecological surgery-pharmacokinetic, pain relief and haematological effects. Anaesthesia \& Intensive Care 2000;28(5):491-500. [MEDLINE: 11094663]
Khalil 2006a \{published data only\}

Khalil MW, Chaterjee A, MacBryde G, Sarkar PK, Marks RR. Single dose parecoxib significantly improves ventilatory function in early extubation coronary artery bypass surgery: a prospective randomized double blind placebo controlled trial. British Journal of Anaesthesia 2006;96(2):171-8. [MEDLINE: 16361300]

\section{Koppert 2006 \{published data only\}}

Koppert W, Frotsch K, Huzurudin N, Boswald W, Griessinger N, Weisbach $\mathrm{V}$, et al. The effects of paracetamol and parecoxib on kidney function in elderly patients undergoing orthopedic surgery. Anesthesia \& Analgesia 2006;103(5):1170-6. [MEDLINE: 17056950]

\section{Kostamovaara 1996 \{published data only\}}

Kostamovaara PA, Laitinen JO, Nuutinen LS, Koivuranta MK. Intravenous ketoprofen for pain relief after total hip or knee replacement. Acta Anaesthesiologica Scandinavica 1996;40(6):697-703. [MEDLINE: 8836264]

Kulik 2004 \{published and unpublished data\}

Kulik A, Ruel M, Bourke ME, Sawyer L, Penning J, Nathan HJ, et al. Postoperative naproxen after coronary artery bypass surgery: a double-blind randomized controlled trial. European Journal of Cardio-Thoracic Surgery 2004;26(4):694-700. [MEDLINE: 15450559]

\section{Laisalmi 2001a \{published data only\}}

Laisalmi M, Eriksson H, Koivusalo AM, Pere P, Rosenberg P, Lindgren L. Ketorolac is not nephrotoxic in connection with sevoflurane anesthesia in patients undergoing breast surgery. Anesthesia \& Analgesia 2001;92(4):1058-63. [MEDLINE: $11273951]$

Laisalmi M, Teppo AM, Koivusalo AM, Honkanen E, Valta P, Lindgren $\mathrm{L}$. The effect of ketorolac and sevoflurane anesthesia on renal glomerular and tubular function. Anesthesia \& Analgesia 2001;93(5):1210-3. [MEDLINE: 11682399]

McCrory 2002 \{published data only\}

McCrory C, Diviney D, Moriarty J, Luke D, Fitzgerald D. Comparison between repeat bolus intrathecal morphine and an epidurally delivered bupivacaine and fentanyl combination in the management of post-thoracotomy pain with or without cyclooxygenase inhibition. Journal of Cardiothoracic \& Vascular Anesthesia 2002;16(5):607-11. [MEDLINE: 12407615]

\section{NAFARM 2011 \{published data only\}}

Horbach SJ, Lopes RD, da C Guaragna JC, Martini F, Mehta RH, Petracco JB, et al. Naproxen as prophylaxis against atrial fibrillation after cardiac surgery: the NAFARM randomized trial. American Journal of Medicine 2011;124(11):1036-42. [MEDLINE: 22017782]

\section{Ott 2003 \{published data only\}}

Ott E, Nussmeier NA, Duke PC, Feneck RO, Alston RP, Snabes MC, et al. Efficacy and safety of the cyclooxygenase 2 inhibitors parecoxib and valdecoxib in patients undergoing coronary artery bypass surgery. Journal of Thoracic \&

Effects of peri-operative nonsteroidal anti-inflammatory drugs on post-operative kidney function for adults with normal kidney function 
Cardiovascular Surgery 2003;125(6):1481-92. [MEDLINE: 12830070]

\section{Perttunen 1992 \{published data only\}}

Perttunen K, Kalson E, Heinonen J, Salo J. IV diclofenac in post-thoracotomy pain. British Journal of Anaesthesia 1992;68(5):474-80. [MEDLINE: 1642935]

\section{Perttunen 1999 \{published data only\}}

Perttunen K, Nilsson E, Kalso E. I.V. diclofenac and ketorolac for pain after thoracoscopic surgery. British Journal of Anaesthesia 1999;82(2):221-7. [MEDLINE: 10364998]

\section{POISE-2 2013 \{published data only\}}

Chludzinski A, Irani C, Mascha EJ, Kurz A, Devereaux PJ, Sessler DI. Protocol understanding and anxiety in perioperative clinical trial patients approached for consent on the day of surgery. Mayo Clinic Proceedings 2013;88(5):446-54. [MEDLINE: 23639498]

Devereaux PJ, POISE-2 Investigators. Rationale and design of the PeriOperative ISchemic Evaluation-2 (POISE-2) trial: an international $2 \times 2$ factorial randomized controlled trial of acetyl-salicylic acid vs. placebo and clonidine vs. placebo in patients undergoing noncardiac surgery. American Heart Journal 2014;167(6):804-9. [MEDLINE: 24890528]

Garg AX, Kurz A, Sessler DI, Cuerden M, Robinson A, Mrkobrada $\mathrm{M}$, et al. Aspirin and clonidine in non-cardiac surgery: acute kidney injury substudy protocol of the Perioperative Ischaemic Evaluation (POISE) 2 randomised controlled trial. BMJ Open 2014;4(2):e004886. [MEDLINE: 24568963]

Garg AX, Kurz A, Sessler DI, Cuerden M, Robinson A, Mrkobrada $\mathrm{M}$, et al. Perioperative aspirin and clonidine and risk of acute kidney injury: a randomized clinical trial. JAMA 2014;312(21):2254-64. [MEDLINE: 25399007]

\section{Power 1992 \{published data only\}}

Power I, Cumming AD, Pugh GC. Effect of diclofenac on renal function and prostacyclin generation after surgery. British Journal of Anaesthesia 1992;69(5):451-6. [MEDLINE: 1467074]

\section{Puolakka 2009 \{published data only\}}

Puolakka PA, Rintala S, Yli-Hankala A, Luukkaala T, Harmoinen A, Lindgren $L$, et al. The effect of parecoxib on kidney function at laparoscopic hysterectomy. Renal Failure 2009;31(4):284-9. [MEDLINE: 19462277]

\section{Rafiq 2014 \{published data only\}}

Rafiq S, Steinbruchel DA, Wanscher MJ, Andersen LW, Navne A, Lilleoer NB, et al. Multimodal analgesia versus traditional opiate based analgesia after cardiac surgery, a randomized controlled trial. Journal of Cardiothoracic Surgery 2014;9:52. [MEDLINE: 24650125]

\section{Rapanos 1999 \{published data only\}}

Rapanos T, Murphy P, Szalai JP, Burlacoff L, Lam-McCulloch J, Kay J. Rectal indomethacin reduces postoperative pain and morphine use after cardiac surgery. Canadian Journal of Anaesthesia 1999;46(8):725-30. [MEDLINE: 10451130]

\section{Slaven 1998 \{published data only\}}

Slaven GM, Walker RJ, Zacharias M, Fawcett JP, Hodgson BF. Tenoxicam does not alter renal function during anaesthesia in normal individuals. Australian \& New Zealand Journal of Medicine 1998;28(6):772-6. [MEDLINE: 9972405]

\section{Turner 1994 \{published data only\}}

Turner GA, Gorringe J. Indomethacin as adjunct analgesia following open cholecystectomy. Anaesthesia \& Intensive Care 1994;22(1):25-9. [MEDLINE: 8160944]

\section{Varrassi 1994 \{published data only\}}

Varrassi G, Panella L, Piroli A, Marinangeli F, Varrassi S, Wolman I, et al. The effects of perioperative ketorolac infusion on postoperative pain and endocrine-metabolic response. Anesthesia \& Analgesia 1994;78(3):514-9. [MEDLINE: 8109770]

\section{References to studies excluded from this review}

Castiglione 1997 \{published data only\}

Castiglione G, Hauf ME, Panascia E, Scuderi C, Crimi G. Does the preoperative administration of ketorolac improve postoperative analgesia? [La somministrazione preoperatoria di ketorolac migliora l'analgesia postoperatoria?]. Minerva Anestesiologica 1997;63(7-8):237-43. [MEDLINE: 9489309]

\section{Cheruku 2004 \{published data only\}}

Cheruku KK, Ghani A, Ahmad F, Pappas P, Silverman PR, Zelinger $\mathrm{A}$, et al. Efficacy of nonsteroidal anti-inflammatory medications for prevention of atrial fibrillation following coronary artery bypass graft surgery. Preventive Cardiology 2004;7(1):13-8. [MEDLINE: 15010623]

\section{Chow 2001 \{published data only\}}

Chow GK, Fabrizio MD, Steer T, Potter SR, Jarrett TW, Gelman S, et al. Prospective double-blind study of effect of ketorolac administration after laparoscopic urologic surgery. Journal of Endourology 2001;15(2):171-4. [MEDLINE: 21221791]

Daniels 2014 \{published data only\}

Daniels S, Solorio D, Young C. Lower-dose diclofenac capsules using SoluMatrix fine particle technology provide effective pain relief in a phase 3 study of patients with acute pain following bunionectomy [abstract]. Journal of Pain 2014;15(4 Suppl 1):S77. [EMBASE: 71404540]

Doyle 1998 \{published data only\}

Doyle E, Bowler GM. Pre-emptive effect of multimodal analgesia in thoracic surgery. British Journal of Anaesthesia 1998;80(2):147-51. [MEDLINE: 9602575]

\section{Fredman 1999 \{published data only\}}

Fredman B, Zohar E, Golan E, Tillinger M, Bernheim J, Jedeikin R. Diclofenac does not decrease renal blood flow or glomerular filtration in elderly patients undergoing orthopedic surgery. Anesthesia \& Analgesia 1999;88(1):149-54. [MEDLINE: 9895083]

Golan E, Fredman B, Tillinger M, Jedeikin R, Bernheim J. Diclofenac(d) does not decrease renal function in elderly patients undergoing surgery under general anasthesia

Effects of peri-operative nonsteroidal anti-inflammatory drugs on post-operative kidney function for adults with normal kidney function 
[abstract]. 35th Congress. European Renal Association. European Dialysis and Transplantation Association; 1998 Jun 6-9; Rimini, Italy. 1998:184. [CENTRAL: CN-00484115]

\section{Grimsby 2012 \{published data only\}}

Grimsby GM, Andrews PE, Castle EP, Nunez R, Mihalik LA, Chang $\mathrm{YH}$, et al. Long-term renal function after donor nephrectomy: secondary follow-up analysis of the randomized trial of ketorolac vs placebo. Urology 2014;84(1):78-81. [MEDLINE: 24976224]

Grimsby GM, Conley SP, Trentman TL, Castle EP, Andrews PE, Mihalik LA, et al. A double-blind randomized controlled trial of continuous intravenous Ketorolac vs placebo for adjuvant pain control after renal surgery. Mayo Clinic Proceedings 2012;87(11):1089-97. [MEDLINE: 23058854]

\section{Hynes 2006 \{published data only\}}

Hynes D, McCarroll M, Hiesse-Provost O. Analgesic efficacy of parenteral paracetamol (propacetamol) and diclofenac in post-operative orthopaedic pain. Acta Anaesthesiologica Scandinavica 2006;50(3):374-81. [MEDLINE: 16480474]

\section{Leeson 2007 \{published data only\}}

Leeson RM, Harrison S, Ernst CC, Hamilton DA, Mermelstein FH, Gawarecki DG, et al. Dyloject, a novel injectable diclofenac formulation, offers greater safety and efficacy than voltarol for postoperative dental pain. Regional Anesthesia \& Pain Medicine 2007;32(4):303-10. [MEDLINE: 17720114]

\section{Ma 2015 \{published data only\}}

Ma W, Wang K, Du J, Luan J, Lou G. Multi-dose parecoxib provides an immunoprotective effect by balancing $\mathrm{T}$ helper 1 (Th1), Th2, Th17 and regulatory T cytokines following laparoscopy in patients with cervical cancer. Molecular Medicine Reports 2015;11(4):2999-3008. [MEDLINE: 25434365]

\section{Merry 2002 \{published data only\}}

Merry AF, Sidebotham DA, Middleton NG, Calder MV, Webster CS. Tenoxicam $20 \mathrm{mg}$ or $\mathbf{4 0} \mathrm{mg}$ after thoracotomy: a prospective, randomized, double-blind, placebo-controlled study. Anaesthesia \& Intensive Care 2002;30(2):160-6. [MEDLINE: 12002922]

\section{Nussmeier 2005 \{published data only\}}

Nussmeier NA, Whelton AA, Brown MT, Langford RM, Hoeft A, Parlow JL, et al. Complications of the COX-2 inhibitors parecoxib and valdecoxib after cardiac surgery. New England Journal of Medicine 2005;352(11):1081-91. [MEDLINE: 15713945]

\section{Nussmeier 2006 \{published data only\}}

Nussmeier NA, Whelton AA, Brown MT, Joshi GP, Langford RM, Singla NK, et al. Safety and efficacy of the cyclooxygenase-2 inhibitors parecoxib and valdecoxib after noncardiac surgery. Anesthesiology 2006;104(3):518-26. [MEDLINE: 16508400]

\section{Nuutinen 1991 \{published data only\}}

Nuutinen L, Laitinen J. The effect of a nonsteroidal antiinflammatory drug, diclofenac, on renal function in patients undergoing total hip replacement operation [abstract]. Acta Anaesthesiologica Scandinavica 1991;35(Suppl 96):31.

\section{Parker 1994 \{published data only\}}

Parker RK, Holtmann B, Smith I, White PF. Use of ketorolac after lower abdominal surgery. Effect on analgesic requirement and surgical outcome. Anesthesiology 1994;80(1):6-12. [MEDLINE: 8291731]

\section{Rao 2000 \{published data only\}}

Rao AS, Cardosa M, Inbasegaran K. Morphine-sparing effect of ketoprofen after abdominal surgery. Anaesthesia \& Intensive Care 2000;28(1):22-6. [MEDLINE: 10701031]

\section{Ready 1994 \{published data only\}}

Ready LB, Brown CR, Stahlgren LH, Egan KJ, Ross B, Wild L, et al. Evaluation of intravenous ketorolac administered by bolus or infusion for treatment of postoperative pain. A doubleblind, placebo-controlled, multicenter study. Anesthesiology 1994;80(6):1277-86. [MEDLINE: 8010474]

\section{Southworth 2009 \{published data only\}}

Southworth S, Peters J, Rock A, Pavliv L. A multicenter, randomized, double-blind, placebo-controlled trial of intravenous ibuprofen 400 and $800 \mathrm{mg}$ every 6 hours in the management of postoperative pain. Clinical Therapeutics 2009;31(9):1922-35. [MEDLINE: 19843482]

\section{Varrassi 1999 \{published data only\}}

Varrassi G, Marinangeli F, Agro F, Aloe L, De Cillis P, De Nicola A, et al. A double-blinded evaluation of propacetamol versus ketorolac in combination with patient-controlled analgesia morphine: analgesic efficacy and tolerability after gynecologic surgery. Anesthesia \& Analgesia 1999;88(3):611-6. [MEDLINE: 10072016]

\section{Additional references}

\section{Bucaloiu 2012}

Bucaloiu ID, Kirchner HL, Norfolk ER, Hartle JE 2nd, Perkins RM. Increased risk of death and de novo chronic kidney disease following reversible acute kidney injury. Kidney International 2012;81(5):477-85. [MEDLINE: 22157656]

\section{Carmichael 2003}

Carmichael P, Carmichael AR. Acute renal failure in the surgical setting. ANZ Journal of Surgery 2003;73(3):144-53. [MEDLINE: 12608979]

\section{Chertow 2005}

Chertow GM, Burdick E, Honour M, Bonventre JV, Bates DW. Acute kidney injury, mortality, length of stay, and costs in hospitalized patients. Journal of the American Society of Nephrology 2005;16(11):3365-70. [MEDLINE: 16177006]

\section{Chou 2011}

Chou R, McDonagh MS, Nakamoto E, Griffin J. Analgesics for osteoarthritis: an update of the 2006 Comparative Effectiveness Review. Comparative Effectiveness Reviews, No. 38. Rockville (MD): Agency for Healthcare Research and Quality, 2011. [PUBMED: 22091473]

Effects of peri-operative nonsteroidal anti-inflammatory drugs on post-operative kidney function for adults with normal kidney function 


\section{Chou 2016}

Chou, R, Gordon, DB, de Leon-Casasola, OA, Rosenberg JM, Bickler S, Brennan T, et al. Management of Postoperative Pain: A Clinical Practice Guideline From the American Pain Society, the American Society of Regional Anesthesia and Pain Medicine, and the American Society of Anesthesiologists' Committee on Regional Anesthesia, Executive Committee, and Administrative Council.[Erratum appears in J Pain. 2016 Apr;17(4):508-10 Note: Dosage error in article text; PMID: 27036536]. Journal of Pain 2016;17(2):131-57. [MEDLINE: 26827847]

\section{Coca 2012}

Coca SG, Singanamala S, Parikh CR. Chronic kidney disease after acute kidney injury: a systematic review and metaanalysis. Kidney International 2012;81(5):442-8. [MEDLINE: 22113526]

\section{Derry 2009}

Derry CJ, Derry S, Moore RA, McQuay HJ. Single dose oral ibuprofen for acute postoperative pain in adults. Cochrane Database of Systematic Reviews 2009, Issue 3. [DOI: 10.1002/14651858.CD001548.pub2]

\section{Derry 2012a}

Derry S, Moore RA. Single dose oral aspirin for acute postoperative pain in adults. Cochrane Database of Systematic Reviews 2012, Issue 4. [DOI: 10.1002/14651858.CD002067.pub2]

\section{Derry 2012b}

Derry S, Moore RA. Single dose oral celecoxib for acute postoperative pain in adults. Cochrane Database of Systematic Reviews 2012, Issue 3. [DOI: 10.1002/14651858.CD004233.pub3]

\section{Follmann 1992}

Follmann D, Elliott P, Suh I, Cutler J. Variance imputation for overviews of clinical trials with continuous response. Journal of Clinical Epidemiology 1992;45(7):769-73. [MEDLINE: 1619456]

\section{Ftouh 2013}

Ftouh S, Thomas M, Acute Kidney Injury Guideline Development Group. Acute kidney injury: summary of NICE guidance. BMJ 2013;347:f4930. [MEDLINE: 23985310]

\section{GRADE 2008}

Guyatt GH, Oxman AD, Vist GE, Kunz R, Falck-Ytter Y, AlonsoCoello $P$, et al. GRADE: an emerging consensus on rating quality of evidence and strength of recommendations. $B M J$ 2008;336(7650):924-6. [MEDLINE: 18436948]

\section{Higgins 2003}

Higgins JP, Thompson SG, Deeks JJ, Altman DG. Measuring inconsistency in meta-analyses. BMJ 2003;327(7414):557-60. [MEDLINE: 12958120]

\section{Higgins 2011}

Higgins JP, Green S (editors). Cochrane Handbook for Systematic Reviews of Interventions Version 5.1.0 [updated March 2011]. The Cochrane Collaboration, 2011. Available from www.cochrane-handbook.org.

\section{KDIGO 2012}

KDIGO (Kidney Disease: Improving Global Outcomes) Acute Kidney Injury Work Group. KDIGO clinical practice guideline for acute kidney injury. Kidney International - Supplement 2012;2(1):1-138.

\section{Lassnigg 2004}

Lassnigg A, Schmidlin D, Mouhieddine M, Bachmann LM, Druml W, Bauer P, et al. Minimal changes of serum creatinine predict prognosis in patients after cardiothoracic surgery: a prospective cohort study. Journal of the American Society of Nephrology 2004;15(6):1597-605. [MEDLINE: 15153571]

\section{Lee 2007}

Lee A, Cooper MG, Craig JC, Knight JF, Keneally JP. Effects of nonsteroidal anti-inflammatory drugs on postoperative renal function in adults with normal renal function. Cochrane Database of Systematic Reviews 2007, Issue 2. [DOI: 10.1002/14651858.CD002765.pub3]

\section{McDaid 2010}

McDaid C, Maund E, Rice S, Wright K, Jenkins B, Woolacott N. Paracetamol and selective and non-selective non-steroidal anti-inflammatory drugs (NSAIDs) for the reduction of morphine-related side effects after major surgery: a systematic review. Health Technology Assessment (Winchester, England) 2010;14(17):1-153, iii-iv. [MEDLINE: 20346263]

\section{MHRA 2009}

Medicines and Healthcare Products Regulatory Agency. Drug Safety Update: Volume 2 Issue 10, May 2009. http:// webarchive.nationalarchives.gov.uk/20141206024920/ http://www.mhra.gov.uk/Publications/Safetyguidance/ DrugSafetyUpdate/CON046451 Vol. (accessed 19 April 2018).

\section{NICE 2017}

NICE National Institute for Health and Care Excellence. British National Formulary, Aspirin. https://www.evidence.nhs.uk/ formulary/bnf/current/4-central-nervous-system/47analgesics/471-non-opioid-analgesics-and-compoundanalgesic-preparations/aspirin 2017.

\section{O'Rourke 2002}

O'Rourke K. Mixed means and medians: a unified approach to deal with disparate outcome summaries. Symposium on systematic reviews: pushing the boundaries. Oxford, 2002; Vol. 49.

\section{Schünemann 2011a}

Schünemann HJ, Oxman AD, Higgins JP, Vist GE, Glasziou P, Guyatt GH. Chapter 11: Presenting results and 'Summary of findings' tables. In: Higgins JP, Green S (editors). Cochrane Handbook for Systematic Reviews of Interventions Version 5.1.0 [updated March 2011]. The Cochrane Collaboration, 2011. Available from www.cochrane-handbook.org.

\section{Schünemann 2011b}

Schünemann HJ, Oxman AD, Higgins JP, Deeks JJ, Glasziou P, Guyatt GH. Chapter 12: Interpreting results and drawing conclusions. In: Higgins JP, Green S (editors). Cochrane Handbook for Systematic Reviews of Interventions Version

Effects of peri-operative nonsteroidal anti-inflammatory drugs on post-operative kidney function for adults with normal kidney function 
5.1.0 [updated March 2011]. The Cochrane Collaboration, 2011. Available from www.cochrane-handbook.org.

\section{Whelton 1999}

Whelton A. Nephrotoxicity of nonsteroidal anti-inflammatory drugs: physiologic foundations and clinical implications. American Journal of Medicine 1999;106(5B):13S-24S. [MEDLINE: 10390124]

\section{CHARACTERISTICS OF STUDIES}

Characteristics of included studies [ordered by study ID]

\section{References to other published versions of this review Bell 2014a}

Bell S, Marwick CA, Rennie T, Davey P. Effects of peri-operative nonsteroidal anti-inflammatory drugs on postoperative kidney function for adults with normal kidney function. Cochrane Database of Systematic Reviews 2014, Issue 8. [DOI: 10.1002/14651858.CD011274]

Aitken 1992

\begin{tabular}{ll}
\hline Methods & Study design: RCT \\
& - Study duration: not reported \\
\hline Participants & - Country: UK follow-up: $48 \mathrm{~h}$ \\
- Setting: single centre \\
- Inclusion criteria: undergoing elective upper abdominal surgery \\
- Number: treatment group 1 (19); treatment group 2 (23); control group (21) \\
- Mean age (years): treatment group 1 (47.2); treatment group 2 (48.6); control group (56.1) \\
- Sex (M/F): treatment group 1 (19/10); treatment group 2 (10/13); control group (10/11) \\
- Exclusion criteria: respiratory insufficiency hepatic or kidney impairment; abuse of alcohol or drugs
\end{tabular}

Interventions

Treatment group 1

- Ketorolac: $12.5 \mathrm{mg} / \mathrm{h} \mathrm{IM}$ infusion for $30 \mathrm{~min}$ during surgery then $2.5 \mathrm{mg} / \mathrm{h}$ for $47.5 \mathrm{~h}$, with normal saline injections every $4 \mathrm{~h}$

Treatment group 2

- Ketorolac: $10 \mathrm{mg}$ every $4 \mathrm{~h}$ IM for $48 \mathrm{~h}$, first dose during surgery

Control group

- Intermittent and continuous infusions of saline to match other groups

\begin{tabular}{ll}
\hline Outcomes & Pre-operative and post-operative $\mathrm{CrCl}$, urine output, sodium output, potassium output \\
\hline Notes & - Funding Source: Syntex research gave financial assistance and supplied the study drugs
\end{tabular}

\section{Risk of bias}

\begin{tabular}{lll}
\hline Bias & Authors' judgement & Support for judgement \\
\hline $\begin{array}{l}\text { Random sequence genera- } \\
\text { tion (selection bias) }\end{array}$ & Unclear risk & $\begin{array}{l}\text { Study was described as randomised, method of randomisation was not report- } \\
\text { ed }\end{array}$ \\
\hline $\begin{array}{l}\text { Allocation concealment } \\
\text { (selection bias) }\end{array}$ & Unclear risk & Insufficient information to permit judgement \\
\hline $\begin{array}{l}\text { Blinding of participants } \\
\text { and personnel (perfor- } \\
\text { mance bias) }\end{array}$ & Unclear risk & $\begin{array}{l}\text { Study described as "double-blind"; insufficient information to permit judge- } \\
\text { All outcomes }\end{array}$ \\
\hline
\end{tabular}

Effects of peri-operative nonsteroidal anti-inflammatory drugs on post-operative kidney function for adults with normal kidney function 20 (Review)

Copyright $\odot 2018$ The Cochrane Collaboration. Published by John Wiley \& Sons, Ltd. 
Aitken 1992 (Continued)

Blinding of outcome as- Unclear risk Insufficient information to permit judgement sessment (detection bias)

All outcomes

Incomplete outcome data High risk (attrition bias)

All outcomes
67 patients were randomised, of which 63 patients were included in the patient data table.

Six patients were withdrawn from the study after 24 or $48 \mathrm{~h}$ of treatment due to equipment failure or on patient's request. No data on randomisation of the withdrawn patients.

Of remaining 61 patients there is missing data from 15 patients, probably equally distributed amongst the intervention and placebo groups.

Selective reporting (re- Low risk Study protocol matches outcomes presented
porting bias)

Other bias High risk A commercial funding source was used for this study

Brinkmann 1998

\begin{tabular}{ll}
\hline Methods & Study design: parallel RCT \\
& - Study duration: not reported \\
& - Study follow-up: $24 \mathrm{~h}$ \\
\hline Participants & - Country: Germany \\
- Setting: single centre \\
- Inclusion criteria: elective infrarenal aortic surgery \\
- Number: treatment group (67); control group (64) \\
- Mean age \pm SD (years): treatment group (13 \pm 2$)$; control group $(13 \pm 3)$ \\
- Sex (M/F): treatment group $(11 / 2)$; control group (11/2) \\
- Exclusion criteria: NSAID medication at least 7 days prior to surgery; history of significant renal dis- \\
\end{tabular}

\begin{tabular}{ll}
\hline Interventions & Treatment group \\
- Ibuprofen: $400 \mathrm{mg}$ IV before skin incision \\
Control group \\
- Placebo: aliquot IV before skin incision \\
\hline Outcomes \\
$\begin{array}{ll}\text { C } \\
\text { and } 24 \mathrm{~h} \text { after cross-clamping (on the 1st postoperative day). }\end{array}$ \\
\hline Notes & Funding Source: not reported \\
& $2 / 13$ ), indication for administration unclear.
\end{tabular}

\section{Risk of bias}

\section{Bias \\ Authors' judgement Support for judgement}

Random sequence genera- Unclear risk tion (selection bias)
Study was described as randomised, method of randomisation was not reported

Effects of peri-operative nonsteroidal anti-inflammatory drugs on post-operative kidney function for adults with normal kidney function 
Brinkmann 1998 (Continued)

\begin{tabular}{l}
$\begin{array}{l}\text { Allocation concealment } \\
\text { (selection bias) }\end{array}$ \\
\hline
\end{tabular}

Blinding of participants Unclear risk Insufficient information to permit judgement

and personnel (perfor-

mance bias)

All outcomes

Blinding of outcome as-
sessment (detection bias) $\quad$ Unclear risk Insufficient information to permit judgement

sessment (detection bias)

All outcomes

\begin{tabular}{lll}
\hline $\begin{array}{l}\text { Incomplete outcome data } \\
\text { (attrition bias) } \\
\text { All outcomes }\end{array}$ & Unclear risk & Insufficient information to permit judgement \\
\hline $\begin{array}{l}\text { Selective reporting (re- } \\
\text { porting bias) }\end{array}$ & Low risk & $\begin{array}{l}\text { All intended measurements were reported at baseline, } 1 \text { and } 6 \text { hours after } \\
\text { cross-clamping, and on the first POD }\end{array}$ \\
\hline Other bias & Unclear risk & $\begin{array}{l}\text { The study was conducted by the anaesthetics department of the University of } \\
\text { Ulm. There is no mention of funding sources }\end{array}$ \\
\hline
\end{tabular}

Eljezi 2017

\begin{tabular}{|c|c|}
\hline Methods & $\begin{array}{l}\text { - Study design: parallel RCT } \\
\text { - Study duration: not reported } \\
\text { - Study follow-up: } 48 \mathrm{~h}\end{array}$ \\
\hline Participants & $\begin{array}{l}\text { - Country: France } \\
\text { - Setting: inpatient } \\
\text { - Inclusion criteria: patients undergoing elective open heart surgery or coronary artery bypass grafting } \\
\text { - Number: treatment group } 1 \text { ( } 25) \text {; treatment group } 2(25) \text {; treatment group } 3(24) \text { control group }(23) \\
\text { - Mean age } \pm \mathrm{SD} \text { (years): treatment group } 1(63 \pm 9) \text {; treatment group } 2 \text { (63. } \pm 7) \text {; treatment group } 3 \text { (60 } \\
\pm 11) \text {; control group ( } 58 \pm 13) \\
\text { - Sex (M/F): treatment group } 1(23 / 2) \text {; treatment group } 2(22 / 3) \text {; treatment group } 3(24 / 0) \text { control group } \\
(12 / 11) \\
\text { - Exclusion criteria: kidney insufficiency defined as a } \mathrm{CrCl}<60 \mathrm{~mL} / \mathrm{min}^{-1} \text {; hepatic insufficiency; conges- } \\
\text { tive heart failure with ejection fraction < } 45 \% \text {; history of gastric peptic ulcer or GI bleeding; DM needing } \\
\text { insulin therapy; preoperative coagulation disorder; allergy to NSAID; pregnancy or breastfeeding }\end{array}$ \\
\hline
\end{tabular}

$\begin{array}{ll}\text { Interventions } & \text { Treatment group } 1 \\ \text { - IV ketoprofen: } 0.5 \mathrm{mg} / \mathrm{kg} \text { every } 6 \mathrm{~h} \text { for } 48 \mathrm{~h} \\ \text { Treatment group } 2 \\ \text { - IV ketoprofen } 0.25 \mathrm{mg} / \mathrm{kg} \text { every } 6 \mathrm{~h} \text { for } 48 \mathrm{~h} \\ \text { Treatment group } 3 \\ \text { - IV ketoprofen: } 0.125 \mathrm{mg} / \mathrm{kg} \text { every } 6 \mathrm{~h} \text { for } 48 \mathrm{~h} \\ \text { Control group } \\ \text { - IV normal saline }\end{array}$


Eljezi 2017 (Continued)

- Urine output every $4 \mathrm{~h}$ until $48 \mathrm{~h}$ post-operatively

$\begin{array}{ll}\text { Notes } & \text { Only } 48 \mathrm{~h} \mathrm{SCr} \text { and urine output results documented } \\ & \text { - } 100 \text { patients randomised, } 97 \text { patient analysed }\end{array}$

\section{Risk of bias}

\begin{tabular}{|c|c|c|}
\hline Bias & Authors' judgement & Support for judgement \\
\hline $\begin{array}{l}\text { Random sequence genera- } \\
\text { tion (selection bias) }\end{array}$ & Unclear risk & $\begin{array}{l}\text { Study was described as randomised, method of randomisation was not report- } \\
\text { ed }\end{array}$ \\
\hline $\begin{array}{l}\text { Allocation concealment } \\
\text { (selection bias) }\end{array}$ & Low risk & Allocation was concealed in an envelope \\
\hline $\begin{array}{l}\text { Blinding of participants } \\
\text { and personnel (perfor- } \\
\text { mance bias) } \\
\text { All outcomes }\end{array}$ & Low risk & $\begin{array}{l}\text { The study drug was prepared by an anaesthetist nurse not involved of post-op- } \\
\text { erative care, under the control of the anaesthetist in charge of the patient, who } \\
\text { opened the allocation envelope }\end{array}$ \\
\hline $\begin{array}{l}\text { Blinding of outcome as- } \\
\text { sessment (detection bias) } \\
\text { All outcomes }\end{array}$ & Unclear risk & Insufficient information to permit judgement \\
\hline $\begin{array}{l}\text { Incomplete outcome data } \\
\text { (attrition bias) } \\
\text { All outcomes }\end{array}$ & Low risk & There is no incomplete data \\
\hline $\begin{array}{l}\text { Selective reporting (re- } \\
\text { porting bias) }\end{array}$ & High risk & $\begin{array}{l}\text { Methods state } 4 \text { hourly urinary output measurements until } 48 \mathrm{~h} \text { post-opera- } \\
\text { tively and SCr measurement for POD } 1 \text { and POD } 2 \text {. No urinary output results } \\
\text { documented for } 0-44 \mathrm{~h} \text {. SCr documented at baseline and a percentage rise at } \\
48 \mathrm{~h} \text { reported. No results for POD } 1 \text { reported }\end{array}$ \\
\hline Other bias & Low risk & $\begin{array}{l}\text { The study was conducted by the Department of Anesthesiology (Medecine } \\
\text { Peri-Operatoire) and the Clinical Pharmacology centre (CPC-CIC) of the Uni- } \\
\text { versity Hospital of Clermont-Ferrand (CHU Clermont-Ferrand), France. The } \\
\text { sponsorship was limited to supplies and expenses. The sponsorship included } \\
\text { payment for employees for study design, patient's inclusion, data entry, and } \\
\text { analysis of the data. They also provided the study drugs at no cost. They had } \\
\text { no influence or interference after the protocol was designed }\end{array}$ \\
\hline
\end{tabular}

Fayaz 2004

\begin{tabular}{ll}
\hline Methods & Study design: parallel RCT \\
& - Study duration: not reported \\
& - Study follow-up: $24 \mathrm{~h}$ \\
\hline Participants & Country: UK \\
- Setting: single centre \\
- Inclusion criteria: patients undergoing coronary artery bypass graft surgery \\
- Number: treatment group 1 (17); treatment group 2 (17); control group (20) \\
- Mean age \pm SD (years): treatment group 1 (59.4 \pm 8.4$) ;$ treatment group 2 (64.0 \pm 8.4$) ;$ control group \\
\\
- $64.3 \pm 7.9)$
\end{tabular}

Effects of peri-operative nonsteroidal anti-inflammatory drugs on post-operative kidney function for adults with normal kidney function 
Fayaz 2004 (Continued)

- Exclusion criteria: previous history of peptic ulcer disease or GI bleeding; hepatic and/or kidney insufficiency ( $\mathrm{SCr}>120 \mu \mathrm{mol} / \mathrm{L})$; insulin-dependent DM; left ventricular ejection fraction 30\%; weight > 110 $\mathrm{kg}$ or $<55 \mathrm{~kg}$; known allergy to study drugs.

- Post-operative exclusion criteria: patients with prolonged cardiopulmonary bypass (180 min), patients requiring intra-aortic balloon pump support, patients who had excessive post-operative bleeding $150 \mathrm{~mL} / \mathrm{h}$ for the first $2 \mathrm{~h}$, and patients with early post-operative SCr increase ( $20 \%$ of baseline)

\begin{tabular}{ll}
\hline Interventions & Treatment group 1 \\
- Diclofenac: $100 \mathrm{mg}$ \\
- Paracetamol: $1 \mathrm{~g}$ \\
- Suppositories were administered $2 \mathrm{~h}$ after surgery. Diclofenac was repeated after $18 \mathrm{~h}$ and paraceta- \\
$\quad$ mol every $6 \mathrm{~h}$ for $24 \mathrm{~h}$ \\
Treatment group 2 \\
- Diclofenac: $100 \mathrm{mg}, 2$ and $18 \mathrm{~h}$ after surgery \\
Control Group \\
- Placebo suppositories: 2 at same time as treatment group 1 \\
\hline Outcomes & Scr \\
\hline Notes & Funding source: not reported \\
\hline
\end{tabular}

Risk of bias

\begin{tabular}{|c|c|c|}
\hline Bias & Authors' judgement & Support for judgement \\
\hline $\begin{array}{l}\text { Random sequence genera- } \\
\text { tion (selection bias) }\end{array}$ & Low risk & "The randomization code was computer generated by Lab View version 2" \\
\hline $\begin{array}{l}\text { Allocation concealment } \\
\text { (selection bias) }\end{array}$ & Low risk & Insufficient information to permit judgement \\
\hline $\begin{array}{l}\text { Blinding of participants } \\
\text { and personnel (perfor- } \\
\text { mance bias) } \\
\text { All outcomes }\end{array}$ & Low risk & Drugs made up by pharmacist \\
\hline $\begin{array}{l}\text { Blinding of outcome as- } \\
\text { sessment (detection bias) } \\
\text { All outcomes }\end{array}$ & Unclear risk & Insufficient information to permit judgement \\
\hline $\begin{array}{l}\text { Incomplete outcome data } \\
\text { (attrition bias) } \\
\text { All outcomes }\end{array}$ & High risk & $\begin{array}{l}6 / 60 \text { patients withdrawn. Equally distributed across study groups and similar } \\
\text { reasons for withdrawal given. } 2 \text { patients were withdrawn before entering the } \\
\text { study due to oliguria and an early post-operative SCr rise ( }>20 \% \text { from base- } \\
\text { line) }\end{array}$ \\
\hline $\begin{array}{l}\text { Selective reporting (re- } \\
\text { porting bias) }\end{array}$ & Low risk & Study protocol matches outcomes presented \\
\hline Other bias & Unclear risk & Insufficient information to permit judgement \\
\hline
\end{tabular}

Effects of peri-operative nonsteroidal anti-inflammatory drugs on post-operative kidney function for adults with normal kidney function 
Hynninen 2000

\begin{tabular}{|c|c|}
\hline Methods & $\begin{array}{l}\text { - Study design: parallel RCT } \\
\text { - Study duration: not reported } \\
\text { - Study follow-up: } 24 \mathrm{~h}\end{array}$ \\
\hline Participants & $\begin{array}{l}\text { - Country: Canada } \\
\text { - Setting: inpatient } \\
\text { - Inclusion criteria: patients undergoing coronary artery bypass graft surgery were randomised. } \\
\text { - Number: treatment group } 1(28) \text {; treatment group } 2(28) \text {; treatment group } 3(27) \text {; control group ( } 31) \\
\text { - Mean age } \pm \mathrm{SD} \text { (years): treatment group } 1(59 \pm 9) \text {; treatment group } 2(60 \pm 7) \text {; treatment group } 3 \text { (58 } \\
\pm 9) \text {; control group }(55 \pm 9) \\
\text { - Sex (M/F): treatment group } 1(20 / 8) \text {; treatment group } 2(24 / 4) \text {; treatment group } 3(21 / 6) \text {; control group } \\
\text { ( } 28 / 3) \\
\text { - Exclusion criteria: ejection fraction < } 20 \% \text {; previous cardiac surgery; insulin-dependent DM; weight } \\
>100 \mathrm{~kg} \text { or < } 60 \mathrm{~kg} \text {; kidney insufficiency }(\mathrm{SCr}>130 \mu \mathrm{mol} / \mathrm{L}) \text {; allergy to propofol, morphine or NSAID; } \\
\text { active peptic ulcer disease; history of GI bleeding; age > } 75 \text { years; warfarin, dipyridamole or heparin } \\
\text { therapy preoperatively }\end{array}$ \\
\hline
\end{tabular}

\begin{tabular}{ll}
\hline Interventions & Treatment group 1 \\
- & Diclofenac: $75 \mathrm{mg}$ suppository twice/d after surgery \\
Treatment group 2 \\
- Ketoprofen: $100 \mathrm{mg}$ suppository twice/d after surgery \\
Treatment group 3 \\
- Indomethacin: $100 \mathrm{mg}$ suppository twice/d after surgery \\
Control group \\
- Placebo suppository twice/d after surgery \\
\hline Outcomes \\
\hline Notes
\end{tabular}

Risk of bias

\begin{tabular}{|c|c|c|}
\hline Bias & Authors' judgement & Support for judgement \\
\hline $\begin{array}{l}\text { Random sequence genera- } \\
\text { tion (selection bias) }\end{array}$ & Unclear risk & $\begin{array}{l}\text { Study was described as randomised, method of randomisation was not report- } \\
\text { ed }\end{array}$ \\
\hline $\begin{array}{l}\text { Allocation concealment } \\
\text { (selection bias) }\end{array}$ & Low risk & $\begin{array}{l}\text { Randomisation and preparation of study drug in identically shaped supposito- } \\
\text { ries was done by hospital pharmacy }\end{array}$ \\
\hline $\begin{array}{l}\text { Blinding of participants } \\
\text { and personnel (perfor- } \\
\text { mance bias) } \\
\text { All outcomes }\end{array}$ & Low risk & $\begin{array}{l}\text { Randomisation and preparation of study drug in identically shaped supposito- } \\
\text { ries was done by hospital pharmacy }\end{array}$ \\
\hline $\begin{array}{l}\text { Blinding of outcome as- } \\
\text { sessment (detection bias) } \\
\text { All outcomes }\end{array}$ & Unclear risk & Insufficient information to permit judgement \\
\hline $\begin{array}{l}\text { Incomplete outcome data } \\
\text { (attrition bias) } \\
\text { All outcomes }\end{array}$ & Low risk & $\begin{array}{l}6 / 114 \text { patients withdrawn. Of these six patients, } 1 \text { patient was withdrawn af- } \\
\text { ter one dose of indomethacin because of SCr increase }>20 \% \text { post-operatively. } \\
\text { This patient did not receive further NSAIDs as per protocol and was not includ- }\end{array}$ \\
\hline
\end{tabular}

Effects of peri-operative nonsteroidal anti-inflammatory drugs on post-operative kidney function for adults with normal kidney function 25 (Review)

Copyright (c) 2018 The Cochrane Collaboration. Published by John Wiley \& Sons, Ltd. 
Hynninen 2000 (Continued)

ed in the post-operative outcome table. This event was mentioned in the discussion of the paper. The plausible effect size of this one event is probably not enough to have a clinically relevant impact on observed effect size

\begin{tabular}{lll}
\hline $\begin{array}{l}\text { Selective reporting (re- } \\
\text { porting bias) }\end{array}$ & Low risk & Study protocol matches outcomes presented \\
\hline Other bias & Unclear risk & Insufficient information to permit judgement \\
\hline
\end{tabular}

Immer 2003

\begin{tabular}{|c|c|}
\hline Methods & $\begin{array}{l}\text { - Study design: parallel RCT } \\
\text { - Study duration: June } 2000 \text { to October } 2000 \\
\text { - Study follow-up: until hospital discharge }\end{array}$ \\
\hline Participants & $\begin{array}{l}\text { - Country: Switzerland } \\
\text { - Setting: single centre } \\
\text { - Inclusion criteria: patients undergoing coronary artery bypass operation } \\
\text { - Number: treatment group } 1(20) \text {; treatment group } 2(20) \text {; control group }(20) \\
\text { - Mean age } \pm \text { SD (years): treatment group } 1(56.6 \pm 8.8) \text {; treatment group } 2(60.5 \pm 6.1) \text {; control group } \\
(60.5 \pm 8.5) \\
\text { - Sex (M/F): treatment group } 1(3 / 17) \text {; treatment group } 2(3 / 17) \text {; control group }(5 / 15) \\
\text { - Exclusion criteria: > } 70 \text { years; left ventricular ejection fraction < 30\%; previous history of peptic ulcer } \\
\text { disease or Gl bleeding; hepatic or kidney insufficiency; known allergy to tramadol or NSAIDs and pre- } \\
\text { operative analgesic treatment } \\
\text { - Post-operative period exclusion criteria: delayed transfer to the general ward; SCr more than } 150 \\
\mu m o l / L \text {, and altered mental status }\end{array}$ \\
\hline
\end{tabular}

\begin{tabular}{ll}
\hline Interventions & Treatment group 1 \\
- & Diclofenac: $50 \mathrm{mg}$ every $8 \mathrm{~h}$ orally on POD 2 and 3 \\
& Treatment group 2 \\
- Etodolac: $300 \mathrm{mg}$ every $8 \mathrm{~h}$ orally on POD 2 and 3 \\
Control group \\
- Tramadol: slow-release (150 mg every 12 h orally) \\
\hline - Pre-operative and post-operative SCr \\
\hline Notes \\
- Tramadol group (weak opioid) not included in analysis 1 SCr data not included as study drugs were not given \\
- CrCl measured on POD 4 \\
- Funding Source: Study drugs were supplied by Grunenthal, Novartis Pharma and Sigma-Tau, Switzer-
\end{tabular}

\section{Risk of bias}

\begin{tabular}{lll}
\hline Bias & Authors' judgement & Support for judgement \\
\hline $\begin{array}{l}\text { Random sequence genera- } \\
\text { tion (selection bias) }\end{array}$ & Unclear risk & $\begin{array}{l}\text { Study was described as randomised, method of randomisation was not report- } \\
\text { ed }\end{array}$ \\
\hline
\end{tabular}

Effects of peri-operative nonsteroidal anti-inflammatory drugs on post-operative kidney function for adults with normal kidney function 26 
Immer 2003 (Continued)

\begin{tabular}{lll}
$\begin{array}{l}\text { Allocation concealment } \\
\text { (selection bias) }\end{array}$ & Unclear risk & Insufficient information to permit judgement \\
\hline $\begin{array}{l}\text { Blinding of participants } \\
\text { and personnel (perfor- }\end{array}$ & Unclear risk & Insufficient information to permit judgement \\
mance bias) & & \\
All outcomes & &
\end{tabular}

\begin{tabular}{lll}
\hline $\begin{array}{l}\text { Blinding of outcome as- } \\
\text { sessment (detection bias) } \\
\text { All outcomes }\end{array}$ & Unclear risk & Insufficient information to permit judgement \\
\hline $\begin{array}{l}\text { Incomplete outcome data } \\
\begin{array}{l}\text { (attrition bias) } \\
\text { All outcomes }\end{array}\end{array}$ & High risk & $\begin{array}{l}\text { 9 out of } 69 \text { patients were excluded post-operatively, prior to randomisation. } \\
\text { One of these patients was withdrawn due to a post-operative } \mathrm{SCr} \text { rise }(>150 \\
\mu \mathrm{mol} / \mathrm{L})\end{array}$ \\
\hline $\begin{array}{l}\text { Selective reporting (re- } \\
\text { porting bias) }\end{array}$ & Low risk & Study protocol matches outcomes presented \\
\hline Other bias & High risk & A commercial funding source was used for this study \\
\hline
\end{tabular}

Irwin 1995

\begin{tabular}{|c|c|}
\hline Methods & $\begin{array}{l}\text { - Study design: parallel RCT } \\
\text { - Study duration: not reported } \\
\text { - Study follow-up: } 48 \mathrm{~h} \text { post-operatively }\end{array}$ \\
\hline Participants & $\begin{array}{l}\text { - Country: Hong Kong } \\
\text { - Setting: single centre } \\
\text { - Inclusion criteria: males undergoing elective minor orthopaedic surgery } \\
\text { - Number: treatment group }(11) \text {; control group }(10) \\
\text { - Mean age } \pm S D \text { (years): treatment group }(45.6 \pm 19.0) \text {; control group }(33.5 \pm 9.5) \\
\text { - Sex (M/F): not reported } \\
\text { - Exclusion criteria: patients with respiratory, cardiac, hepatic or kidney insufficiency; history of peptic } \\
\text { ulcer disease or allergy to aspirin, diclofenac or other prostaglandin inhibiting compounds }\end{array}$ \\
\hline Interventions & $\begin{array}{l}\text { Treatment group } \\
\text { - Diclofenac: } 100 \mathrm{mg} \text { suppository before surgery then } 100 \mathrm{mg} \text { at } 8 \mathrm{am} \text { on day } 1 \\
\text { Control group } \\
\text { - Placebo: suppository before surgery and at 8am on day } 1\end{array}$ \\
\hline Outcomes & $\begin{array}{l}\text { - Pre-operative and post-operative (at } 24 \mathrm{~h} \text { and } 48 \mathrm{~h} \text { ) measurements of } \mathrm{CrCl} \text {, urine output, sodium out- } \\
\text { put, potassium output, fractional excretion of sodium, fractional excretion of potassium }\end{array}$ \\
\hline Notes & - Funding source: not reported \\
\hline
\end{tabular}

\section{Risk of bias}

\begin{tabular}{lll}
\hline Bias & Authors' judgement & Support for judgement \\
\hline $\begin{array}{ll}\text { Random sequence genera- } \\
\text { tion (selection bias) }\end{array}$ & Unclear risk & $\begin{array}{l}\text { Study was described as randomised, method of randomisation was not report- } \\
\text { ed }\end{array}$ \\
\hline
\end{tabular}

Effects of peri-operative nonsteroidal anti-inflammatory drugs on post-operative kidney function for adults with normal kidney function 
Irwin 1995 (Continued)

Allocation concealment Unclear risk Insufficient information to permit judgement
(selection bias)

Blinding of participants Unclear risk Insufficient information to permit judgement
and personnel (performance bias)

All outcomes

$\begin{array}{ll}\text { Blinding of outcome as- } & \text { Unclear risk }\end{array}$ Insufficient information to permit judgement

All outcomes

\begin{tabular}{lll}
\hline $\begin{array}{l}\text { Incomplete outcome data } \\
\text { (attrition bias) } \\
\text { All outcomes }\end{array}$ & Low risk & $\begin{array}{l}\text { One patient withdrew from study; reason for missing outcome data unlikely to } \\
\text { be related to outcome }\end{array}$ \\
\hline $\begin{array}{l}\text { Selective reporting (re- } \\
\text { porting bias) }\end{array}$ & Low risk & Study protocol matches outcomes presented \\
\hline Other bias & Unclear risk & Insufficient information to permit judgement \\
\hline
\end{tabular}

\section{Jones 2000}

\begin{tabular}{ll}
\hline Methods & Study design: parallel RCT \\
- Study duration: not reported \\
- Study follow-up: $96 \mathrm{~h}$ post-operatively \\
\hline Participants & Country: Australia \\
- Setting: single centre \\
- Inclusion criteria: women aged 50 to 70 years undergoing major gynaecological surgery (ovarian, uter- \\
- ine or cervical cancer) \\
- Number: treatment group (15); control group (15) \\
- Sex age \pm SD (years): treatment group (60.3 \pm 6.3$) ;$ control group (60.3 \pm 6.9$)$ \\
- Exclusion criteria: kidney or hepatic impairment; bleeding diathesis; hypersensitivity to NSAIDs; asth- \\
ma; medications known to interfere with tenoxicam disposition
\end{tabular}

\begin{tabular}{ll}
\hline Interventions & Treatment group \\
& - Tenoxicam: $20 \mathrm{mg}$ IV given $2 \mathrm{~h}$ before surgery \\
& Control group \\
& - Normal saline: IV given $2 \mathrm{~h}$ before surgery \\
\hline Outcomes & Pre-operative and post-operative (at $2,24,48,72$, and $96 \mathrm{~h})$ measurements of $\mathrm{CrCl}, \mathrm{SCr}$, fractional \\
& excretion of sodium and potassium \\
\hline Notes & Funding source: unknown quantity of support provided by Hoffmann-La Roche \& Co, Basle, Switzer- \\
& land
\end{tabular}

\section{Risk of bias}




\section{Jones 2000 (Continued)}

Random sequence genera- Low risk Roche pharmaceuticals coded and allocated 30 patients using random numtion (selection bias) ber tables

\begin{tabular}{l}
$\begin{array}{l}\text { Allocation concealment } \\
\text { (selection bias) }\end{array} \quad$ Low risk Study drugs made up by Roche pharmaceuticals \\
\hline
\end{tabular}

The allocation was not released until the end of clinical data collection

Blinding of participants $\quad$ Low risk The allocation was not released until the end of clinical data collection
and personnel (perfor-

mance bias)

All outcomes

Blinding of outcome as- $\quad$ Low risk The allocation was not released until the end of clinical data collection
sessment (detection bias)
All outcomes

All outcomes

Incomplete outcome data Low risk No incomplete data
(attrition bias)

All outcomes

\begin{tabular}{lll}
\hline $\begin{array}{l}\text { Selective reporting (re- } \\
\text { porting bias) }\end{array}$ & Low risk & Study protocol matches outcomes presented \\
\hline Other bias & High risk & A commercial funding source was used for this study \\
\hline
\end{tabular}

\section{Khalil 2006a}

\begin{tabular}{ll}
\hline Methods & Study design: RCT \\
& - Study duration: 2 years \\
& Study follow-up: 48 hours \\
\hline Participants & Country: UK \\
- Setting: single centre \\
- Inclusion criteria: elective coronary artery bypass grafting \\
- Mean age \pm SD (years): treatment group (56.7 \pm 9.1$) ;$ control group $(58.8 \pm 6.6)$ \\
- Sex (M/F): not reported \\
- Exclusion criteria: diabetics; on anticoagulants; previous cerebrovascular disease
\end{tabular}

\begin{tabular}{ll} 
Interventions & Treatment group \\
& - Parecoxib: single IV dose of $40 \mathrm{mg}$ given at closure of sternotomy \\
& Control group \\
& Placebo: single IV dose given at closure of sternotomy \\
\hline Outcomes & - 24 hour urinary $\mathrm{CrCl}$, urinary a-1-microglobulin \\
\hline Notes & - Funding: Pharmacia \\
& tients)
\end{tabular}

\section{Risk of bias}

Effects of peri-operative nonsteroidal anti-inflammatory drugs on post-operative kidney function for adults with normal kidney function 29 (Review)

Copyright @ 2018 The Cochrane Collaboration. Published by John Wiley \& Sons, Ltd. 
Khalil 2006a (Continued)

\begin{tabular}{|c|c|c|}
\hline Bias & Authors' judgement & Support for judgement \\
\hline $\begin{array}{l}\text { Random sequence genera- } \\
\text { tion (selection bias) }\end{array}$ & Low risk & Computerised randomisation using a number generator \\
\hline $\begin{array}{l}\text { Allocation concealment } \\
\text { (selection bias) }\end{array}$ & Low risk & A third party placed the results of the randomisation in sealed envelopes \\
\hline $\begin{array}{l}\text { Blinding of participants } \\
\text { and personnel (perfor- } \\
\text { mance bias) } \\
\text { All outcomes }\end{array}$ & Low risk & $\begin{array}{l}\text { Envelopes were opened at close of the surgery and a third party prepared the } \\
\text { study medication (placebo or treatment) which looked identical }\end{array}$ \\
\hline $\begin{array}{l}\text { Blinding of outcome as- } \\
\text { sessment (detection bias) } \\
\text { All outcomes }\end{array}$ & Unclear risk & Insufficient information to permit judgement \\
\hline $\begin{array}{l}\text { Incomplete outcome data } \\
\text { (attrition bias) } \\
\text { All outcomes }\end{array}$ & Low risk & $\begin{array}{l}\text { Initial power calculations resulted in an intended study population size of } 60 \\
\text { patients. Following a global announcement of Pfizer that parecoxib was 'con- } \\
\text { traindicated in patients with ischaemic heart disease' further inclusion in the } \\
\text { study was terminated at } 40 \text {. Data of all } 40 \text { patients is presented }\end{array}$ \\
\hline $\begin{array}{l}\text { Selective reporting (re- } \\
\text { porting bias) }\end{array}$ & Low risk & Study protocol matches outcomes presented \\
\hline Other bias & High risk & $\begin{array}{l}\text { Commercial funding source Pharmacia, which is the manufacturer of Parecox- } \\
\text { ib }\end{array}$ \\
\hline
\end{tabular}

\section{Koppert 2006}

\begin{tabular}{ll}
\hline Methods & Study design: parallel RCT \\
- Study duration: 2002 to 2003 \\
- Study follow-up: 3 POD \\
\hline Participants & Country: Germany \\
- Setting: single centre \\
- Inclusion criteria: elderly patients $\geq 85$ years undergoing hip replacement or surgery of the femoral \\
shaft \\
- \\
- \\
Mumber: treatment group 1 (25); treatment group 2 (25); control group (25) \\
( $76.7 \pm 8.6)$ \\
- Sex (M/F): treatment group 1 (9/16); treatment group 2 (14/11); control group (11/14) \\
nary arterial bypass, stroke or transient ischaemic attack; uncontrolled hypertension or uncontrolled \\
DM; kidney disease; bleeding disorders; any disease that the investigator believed would pose a risk \\
to the patient
\end{tabular}

Interventions

Treatment group 1

- Parecoxib: $40 \mathrm{mg}$ and 12 hourly subsequently

Treatment group 2

- IV paracetamol: infusion of $1000 \mathrm{mg}$ and 6 hourly subsequently

Control group

Effects of peri-operative nonsteroidal anti-inflammatory drugs on post-operative kidney function for adults with normal kidney function 30 (Review)

Copyright $\odot 2018$ The Cochrane Collaboration. Published by John Wiley \& Sons, Ltd. 
Koppert 2006 (Continued)

- IV saline: over $10 \mathrm{~min}$

\begin{tabular}{ll}
\hline Outcomes & Differences in $\mathrm{CrCl}$ pre-operatively and up to $6 \mathrm{~h}$ post-operatively \\
\hline Notes & - Funding source: unknown quantity of support provided by Bristol-Myers Squibb
\end{tabular}

\section{Risk of bias}

\begin{tabular}{|c|c|c|}
\hline Bias & Authors' judgement & Support for judgement \\
\hline $\begin{array}{l}\text { Random sequence genera- } \\
\text { tion (selection bias) }\end{array}$ & Unclear risk & $\begin{array}{l}\text { Study was described as randomised, method of randomisation was not report- } \\
\text { ed }\end{array}$ \\
\hline $\begin{array}{l}\text { Allocation concealment } \\
\text { (selection bias) }\end{array}$ & Low risk & $\begin{array}{l}\text { All study medication solutions were prepared by a hospital pharmacist who } \\
\text { was not involved in the data collection }\end{array}$ \\
\hline $\begin{array}{l}\text { Blinding of participants } \\
\text { and personnel (perfor- } \\
\text { mance bias) } \\
\text { All outcomes }\end{array}$ & Low risk & $\begin{array}{l}\text { The anaesthesiologist, nursing staff, and the investigators were all blinded to } \\
\text { the treatment. At the surgical ward, patients and nursing staff were unblinded } \\
\text { to the medication. }\end{array}$ \\
\hline $\begin{array}{l}\text { Blinding of outcome as- } \\
\text { sessment (detection bias) } \\
\text { All outcomes }\end{array}$ & Unclear risk & Insufficient information to permit judgement \\
\hline $\begin{array}{l}\text { Incomplete outcome data } \\
\text { (attrition bias) } \\
\text { All outcomes }\end{array}$ & Low risk & $\begin{array}{l}\text { Eight of } 83 \text { patients withdrew from study. Reasons for missing outcome data } \\
\text { unlikely to be related to true outcome }\end{array}$ \\
\hline $\begin{array}{l}\text { Selective reporting (re- } \\
\text { porting bias) }\end{array}$ & Low risk & Study protocol matches outcomes presented \\
\hline Other bias & High risk & A commercial funding source was used for this study \\
\hline
\end{tabular}

Kostamovaara 1996

\begin{tabular}{|c|c|}
\hline Methods & $\begin{array}{l}\text { - Study design: parallel RCT } \\
\text { - Study duration: not reported } \\
\text { - Study follow-up: } 2 \text { POD }\end{array}$ \\
\hline Participants & $\begin{array}{l}\text { - Country: Finland } \\
\text { - Setting: single centre } \\
\text { - Inclusion criteria: patients undergoing total hip (62) or knee (14) replacement } \\
\text { - Number: treatment group } 1(19) \text {; treatment group } 2(20) \text {; treatment group } 3 \text { (18) control group (19) } \\
\text { - Mean age } \pm \text { SD (years): treatment group } 1(61 \pm 10) \text {; treatment group } 2 \text { (58 } \pm 8) \text {; treatment group } 3 \text { (64 } \\
\pm 5) \text { control group }(61 \pm 7) \\
\text { - Sex (M/F): treatment group } 1(5 / 14) \text {; treatment group } 2(10 / 10) \text {; Treatment group } 3 \text { (15/3); control } \\
\text { group (6/13) } \\
\text { - Exclusion criteria: hepatic, kidney or cardiac failure; bleeding or coagulation disorders; peptic ulcer; } \\
\text { asthma; hypersensitivity to aspirin or other NSAIDs; on cytostatic treatment }\end{array}$ \\
\hline
\end{tabular}

Interventions

Treatment group 1

- Ketoprofen: $50 \mathrm{mg}$ IV loading dose for $30 \mathrm{~min}$, followed $50 \mathrm{mg}$ infusion over following $11.5 \mathrm{~h}$ 
Kostamovaara 1996 (Continued)

\section{Treatment group 2}

- Ketoprofen: $100 \mathrm{mg}$ IV loading dose for $30 \mathrm{~min}$, followed $100 \mathrm{mg}$ infusion over following $11.5 \mathrm{~h}$

Treatment group 3

- Ketoprofen: $150 \mathrm{mg}$ IV loading dose for $30 \mathrm{~min}$, followed $150 \mathrm{mg}$ infusion over following $11.5 \mathrm{~h}$

Control group

- Isotonic saline: IV infusion for $30 \mathrm{~min}$, followed by saline over following $11.5 \mathrm{~h}$

\begin{tabular}{ll}
\hline Outcomes & Pre-operative and day $2 \mathrm{SCr}$ \\
\hline Notes & - Funding source: Grant awarded by the Professor Arno Hollmen Fund, Finland
\end{tabular}

\section{Risk of bias}

\begin{tabular}{|c|c|c|}
\hline Bias & Authors' judgement & Support for judgement \\
\hline $\begin{array}{l}\text { Random sequence genera- } \\
\text { tion (selection bias) }\end{array}$ & Unclear risk & $\begin{array}{l}\text { Study was described as randomised, method of randomisation was not report- } \\
\text { ed }\end{array}$ \\
\hline $\begin{array}{l}\text { Allocation concealment } \\
\text { (selection bias) }\end{array}$ & Unclear risk & Insufficient information to permit judgement \\
\hline $\begin{array}{l}\text { Blinding of participants } \\
\text { and personnel (perfor- } \\
\text { mance bias) } \\
\text { All outcomes }\end{array}$ & Unclear risk & Insufficient information to permit judgement \\
\hline $\begin{array}{l}\text { Blinding of outcome as- } \\
\text { sessment (detection bias) } \\
\text { All outcomes }\end{array}$ & Unclear risk & Insufficient information to permit judgement \\
\hline $\begin{array}{l}\text { Incomplete outcome data } \\
\text { (attrition bias) } \\
\text { All outcomes }\end{array}$ & Low risk & $\begin{array}{l}\text { Three of } 76 \text { patients withdrawn from study; reasons for missing outcome data } \\
\text { unlikely to be related to true outcome }\end{array}$ \\
\hline $\begin{array}{l}\text { Selective reporting (re- } \\
\text { porting bias) }\end{array}$ & Low risk & Study protocol matches outcomes presented \\
\hline Other bias & Low risk & Non-profit organisation funding received \\
\hline
\end{tabular}

Kulik 2004

\begin{tabular}{ll}
\hline Methods & - Study design: parallel RCT \\
& - Study duration: not reported \\
& - Study follow-up: 4 POD \\
\hline Participants & Country: Canada \\
- Setting: single centre \\
- Inclusion criteria: patients undergoing elective coronary artery bypass graft \\
- Mean age \pm SE (years): treatment group $(58.9 \pm 1.5) ;$ control group $(60.8 \pm 1.4)$ \\
- Sex (M/F): treatment group (46/4); control group (45/3)
\end{tabular}

Effects of peri-operative nonsteroidal anti-inflammatory drugs on post-operative kidney function for adults with normal kidney function 
Kulik 2004 (Continued)

- Exclusion criteria: left ventricle ejection fraction < 20\%; $\mathrm{SCr}>130 \mu \mathrm{mol} / \mathrm{L}$; preoperative use of $\mathrm{H} 2$ antagonists, proton pump inhibitors, steroids, NSAIDs (with exception of aspirin), narcotics or illicit drugs; history of peptic ulcer, liver disease or NSAID allergy

\section{Risk of bias}

\begin{tabular}{|c|c|c|}
\hline Bias & Authors' judgement & Support for judgement \\
\hline $\begin{array}{l}\text { Random sequence genera- } \\
\text { tion (selection bias) }\end{array}$ & Low risk & Computerised randomisation \\
\hline $\begin{array}{l}\text { Allocation concealment } \\
\text { (selection bias) }\end{array}$ & Low risk & Medication was prepared by hospital pharmacy and appeared identical \\
\hline $\begin{array}{l}\text { Blinding of participants } \\
\text { and personnel (perfor- } \\
\text { mance bias) } \\
\text { All outcomes }\end{array}$ & Low risk & $\begin{array}{l}\text { Medication administration and data collection were done in a double blinded } \\
\text { fashion }\end{array}$ \\
\hline $\begin{array}{l}\text { Blinding of outcome as- } \\
\text { sessment (detection bias) } \\
\text { All outcomes }\end{array}$ & Low risk & $\begin{array}{l}\text { Medication administration and data collection were done in a double blinded } \\
\text { fashion }\end{array}$ \\
\hline $\begin{array}{l}\text { Incomplete outcome data } \\
\text { (attrition bias) } \\
\text { All outcomes }\end{array}$ & High risk & $\begin{array}{l}16 \text { of } 98 \text { patients withdrawn from the study, of these one patient had a base- } \\
\text { line creatinine of } 115 \mu \mathrm{mol} / \mathrm{L} \text { pre-operatively. Remainder of the reasons for } \\
\text { missing outcome data unlikely to be related to true outcome } \\
\text { Despite } 16 \text { patients did not receive the intervention as allocated on randomi- } \\
\text { sation - post-operative results of all } 98 \text { patients presented. The plausible effect } \\
\text { size among missing outcomes enough to induce clinically relevant bias in ob- } \\
\text { served effect size }\end{array}$ \\
\hline $\begin{array}{l}\text { Selective reporting (re- } \\
\text { porting bias) }\end{array}$ & Low risk & Study protocol matches outcomes presented \\
\hline Other bias & Low risk & The study appears to be free of other sources of bias \\
\hline
\end{tabular}

Laisalmi 2001a

Methods - Study design: parallel RCT

Effects of peri-operative nonsteroidal anti-inflammatory drugs on post-operative kidney function for adults with normal kidney function 
Laisalmi 2001a (Continued)

- Study duration: not reported

- Study follow-up: 2 POD

- Country: Finland
- Setting: single centre
- Inclusion criteria: ASA physical status I-II women scheduled to undergo elective breast surgery
- Number: treatment group (15); control group (15)
- Mean age \pm SD (years): treatment group $(49 \pm 7)$; control group $(45 \pm 9)$
- Sex (M/F): all female
- Exclusion criteria: patients with abnormal kidney or hepatic function

Interventions

Treatment group

- $30 \mathrm{mg}$ ketorolac: $30 \mathrm{mg}$ IM with the premedication, "at the end of," and $6 \mathrm{~h}$ after anaesthesia

Control group

- Saline: 3 IM injections

Outcomes

- Kidney function was assessed using sensitive markers that monitor the function of different entities of the kidney at after $2 \mathrm{~h}$ of anaesthesia, 2 and $12 \mathrm{~h}$ after the end of anaesthesia, as well as on the first and on the second POD: U-NAG/creat for proximal tubular function, PuO2 is a marker of medullary homeostasis, and EPO that of the tubulointerstitium

- The traditional function markers such as SCr and urea were also measured at $12 \mathrm{~h}$ after the end of anaesthesia, and on the first and second POD

- Urine output

Notes - Funding Source: Helsinki University Central Hospital EVO Grant

\section{Risk of bias}

\begin{tabular}{|c|c|c|}
\hline Bias & Authors' judgement & Support for judgement \\
\hline $\begin{array}{l}\text { Random sequence genera- } \\
\text { tion (selection bias) }\end{array}$ & Unclear risk & $\begin{array}{l}\text { Study was described as randomised, method of randomisation was not report- } \\
\text { ed }\end{array}$ \\
\hline $\begin{array}{l}\text { Allocation concealment } \\
\text { (selection bias) }\end{array}$ & Unclear risk & Insufficient information to permit judgement \\
\hline $\begin{array}{l}\text { Blinding of participants } \\
\text { and personnel (perfor- } \\
\text { mance bias) } \\
\text { All outcomes }\end{array}$ & Unclear risk & Insufficient information to permit judgement \\
\hline $\begin{array}{l}\text { Blinding of outcome as- } \\
\text { sessment (detection bias) } \\
\text { All outcomes }\end{array}$ & Unclear risk & Insufficient information to permit judgement \\
\hline $\begin{array}{l}\text { Incomplete outcome data } \\
\text { (attrition bias) } \\
\text { All outcomes }\end{array}$ & Low risk & No missing data \\
\hline $\begin{array}{l}\text { Selective reporting (re- } \\
\text { porting bias) }\end{array}$ & Low risk & Study protocol matches outcomes presented \\
\hline Other bias & Low risk & Non-profit organisation funding received \\
\hline
\end{tabular}

Effects of peri-operative nonsteroidal anti-inflammatory drugs on post-operative kidney function for adults with normal kidney function 34 (Review)

Copyright $\odot 2018$ The Cochrane Collaboration. Published by John Wiley \& Sons, Ltd. 
McCrory 2002

\begin{tabular}{|c|c|}
\hline Methods & $\begin{array}{l}\text { - Study design: parallel RCT } \\
\text { - Study duration: not reported } \\
\text { - Study follow-up: until } 72 \mathrm{~h} \text { post follow-up from ICU }\end{array}$ \\
\hline Participants & $\begin{array}{l}\text { - Country: Ireland } \\
\text { - Setting: single centre } \\
\text { - Inclusion criteria: elective thoracic surgery via thoracotomy } \\
\text { - Number } \\
\text { * Spinal: treatment group } 1(10) \text {; treatment group } 2(10) \text {; control group }(10) \\
\text { * Epidural: treatment group } 1(5) \text {; treatment group } 2(5) \text {; control group }(5) \\
\text { - Mean age } \pm \text { SD (years) } \\
\text { * Spinal: treatment group } 1(64 \pm 4) \text {, treatment group } 2(63 \pm 2) \text {, control }(62 \pm 2) \\
\text { * Epidural: treatment group } 1(58 \pm 6) \text {, treatment group } 2(56 \pm 8) \text {, control }(66 \pm 3) \\
\text { - Sex (M/F) } \\
\text { * Spinal: treatment group } 1(6 / 4) \text {; treatment group } 2(5 / 5) \text {; control group }(6 / 4) \\
\text { * Epidural: treatment group } 1(3 / 2) \text {; treatment group } 2(3 / 2) \text {; control group (3/2) } \\
\text { - Exclusion criteria: history of peptic ulcer disease; renal and hepatic dysfunction; psychiatric illness; } \\
\text { any chronic pain syndrome; and consumption of NSAIDs, corticosteroids, or any other drug known to } \\
\text { interfere with prostaglandin production for } 14 \text { days before surgery. }\end{array}$ \\
\hline
\end{tabular}

Interventions

Two types of administration - spinal and epidural. Each were assigned to following 3 groups

Treatment group 1

- Nimesulide: 100 mg twice daily

Treatment group 2

- Ibuprofen: 400 mg 4 times daily

Control group

- No NSAIDs or placebo

\begin{tabular}{ll}
\hline Outcomes & 24 h urinary creatinine \\
\hline Notes & . Funding Source: Baggott Street Hospital Academic Research Grant \\
\hline
\end{tabular}

\section{Risk of bias}

\begin{tabular}{lll}
\hline Bias & Authors' judgement & Support for judgement \\
\hline $\begin{array}{l}\text { Random sequence genera- } \\
\text { tion (selection bias) }\end{array}$ & Unclear risk & $\begin{array}{l}\text { Study was described as randomised, method of randomisation was not report- } \\
\text { ed. }\end{array}$ \\
\hline $\begin{array}{l}\text { Allocation concealment } \\
\text { (selection bias) }\end{array}$ & Unclear risk & Insufficient information to permit judgement \\
\hline $\begin{array}{l}\text { Blinding of participants } \\
\text { and personnel (perfor- } \\
\text { mance bias) }\end{array}$ & High risk & Open-label study \\
All outcomes & & \\
\hline
\end{tabular}

\begin{tabular}{|c|c|c|}
\hline $\begin{array}{l}\text { Blinding of outcome as- } \\
\text { sessment (detection bias) } \\
\text { All outcomes }\end{array}$ & Low risk & $\begin{array}{l}\text { Anaesthetists and patients did have knowledge of the study and allocated } \\
\text { treatment group. This knowledge is unlikely to influence the primary renal } \\
\text { outcome; } 24 \text { hour urinary creatinine }\end{array}$ \\
\hline
\end{tabular}

Effects of peri-operative nonsteroidal anti-inflammatory drugs on post-operative kidney function for adults with normal kidney function 
McCrory 2002 (Continued)

Nursing staff was unaware of patients participating in the study and will therefore not impact on the pain score outcomes presented

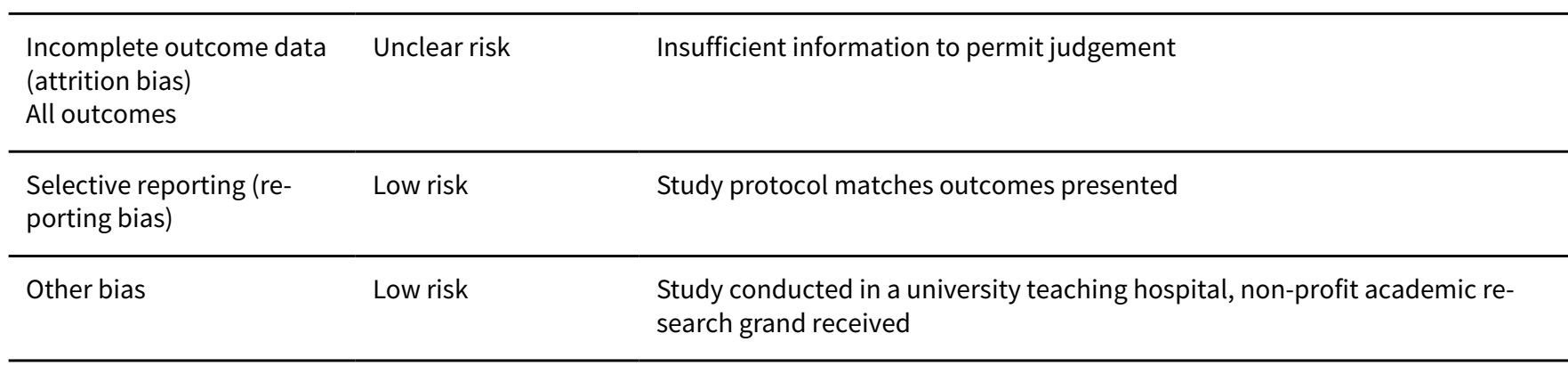

\section{NAFARM 2011}

\begin{tabular}{ll}
\hline Methods & Study design: parallel RCT \\
- Study duration: 2005 to 2009 \\
- Study follow-up: until hospital discharge \\
\hline Participants & Country: Brazil \\
- Setting: single centre \\
- Inclusion criteria: patients undergoing coronary artery bypass graft surgery \\
- Number: treatment group (82); control group (79) \\
- Mean age \pm SD (years): treatment group $(59.7 \pm 9.8)$; control group $(58.0 \pm 8.6)$ \\
- Sex (M/F): treatment group $(50 / 32) ;$ control group $(52 / 27)$ \\
- Exclusion criteria: allergies to study medication; pregnant; off-pump surgery; history of GI bleeding; \\
chronic liver disease; kidney insufficiency (SCr $>132.6$ mol/L); thrombocytopenia; reported preoper- \\
ative use of glucocorticoids; previous diagnosis of atrial fibrillation
\end{tabular}

- Naproxen: $275 \mathrm{mg}$ twice/d for 5 days from the moment the patients returned to the ICU post surgery

Control group

- Placebo: twice/d for 5 days from the moment the patients returned to the ICU post surgery

\begin{tabular}{|c|c|c|}
\hline Outcomes & \multicolumn{2}{|c|}{$\begin{array}{l}\text { - Kidney failure (SCr elevation } \geq 50 \% \text { from baseline) } \\
\text { - Death } \\
\text { - Length of hospital stay }\end{array}$} \\
\hline Notes & \multicolumn{2}{|c|}{ - Funding source: no funding received } \\
\hline \multicolumn{3}{|l|}{ Risk of bias } \\
\hline Bias & Authors' judgement & Support for judgement \\
\hline $\begin{array}{l}\text { Random sequence genera- } \\
\text { tion (selection bias) }\end{array}$ & Low risk & $\begin{array}{l}\text { "The pharmacist made the randomization list and allocated the placebo and } \\
\text { naproxen pills without the knowledge of any other person" }\end{array}$ \\
\hline $\begin{array}{l}\text { Allocation concealment } \\
\text { (selection bias) }\end{array}$ & Low risk & $\begin{array}{l}\text { Sealed envelope, medication appears identical, nursing staff giving out drugs } \\
\text { are not part of the investigation team }\end{array}$ \\
\hline
\end{tabular}


NAFARM 2011 (Continued)

Blinding of participants Low risk Sealed envelope, medication appears identical, nursing staff giving out drugs and personnel (perforare not part of the investigation team

mance bias)

All outcomes

\begin{tabular}{|c|c|c|}
\hline $\begin{array}{l}\text { Blinding of outcome as- } \\
\text { sessment (detection bias) } \\
\text { All outcomes }\end{array}$ & Low risk & $\begin{array}{l}\text { Sealed envelope, medication appears identical, nursing staff giving out drugs } \\
\text { are not part of the investigation team }\end{array}$ \\
\hline $\begin{array}{l}\text { Incomplete outcome data } \\
\text { (attrition bias) } \\
\text { All outcomes }\end{array}$ & Low risk & $\begin{array}{l}\text { Results of all } 161 \text { randomised patients reported for primary and secondary } \\
\text { outcomes }\end{array}$ \\
\hline $\begin{array}{l}\text { Selective reporting (re- } \\
\text { porting bias) }\end{array}$ & Low risk & Study protocol matches outcomes presented \\
\hline Other bias & Low risk & The study appears to be free of other sources of bias \\
\hline
\end{tabular}

Ott 2003

\begin{tabular}{|c|c|}
\hline Methods & $\begin{array}{l}\text { - Study design: parallel RCT } \\
\text { - Study duration: January and May } 2000 \\
\text { - Study follow-up:14 POD }\end{array}$ \\
\hline Participants & $\begin{array}{l}\text { - Countries: USA, Canada, Germany, UK } \\
\text { - Setting: multicentre (58) } \\
\text { - Inclusion criteria: patients undergoing coronary artery bypass graft surgery. } \\
\text { - Number: treatment group ( } 311) \text {; control group }(151) \\
\text { - Mean age } \pm \text { SD (years): treatment group }(60.3 \pm 8.2) \text {; control group }(61.3 \pm 8.0) \\
\text { - Sex (M/F): treatment group (265/46); control group (135/16) } \\
\text { - Exclusion criteria: patients undergoing emergency surgery and those with a recent (48 h) Ml; in- } \\
\text { sulin-dependent or uncontrolled diabetes; increased concentrations of liver enzymes SCr }>1.5 \mathrm{mg} / \mathrm{dL} \\
\text { (or } 133 \mu \text { mol/L); any coagulopathy; stroke or transient ischaemic attack within } 6 \text { months; substance } \\
\text { abuse (opioids, any other analgesics, or alcohol); allergy to NSAIDs; history of gastric or duodenal ul- } \\
\text { cer; intra-operative complications }\end{array}$ \\
\hline
\end{tabular}

\begin{tabular}{|c|c|}
\hline \multirow[t]{2}{*}{ Interventions } & $\begin{array}{l}\text { Treatment group } \\
\text { - Parecoxib: } 40 \mathrm{mg} \text { IV was administered within } 30 \mathrm{~min} \text { after extubation and every } 12 \mathrm{~h} \text { for a minimum } \\
\text { of } 3 \text { days. Subsequently, oral valdecoxib at a dose of } 40 \mathrm{mg} \text { every } 12 \mathrm{~h} \text { was initiated and administered } \\
\text { for a combined total of } 14 \text { days }\end{array}$ \\
\hline & $\begin{array}{l}\text { Control group } \\
\text { - IV placebo: administered within } 30 \text { min after extubation and every } 12 \mathrm{~h} \text { for a minimum of } 3 \text { days. Sub- } \\
\text { sequently, oral placebo every } 12 \mathrm{~h} \text { was initiated and administered for a combined total of } 14 \text { days }\end{array}$ \\
\hline Outcomes & $\begin{array}{l}\text { - } \mathrm{SCr} \\
\text { - Clinical adverse outcomes }\end{array}$ \\
\hline Notes & $\begin{array}{l}\text { - A typing error was found in the presentation of results on page } 1485 \text { (an increase in creatinine of } 0.7 \\
\mathrm{mg} / \mathrm{dL} \text { is equivalent to } 62 \mu \mathrm{mol} / \mathrm{L} \text {, instead of } 0.62 \mu \mathrm{mol} / \mathrm{L} \text { as quoted in the text). } \\
\text { - Note: creatinine rise as cause for withdrawal was } 1.9 \% \text { vs } 1.3 \% \text { in treatment vs placebo group } \\
\text { - Funding source: not reported }\end{array}$ \\
\hline
\end{tabular}

Effects of peri-operative nonsteroidal anti-inflammatory drugs on post-operative kidney function for adults with normal kidney function 
Ott 2003 (Continued)

\section{Risk of bias}

\begin{tabular}{|c|c|c|}
\hline Bias & Authors' judgement & Support for judgement \\
\hline $\begin{array}{l}\text { Random sequence genera- } \\
\text { tion (selection bias) }\end{array}$ & Unclear risk & $\begin{array}{l}\text { Study was described as randomised, method of randomisation was not report- } \\
\text { ed }\end{array}$ \\
\hline $\begin{array}{l}\text { Allocation concealment } \\
\text { (selection bias) }\end{array}$ & Unclear risk & Insufficient information to permit judgement \\
\hline $\begin{array}{l}\text { Blinding of participants } \\
\text { and personnel (perfor- } \\
\text { mance bias) } \\
\text { All outcomes }\end{array}$ & Unclear risk & Insufficient information to permit judgement \\
\hline
\end{tabular}

\begin{tabular}{|c|c|c|}
\hline $\begin{array}{l}\text { Blinding of outcome as- } \\
\text { sessment (detection bias) } \\
\text { All outcomes }\end{array}$ & Unclear risk & Insufficient information to permit judgement \\
\hline $\begin{array}{l}\text { Incomplete outcome data } \\
\text { (attrition bias) } \\
\text { All outcomes }\end{array}$ & High risk & $\begin{array}{l}\text { After randomisation and the administration of at least one dose of the study } \\
\text { drug, } 26 \% \text { of the } 462 \text { patients (equally distributed between groups) were with- } \\
\text { drawn from the study. Most frequent reason for withdrawal was an adverse } \\
\text { event (15.6\%) of which } 1.3 \% \text { in the control group and } 1.9 \% \text { in the NSAID group } \\
\text { were due to rise in creatinine. Plausible effect size among missing outcomes } \\
\text { enough to induce clinically relevant bias in observed effect size }\end{array}$ \\
\hline
\end{tabular}

Selective reporting (re- Low risk Study protocol matches outcomes presented
porting bias)

Other bias Unclear risk Insufficient information to permit judgement

\section{Perttunen 1992}

\begin{tabular}{ll}
\hline Methods & Study design: parallel RCT \\
- Study duration: not reported \\
- Study follow-up:72 h post-operatively \\
\hline Participants & Country: Finland \\
- Setting: single centre \\
- Inclusion criteria: patients undergoing thoracoscopy \\
- Number: treatment group (15); control group (15) \\
- Mean age, range (years): treatment group (59.1, 38 to 75$)$; control group $(55.3,23$ to 74$)$ \\
- Sex (M/F): treatment group 1 (11/4); control group (13/2) \\
ation; haemorrhagic diathesis and asthma; allergy to aspirin, NSAIDs or morphine; confusion; preop- \\
erative FEV1 < $60 \%$ of reference value; sleep apnoea
\end{tabular}

Interventions

Treatment group

- Diclofenac: $400 \mathrm{mg}$ in $400 \mathrm{~mL} \mathrm{NaCl}$ 0.9\%; $25 \mathrm{~mL}$ bolus given immediately after surgery then $2 \mathrm{mg} / \mathrm{kg} / 24$ $\mathrm{h}$ for $48 \mathrm{~h}$

Control group

- $0.9 \% \mathrm{NaCl}: 400 \mathrm{~mL} ; 25 \mathrm{~mL}$ bolus given immediately after surgery then $2 \mathrm{~mL} / \mathrm{kg} / 24 \mathrm{~h}$ for $48 \mathrm{~h}$

Effects of peri-operative nonsteroidal anti-inflammatory drugs on post-operative kidney function for adults with normal kidney function 38 (Review)

Copyright @ 2018 The Cochrane Collaboration. Published by John Wiley \& Sons, Ltd. 
Perttunen 1992 (Continued)

\begin{tabular}{lll} 
Outcomes & - Pre-operative and post-operative SCr and urine output \\
\hline Notes & • Funding support: supported by the Paulo Foundation, Finland \\
\hline Risk of bias & Authors' judgement & Support for judgement \\
\hline Bias & Unclear risk & $\begin{array}{l}\text { Study was described as randomised, method of randomisation was not report- } \\
\text { ed }\end{array}$ \\
\hline $\begin{array}{l}\text { Random sequence genera- } \\
\text { tion (selection bias) }\end{array}$ & Insufficient information to permit judgement \\
\hline $\begin{array}{l}\text { Allocation concealment } \\
\text { (selection bias) }\end{array}$ & Unclear risk & Study medication looks identical; double blind study \\
\hline $\begin{array}{l}\text { Blinding of participants } \\
\text { and personnel (perfor- } \\
\text { mance bias) } \\
\text { All outcomes }\end{array}$ & Low risk & \\
\hline
\end{tabular}

Blinding of outcome as-
sessment (detection bias) $\quad$ Low risk $\quad$ Nurse who made up the infusions was not involved in the study

All outcomes

\begin{tabular}{ll}
\hline $\begin{array}{l}\text { Incomplete outcome data } \\
\text { (attrition bias) }\end{array}$ & Unclear risk \\
All outcomes & $\begin{array}{l}\text { Missing secondary outcome data from 4/30 patients; insufficient reporting of } \\
\text { reason behind missing data to permit judgement. }\end{array}$
\end{tabular}

All outcomes

Selective reporting (re- Low risk Study protocol matches outcomes presented
porting bias)
porting bias)

\begin{tabular}{ll}
\hline Other bias $\quad$ Low risk $\quad$ Non-profit organisation funding received \\
\hline
\end{tabular}

\section{Perttunen 1999}

\begin{tabular}{|c|c|}
\hline Methods & $\begin{array}{l}\text { - Study design: parallel RCT } \\
\text { - Study duration: not reported } \\
\text { - Study follow-up: } 2 \text { POD }\end{array}$ \\
\hline Participants & $\begin{array}{l}\text { - Country: Finland } \\
\text { - Setting: single centre } \\
\text { - } 30 \text { patients undergoing thoracoscopy } \\
\text { - Number: treatment group } 1(10) \text {; treatment group } 2 \text { (10); control group (10) } \\
\text { - Mean age, range (years): treatment group } 1 \text { ( } 50.3,26 \text { to } 70) \text {; treatment group } 2 \text { ( } 40.6,18 \text { to } 64) \text {; control } \\
\text { group ( } 45.0,25 \text { to } 70) \\
\text { - Sex (M/F): treatment group } 1(5 / 5) \text {; treatment group } 2 \text { (6/4); control group (5/5) } \\
\text { - Exclusion criteria: > } 75 \text { years; cardiac, kidney or hepatic failure; history of GI bleeding or peptic ulcer- } \\
\text { ation; haemorrhagic diathesis and asthma; allergy to aspirin, NSAIDs or morphine; confusion, preop- } \\
\text { erative FEV1 < } 60 \% \text { of reference value; sleep apnoea }\end{array}$ \\
\hline Interventions & $\begin{array}{l}\text { Treatment group } 1 \\
\text { - Diclofenac: bolus of } 17 \mathrm{mg} 1 \mathrm{~h} \text { before anaesthesia; followed by a } 48 \mathrm{~h} \text { continuous infusion at } 1 \mathrm{mg} / \\
\mathrm{kg} / 24 \mathrm{~h} \\
\text { Treatment group } 2\end{array}$ \\
\hline
\end{tabular}

Effects of peri-operative nonsteroidal anti-inflammatory drugs on post-operative kidney function for adults with normal kidney function 39 (Review)

Copyright @ 2018 The Cochrane Collaboration. Published by John Wiley \& Sons, Ltd. 
Perttunen 1999 (Continued)

- Diclofenac: bolus of $10 \mathrm{mg} 1 \mathrm{~h}$ before anaesthesia, followed by a $48 \mathrm{~h}$ continuous infusion at $1.2 \mathrm{mg} /$ $\mathrm{kg} / 24 \mathrm{~h}$

Control group

- Equivalent placebo bolus and continuous infusion

\begin{tabular}{ll}
\hline Outcomes & Creatinine at baseline, $1 \mathrm{~h}$, first POD and second POD \\
& - Urine output measurement 0-22 h and 22-46 h \\
\hline Notes & - Funding Source: Helsinki University Central Hospital Research Fund and Helsinki University \\
\hline
\end{tabular}

\section{Risk of bias}

\begin{tabular}{|c|c|c|}
\hline Bias & Authors' judgement & Support for judgement \\
\hline $\begin{array}{l}\text { Random sequence genera- } \\
\text { tion (selection bias) }\end{array}$ & Low risk & $\begin{array}{l}\text { Study was described as randomised, method of randomisation was not report- } \\
\text { ed }\end{array}$ \\
\hline $\begin{array}{l}\text { Allocation concealment } \\
\text { (selection bias) }\end{array}$ & Low risk & Envelopes were sealed and opened by nurse who was not involved in the study \\
\hline $\begin{array}{l}\text { Blinding of participants } \\
\text { and personnel (perfor- } \\
\text { mance bias) } \\
\text { All outcomes }\end{array}$ & Low risk & $\begin{array}{l}\text { Envelopes were sealed and opened by recovery nurse who made up the infu- } \\
\text { sions. This nurse was not involved in the study }\end{array}$ \\
\hline $\begin{array}{l}\text { Blinding of outcome as- } \\
\text { sessment (detection bias) } \\
\text { All outcomes }\end{array}$ & Low risk & Assessors were blinded to allocation of infusions \\
\hline $\begin{array}{l}\text { Incomplete outcome data } \\
\text { (attrition bias) } \\
\text { All outcomes }\end{array}$ & Low risk & No missing data \\
\hline $\begin{array}{l}\text { Selective reporting (re- } \\
\text { porting bias) }\end{array}$ & Low risk & Study protocol matches outcomes presented \\
\hline Other bias & Low risk & Non-profit organisation funding received \\
\hline
\end{tabular}

\section{POISE-2 2013}

\begin{tabular}{|c|c|}
\hline Methods & $\begin{array}{l}\text { - Study design: parallel RCT } \\
\text { - Study duration: January } 2011 \text { to December } 2013 \\
\text { - Study follow-up: } 30 \text { POD }\end{array}$ \\
\hline Participants & $\begin{array}{l}\text { - Countries: Canada, USA, Colombia, India, Spain, Australia, South Africa, Denmark, Hong Kong, Bel- } \\
\text { gium, Austria, Pakistan, Peru, Malaysia, Italy, Chile, Switzerland, France, UK, Brazil, New Zealand } \\
\text { - Setting: multicentre (88) } \\
\text { - Inclusion criteria: patients undergoing non-cardiac surgery } \\
\text { - Number: treatment group } 1 \text { (3443); treatment group } 2 \text { (3453); control group } 1(3462) \text {; control group } \\
2 \text { (3452) } \\
\text { - Mean age } \pm \text { SD (years): treatment group } 1(69.3 \pm 9.9) \text {; treatment group } 2(69.1 \pm 10.0) \text {; control group } \\
1(69.1 \pm 10.0) \text {; control group } 2(69.2 \pm 9.9) \\
\text { - Sex (M/F): treatment group } 1(1808 / 1635) \text {;treatment group } 2(1846 / 1607) \text {; control group } 1(1861 / 1601) \text {; } \\
\text { control group } 2(1823 / 1629)\end{array}$ \\
\hline
\end{tabular}

Effects of peri-operative nonsteroidal anti-inflammatory drugs on post-operative kidney function for adults with normal kidney function 40 (Review)

Copyright (c) 2018 The Cochrane Collaboration. Published by John Wiley \& Sons, Ltd. 
POISE-2 2013 (Continued)

- Exclusion criteria: ESKD prior to randomisation; no pre- or post-randomisation SCr measurement available
Treatment group 1

- Aspirin: $200 \mathrm{mg} 2$ to $4 \mathrm{~h}$ before surgery and then $100 \mathrm{mg}$ for either 7 days (for those taking long-term aspirin) or 30 days (for those not taking long-term aspirin)

Treatment group 2 (not included in meta-analyses)

- Oral clonidine: $0.2 \mathrm{mg} 2$ to $4 \mathrm{~h}$ before surgery and then a transdermal clonidine patch (which provided clonidine $0.2 \mathrm{mg} / \mathrm{d}$ ) until $72 \mathrm{~h}$ after surgery

Control group 1

- Placebo: 2 to $4 \mathrm{~h}$ before surgery and then placebo for up to 30 days after surgery

Control group 2 (not included in meta-analyses)

- Placebo: 2 to $4 \mathrm{~h}$ before surgery and then a transdermal placebo patch until $72 \mathrm{~h}$ after surgery

\begin{tabular}{ll}
\hline Outcomes & AKI \\
\hline Notes & Dialysis within 30 days \\
- & Treatment group 2 and control group 2 not included in the meta-analyses (wrong intervention) \\
- Funding source: funding received from the industry. Sponsors of the study had no role in the design \\
and conduct of the study, data collection and analysis or publication. \\
- Financial support provided from Australian National Health and Medical Research Council, the Span- \\
ish Ministry of Health and Social Policy. Study drugs were provided by Boehringer Ingelheim and Bay- \\
er Pharma AG. Boehringer Ingelheim provided an uncertain amount of funding \\
- Up to $10 \%$ of patients included had an eGFR of $45 \mathrm{~mL} /$ min or less at start of the study
\end{tabular}

\section{Risk of bias}

\begin{tabular}{lll}
\hline Bias & Authors' judgement & Support for judgement \\
\hline $\begin{array}{l}\text { Random sequence genera- } \\
\text { tion (selection bias) }\end{array}$ & Low risk & Computerized randomisation \\
\hline $\begin{array}{l}\text { Allocation concealment } \\
\text { (selection bias) }\end{array}$ & Low risk & Concealed allocation \\
\hline $\begin{array}{l}\text { Blinding of participants } \\
\text { and personnel (perfor- } \\
\text { mance bias) }\end{array}$ & Low risk & \\
All outcomes & & $\begin{array}{l}\text { Patients, clinicians, data collectors, and outcome adjudicators were blinded to } \\
\text { the allocation of each intervention. }\end{array}$ \\
\hline
\end{tabular}

Blinding of outcome as- Low risk Patients, clinicians, data collectors, and outcome adjudicators were blinded to sessment (detection bias) the allocation of each intervention.

All outcomes

\begin{tabular}{lll}
\hline $\begin{array}{l}\text { Incomplete outcome data } \\
\text { (attrition bias) } \\
\text { All outcomes }\end{array}$ & Low risk & $\begin{array}{l}\text { Less than } 5 \% \text { missing creatinine values were reported. Multiple imputation } \\
\text { models were used to handle missing data, which all yielded similar results }\end{array}$ \\
\hline $\begin{array}{l}\text { Selective reporting (re- } \\
\text { porting bias) }\end{array}$ & Low risk & Study protocol matches outcomes presented \\
\hline Other bias & Low risk & $\begin{array}{l}\text { Contribution of funding sources unclear, however financial support provided } \\
\text { by two large governmental non-profit organisations. The authors state that the }\end{array}$
\end{tabular}

Effects of peri-operative nonsteroidal anti-inflammatory drugs on post-operative kidney function for adults with normal kidney function 


\begin{tabular}{ll}
\hline Methods & Study design: parallel RCT \\
& - Study duration: not reported \\
& - Study follow-up: 2 POD \\
\hline Participants & Country: UK \\
- Setting: single centre \\
- Inclusion criteria: patients undergoing open oesophagogastrectomy for cancer \\
- Number: treatment group $1(10)$; control group $(10)$ \\
- Sex (M/F): treatment group (9/1); control group $(8 / 2)$ \\
- Exclusion criteria: history of peptic ulceration, asthma, previous reactions to NSAID, allergies, evi- \\
dence of kidney insufficiency, diuretic therapy and recent NSAID ingestion.
\end{tabular}

\begin{tabular}{ll}
\hline Interventions & Treatment group \\
- & Diclofenac: $75 \mathrm{mg}$ IM at induction then 4 doses ( $75 \mathrm{mg}$ each) every $12 \mathrm{~h}$ for $48 \mathrm{~h}$ \\
Control group \\
- Placebo: at induction then 4 doses every $12 \mathrm{~h}$ for $48 \mathrm{~h}$ \\
\hline Outcomes & $\begin{array}{l}\text { Pre-operative and post-operative (day of the surgery, } 1 \text { day after surgery) measurement of } \mathrm{CrCl}, \mathrm{SCr}, \\
\text { urine output, sodium output, potassium output, number of patients on diuretic or dopamine to treat } \\
\text { post-operative kidney insufficiency }\end{array}$ \\
\hline Notes & Funding source: not reported \\
One patient in diclofenac group withdrawn due to low urine output and was later found to have had \\
a reduced preoperative $\mathrm{CrCl}$ (45 $\mathrm{mL} / \mathrm{min}$ ). This patient recovered after IV dopamine and frusemide \\
administration. In this study, frusemide $10 \mathrm{mg}$ IV was given if urine flow rate was $<30 \mathrm{~mL} / \mathrm{h}$ for 2 con- \\
secutive periods of $1 \mathrm{~h}$
\end{tabular}

\section{Risk of bias}

\begin{tabular}{|c|c|c|}
\hline Bias & Authors' judgement & Support for judgement \\
\hline $\begin{array}{l}\text { Random sequence genera- } \\
\text { tion (selection bias) }\end{array}$ & Unclear risk & Study was reported as randomised; method of randomisation not reported \\
\hline $\begin{array}{l}\text { Allocation concealment } \\
\text { (selection bias) }\end{array}$ & Unclear risk & Insufficient information to permit judgement \\
\hline $\begin{array}{l}\text { Blinding of participants } \\
\text { and personnel (perfor- } \\
\text { mance bias) } \\
\text { All outcomes }\end{array}$ & Unclear risk & $\begin{array}{l}\text { Standardised management for intervention and anaesthetic technique and } \\
\text { fluid therapy, however unclear how patients and personnel were blinded. }\end{array}$ \\
\hline $\begin{array}{l}\text { Blinding of outcome as- } \\
\text { sessment (detection bias) } \\
\text { All outcomes }\end{array}$ & Unclear risk & Insufficient information to permit judgement \\
\hline
\end{tabular}

Effects of peri-operative nonsteroidal anti-inflammatory drugs on post-operative kidney function for adults with normal kidney function 
Power 1992 (Continued)

Incomplete outcome data High risk 1 out of 20 patients, randomised to the active study drug group, was with(attrition bias) drawn after $18 \mathrm{~h}$ due to oliguria and severe AKI. It is plausible that the effect is All outcomes enough to induce clinically relevant bias in observed effect size

\begin{tabular}{lll}
\hline $\begin{array}{l}\text { Selective reporting (re- } \\
\text { porting bias) }\end{array}$ & Low risk & Study protocol matches outcomes presented \\
\hline Other bias & Unclear risk & Insufficient information to permit judgement \\
\hline
\end{tabular}

Puolakka 2009

\begin{tabular}{ll}
\hline Methods & Study design: parallel RCT \\
- Study duration: not reported \\
- Study follow-up: $20 \mathrm{~h}$ post-operatively \\
\hline Participants & Country: Finland \\
- Setting: single centre \\
- Inclusion criteria: patients undergoing laparoscopic hysterectomy \\
- Number: treatment group (15); control group (15) \\
- Mean age \pm SD (years): treatment group (48.5 \pm 7.9$)$; control group (50.5 \pm 4.5$)$ \\
- Exclusion criteria: allergy to aspirin-like drugs or sulphonamide; bronchial asthma; liver or kidney dis- \\
turbances; peptic ulcer; bleeding disorder; pregnancy; substance abuse; chronic pain
\end{tabular}

\begin{tabular}{ll}
\hline Interventions & Treatment group \\
- & Parecoxib: single dose of $80 \mathrm{mg}$ IV, before the induction of anaesthesia \\
Control group & Saline \\
\hline Outcomes & $\begin{array}{l}\text { SCr and sensitive urine and serum markers for renal tubular injury directly after induction of anaes- } \\
\text { thesia, } 2 \mathrm{~h} \text { after induction, first and second POD }\end{array}$ \\
\hline Notes & $\begin{array}{l}\text { Post hoc analysis shows that study is underpowered to detect statistically significant serious adverse } \\
\text { events } \\
\text { - Funding source: supported by the Medical Research Fund of Tampere University Hospital, Finland }\end{array}$
\end{tabular}

\section{Risk of bias}

\begin{tabular}{lll}
\hline Bias & Authors' judgement & Support for judgement \\
\hline $\begin{array}{l}\text { Random sequence genera- } \\
\text { tion (selection bias) }\end{array}$ & Low risk & Computer generated randomisation \\
\hline $\begin{array}{l}\text { Allocation concealment } \\
\text { (selection bias) }\end{array}$ & Low risk & Random numbers in opaque envelopes \\
\hline $\begin{array}{l}\text { Blinding of participants } \\
\text { and personnel (perfor- } \\
\text { mance bias) }\end{array}$ & Low risk & Nurse not involved in the study made up the study drugs \\
All outcomes & & \\
\hline
\end{tabular}

Effects of peri-operative nonsteroidal anti-inflammatory drugs on post-operative kidney function for adults with normal kidney function 
Puolakka 2009 (Continued)

Blinding of outcome as- Unclear risk Insufficient information to permit judgement sessment (detection bias)

All outcomes

\begin{tabular}{lll}
$\begin{array}{l}\text { Incomplete outcome data } \\
\text { (attrition bias) } \\
\text { All outcomes }\end{array}$ & Low risk & $\begin{array}{l}\text { No patients withdrawn. Missing data from 2 patients at variable time points. } \\
\text { Missing outcome data balanced in numbers across intervention groups }\end{array}$ \\
\hline $\begin{array}{l}\text { Selective reporting (re- } \\
\text { porting bias) }\end{array}$ & Low risk & Study protocol matches outcomes presented \\
\hline Other bias & Low risk & Non-profit organisation funding received \\
\hline
\end{tabular}

Rafiq 2014

\begin{tabular}{ll}
\hline Methods & Study design: parallel RCT \\
- Study duration: March 2007 to August 2009 \\
- Study follow-up: 30 POD \\
\hline Participants & Country: Denmark \\
- Setting: single centre \\
- Inclusion criteria: patients requiring cardiac surgery (medial sternotomy) \\
- Number: treatment group (77); control group (74) \\
- Mean age \pm SD (years): treatment group (62 \pm 12$)$; control group (64 \pm 13$)$ \\
- Sex (M/F): treatment group (61/16); control group (59/15) \\
ing; chronic pain; SCr $>150 \mu$ mol/L, hepatic disease with elevated liver enzymes; allergic to study med- \\
ication; alcohol abuse; abuse of narcotics or medication; pregnancy; participation in other clinical tri- \\
als; insufficient language skills; ICU stay > 24 h
\end{tabular}

$\begin{array}{ll}\text { Interventions } & \text { Treatment group } \\ \text { - Ketorolac: } 30 \mathrm{mg} \text { IV during extubation, followed by ibuprofen } 400 \mathrm{mg} 4 \text { times/d } \\ \text { Control group } \\ \text { - Morphine: } 10 \mathrm{mg} 4 \text { times/d. }\end{array}$

\begin{tabular}{ll}
\hline Outcomes & Maximum post-operative $\mathrm{SCr}$ and individual rise in $\mathrm{SCr}$ \\
& - Length of hospital stay, death and need for RRT post-operatively \\
\hline Notes & - Funding source: no funding received \\
\hline
\end{tabular}

\section{Risk of bias}

\begin{tabular}{lll}
\hline Bias & Authors' judgement & Support for judgement \\
\hline $\begin{array}{l}\text { Random sequence genera- } \\
\text { tion (selection bias) }\end{array}$ & Unclear risk & $\begin{array}{l}\text { Study was described as randomised, method of randomisation was not report- } \\
\text { ed }\end{array}$ \\
\hline $\begin{array}{l}\text { Allocation concealment } \\
\text { (selection bias) }\end{array}$ & Low risk & Sequentially numbered, opaque sealed envelope \\
\hline
\end{tabular}


Rafiq 2014 (Continued)
Blinding of participants
High risk
Open-label study and personnel (performance bias)

All outcomes

\begin{tabular}{|c|c|c|}
\hline $\begin{array}{l}\text { Blinding of outcome as- } \\
\text { sessment (detection bias) } \\
\text { All outcomes }\end{array}$ & High risk & Open-label study \\
\hline
\end{tabular}

Incomplete outcome data Low risk (attrition bias)

All outcomes

Selective reporting (re-
porting bias)

Other bias Low risk The study appears to be free of other sources of bias

Of 180 randomised patients, 29 patients were withdrawn prior to administration of the study drug. Missing outcome data balanced in numbers across intervention group with similar reasons for missing data across groups

\section{Rapanos 1999}

\begin{tabular}{ll}
\hline Methods & Study design: parallel RCT \\
- Study duration: not reported \\
- Study follow-up: 24 h post-operatively
\end{tabular}

\begin{tabular}{ll}
\hline Participants & Country: Canada \\
- Setting: single centre \\
- Inclusion criteria: adults undergoing elective aortocoronary bypass surgery \\
- Number: treatment group (31); control group (26) \\
- Median age \pm SD (years): treatment group $(62.2 \pm 9.5)$; control group $(59.4 \pm 9.4)$ \\
- Sex (M/F): treatment group (25/6); control group (20/6) \\
- Exclusion criteria: previous history of peptic ulcer or GI bleeding; hepatic or kidney insufficiency; in- \\
sulin dependent DM; known allergy to aspirin or NSAIDs; use of aspirin in the 5 days prior to surgery; \\
gastro-epiploic artery conduit; weight < $60 \mathrm{~kg}$; inability to operate patient controlled analgesia device
\end{tabular}

\section{Risk of bias}

Bias Authors' judgement Support for judgement


Rapanos 1999 (Continued)

Random sequence genera- Low risk Randomisation carried out by pharmacy department tion (selection bias)

$\begin{array}{ll}\begin{array}{l}\text { Allocation concealment } \\ \text { (selection bias) }\end{array} & \text { Low risk }\end{array} \quad \begin{aligned} & \text { Sequential selection of previously randomised envelopes; envelopes contain- } \\ & \text { ing study drug or placebo }\end{aligned}$

Blinding of participants Low risk Study drugs and placebo suppositories in envelopes apearing sim

and personnel (perfor-

mance bias)

All outcomes

Blinding of outcome as-
sessment (detection bias) $\quad$ Unclear risk $\quad$ Study drugs and placebo suppositories in envelopes appearing similar

All outcomes

Incomplete outcome data Low risk Reasons for missing outcome data unlikely to be related to true outcome
(attrition bias)

All outcomes

\begin{tabular}{lll}
\hline $\begin{array}{l}\text { Selective reporting (re- } \\
\text { porting bias) }\end{array}$ & Low risk & Study protocol matches outcomes presented \\
\hline Other bias & Low risk & The study appears to be free of other sources of bias \\
\hline
\end{tabular}

Slaven 1998

\begin{tabular}{|c|c|}
\hline Methods & $\begin{array}{l}\text { - Study design: parallel RCT } \\
\text { - Study duration: not reported } \\
\text { - Study follow-up: } 6 \mathrm{~h}\end{array}$ \\
\hline Participants & $\begin{array}{l}\text { - Country: New Zealand } \\
\text { - Setting: single centre } \\
\text { - Inclusion criteria: healthy as judged by medical history, physical examination, routine biochemical } \\
\text { and haematological screening and were rated as American Society of Anaesthesiologists (ASA) classi- } \\
\text { fication undergoing elective lower back surgery (laminectomies) } \\
\text { - Number: treatment group (10); control group (10) } \\
\text { - Mean age } \pm \text { SD (years): treatment group (39.6 } \pm 14.1) \text {; control group }(38.3 \pm 7.2) \\
\text { - Sex (M/F): treatment group (10/0); control group }(6 / 4) \\
\text { - Exclusion criteria: not reported }\end{array}$ \\
\hline
\end{tabular}

\begin{tabular}{ll}
\hline Interventions & Treatment group \\
& - Tenoxicam: $40 \mathrm{mg}$ IV prior to induction \\
& Control group \\
& $\bullet$ Placebo: IV prior to induction \\
\hline Outcomes & Urinary CrCl, osmolar clearance and free water clearance \\
\hline Notes & Funding source: tenoxicam-placebo gift from Roche Products New Zealand Ltd
\end{tabular}

\section{Risk of bias}

Bias Authors' judgement Support for judgement

Effects of peri-operative nonsteroidal anti-inflammatory drugs on post-operative kidney function for adults with normal kidney function 
Slaven 1998 (Continued)

Random sequence genera- Unclear risk Randomisation performed by pharmacist, randomisation technique unknown tion (selection bias)

Allocation concealment Unclear risk Insufficient information to permit judgement
(selection bias)

(selection bias)

$\begin{array}{ll}\begin{array}{l}\text { Blinding of participants } \\ \text { and personnel (perfor- }\end{array} & \text { Low risk }\end{array}$

mance bias)

All outcomes

\begin{tabular}{lll}
$\begin{array}{l}\text { Blinding of outcome as- } \\
\text { sessment (detection bias) } \\
\text { All outcomes }\end{array}$ & Unclear risk & Insufficient information to permit judgement \\
\hline $\begin{array}{l}\text { Incomplete outcome data } \\
\text { (attrition bias) } \\
\text { All outcomes }\end{array}$ & Unclear risk & Insufficient information to permit judgement \\
\hline $\begin{array}{l}\text { Selective reporting (re- } \\
\text { porting bias) }\end{array}$ & Low risk & Study protocol matches outcomes presented \\
\hline $\begin{array}{l}\text { Other bias } \\
\text { Low risk }\end{array}$ & $\begin{array}{l}\text { The tenocixam-placebo was a gift from Roche Products New Zealand (the } \\
\text { manufacturer). The study design and analysis of the results were independent } \\
\text { of any pharmaceutical company involvement. }\end{array}$
\end{tabular}

Turner 1994

\begin{tabular}{|c|c|}
\hline Methods & $\begin{array}{l}\text { - Study design: parallel RCT } \\
\text { - Study duration: not reported } \\
\text { - Study follow-up: } 3 \text { POD }\end{array}$ \\
\hline Participants & $\begin{array}{l}\text { - Country: Australia } \\
\text { - Setting: single centre } \\
\text { - Inclusion criteria: patients undergoing elective open cholecystectomy } \\
\text { - Number: treatment group (24); control group (24) } \\
\text { - Mean age } \pm \text { SD (years): treatment group ( } 56.5 \pm 16.6) \text {; control group }(49.0 \pm 15.3) \\
\text { - Sex (M/F): treatment group (8/16); control group (10/14) } \\
\text { - Exclusion criteria: history of peptic ulceration; bleeding disorder; kidney impairment; haemorrhoids }\end{array}$ \\
\hline Interventions & $\begin{array}{l}\text { Treatment group } \\
\text { - Indomethacin suppositories: } 200 \mathrm{mg} \text { at end of surgery then } 100 \mathrm{mg} \text { twice daily for } 3 \text { days } \\
\text { Control group } \\
\text { - Placebo suppositories: according to same treatment regimen. }\end{array}$ \\
\hline Outcomes & - Pre-operative and post-operative (48 h) SCr was measured in 19/50 patients \\
\hline Notes & $\begin{array}{l}\text { - No pre-operative and post-operative } \mathrm{SCr} \text { measures given, rather the mean change was given for each } \\
\text { group } \\
\text { - Funding Source: not reported }\end{array}$ \\
\hline
\end{tabular}

\section{Risk of bias}

Effects of peri-operative nonsteroidal anti-inflammatory drugs on post-operative kidney function for adults with normal kidney function 47 (Review)

Copyright (c) 2018 The Cochrane Collaboration. Published by John Wiley \& Sons, Ltd. 
Turner 1994 (Continued)

\begin{tabular}{|c|c|c|}
\hline Bias & Authors' judgement & Support for judgement \\
\hline $\begin{array}{l}\text { Random sequence genera- } \\
\text { tion (selection bias) }\end{array}$ & Unclear risk & $\begin{array}{l}\text { Study was described as randomised, method of randomisation was not report- } \\
\text { ed }\end{array}$ \\
\hline $\begin{array}{l}\text { Allocation concealment } \\
\text { (selection bias) }\end{array}$ & Low risk & $\begin{array}{l}\text { Sequential selection of previously randomised envelopes, study drugs appear- } \\
\text { ing identical }\end{array}$ \\
\hline $\begin{array}{l}\text { Blinding of participants } \\
\text { and personnel (perfor- } \\
\text { mance bias) } \\
\text { All outcomes }\end{array}$ & Low risk & Patients, nursing staff and medical staff were blinded \\
\hline $\begin{array}{l}\text { Blinding of outcome as- } \\
\text { sessment (detection bias) } \\
\text { All outcomes }\end{array}$ & Low risk & Patients, nursing staff and medical staff were blinded \\
\hline $\begin{array}{l}\text { Incomplete outcome data } \\
\text { (attrition bias) } \\
\text { All outcomes }\end{array}$ & Unclear risk & $\begin{array}{l}50 \text { patients were included in the study, } 2 \text { patients were withdrawn due to pro- } \\
\text { tocol violation. Of the remaining } 48 \text { patients kidney outcome data was avail- } \\
\text { able from } 38 \text { patients ( } 11 \% \text { missing data). No reasons for missing data was } \\
\text { provided }\end{array}$ \\
\hline $\begin{array}{l}\text { Selective reporting (re- } \\
\text { porting bias) }\end{array}$ & Low risk & Study protocol matches outcomes presented \\
\hline Other bias & Unclear risk & Insufficient information to permit judgement \\
\hline
\end{tabular}

\section{Varrassi 1994}

\begin{tabular}{ll}
\hline Methods & Study design: parallel RCT \\
& - Study duration: not reported \\
& - Study follow-up: $24 \mathrm{~h}$ post-operatively \\
\hline Participants & Country: Italy \\
- Setting: single centre \\
- Inclusion criteria: patients undergoing elective cholecystectomy \\
- Number: treatment group (48); control group (47) \\
- Mean age \pm SE (years): treatment group (52.5 \pm 1.4$) ;$ control group $(50.2 \pm 1.6)$ \\
- Sex (M/F): treatment group (17/31); control group (15/32) \\
\end{tabular}

- Ketorolac: $30 \mathrm{mg}$ IM before surgery then $2 \mathrm{mg} / \mathrm{h}$ IV infusion for $24 \mathrm{~h}$

Control group

- Normal saline: $1 \mathrm{~mL}$ IM then $2 \mathrm{~mL} / \mathrm{h}$ IV infusion for $24 \mathrm{~h}$

\begin{tabular}{ll}
\hline Outcomes & Post-operative SCr \\
\hline Notes & - Funding Source: supported in part by CNR Grants \\
& - SCr level taken in recovery (and after first IM injection of ketorolac/placebo) is used as baseline SCr \\
& level. No pre-operative SCr reported
\end{tabular}

Effects of peri-operative nonsteroidal anti-inflammatory drugs on post-operative kidney function for adults with normal kidney function 48 
Varrassi 1994 (Continued)

Risk of bias

\begin{tabular}{|c|c|c|}
\hline Bias & Authors' judgement & Support for judgement \\
\hline $\begin{array}{l}\text { Random sequence genera- } \\
\text { tion (selection bias) }\end{array}$ & Unclear risk & $\begin{array}{l}\text { Study was described as randomised, method of randomisation was not report- } \\
\text { ed }\end{array}$ \\
\hline $\begin{array}{l}\text { Allocation concealment } \\
\text { (selection bias) }\end{array}$ & Unclear risk & Insufficient information to permit judgement \\
\hline $\begin{array}{l}\text { Blinding of participants } \\
\text { and personnel (perfor- } \\
\text { mance bias) } \\
\text { All outcomes }\end{array}$ & Unclear risk & Insufficient information to permit judgement \\
\hline $\begin{array}{l}\text { Blinding of outcome as- } \\
\text { sessment (detection bias) } \\
\text { All outcomes }\end{array}$ & Unclear risk & Insufficient information to permit judgement \\
\hline $\begin{array}{l}\text { Incomplete outcome data } \\
\text { (attrition bias) } \\
\text { All outcomes }\end{array}$ & Low risk & $\begin{array}{l}5 \text { out of } 100 \text { patients were withdrawn from the study after randomisation and } \\
\text { administration of the study drug. Reasons for missing outcome data unlikely } \\
\text { to be related to true outcome }\end{array}$ \\
\hline $\begin{array}{l}\text { Selective reporting (re- } \\
\text { porting bias) }\end{array}$ & Low risk & Study protocol matches outcomes presented \\
\hline Other bias & Unclear risk & Insufficient information to permit judgement \\
\hline
\end{tabular}

AKI - acute kidney injury; ASA - American Society of Anesthesiologists; CrCl - creatinine clearance; DM - diabetes mellitus; eGFR estimated glomerular filtration rate; ESKD - end-stage kidney disease; GI - gastrointestinal; ICU - intensive care unit; IM - intramuscular; IV - intravenous; MI - myocardial infarction; NSAIDs - nonsteroidal anti-inflammatory drugs; POD - post-operative day/s; RRT - renal replacement therapy; $\mathrm{SCr}$ - serum creatinine

Characteristics of excluded studies [ordered by study ID]

\begin{tabular}{ll}
\hline Study & Reason for exclusion \\
\hline Castiglione 1997 & Wrong control group: control group also received ketorolac \\
\hline Cheruku 2004 & $\begin{array}{l}\text { Wrong population: patients included with a SCr up to } 2.0 \mathrm{mg} / \mathrm{dL} \\
\text { Insufficient post-operative outcome measures reported; kidney function given for } 3 / 100 \text { patients } \\
\text { only; all of those had a SCr above } 2.0 \mathrm{mg} / \mathrm{dL}\end{array}$ \\
\hline Chow 2001 & $\begin{array}{l}\text { Wrong population: one third of patients underwent a nephrectomy; patients were excluded when a } \\
\text { significant SCr rise was noted }\end{array}$ \\
\hline Daniels 2014 & Abstract-only publication; no kidney function outcome measures documented \\
\hline Doyle 1998 & Wrong control group: patients randomised to 2 analgesic regimens \\
\hline Fredman 1999 & No relevant post-operative kidney outcome measures \\
\hline Grimsby 2012 & $\begin{array}{l}\text { Wrong population: patients with CKD were included and } 111 / 128 \text { patients underwent a nephrecto- } \\
\text { my }\end{array}$ \\
\hline
\end{tabular}

Effects of peri-operative nonsteroidal anti-inflammatory drugs on post-operative kidney function for adults with normal kidney function 


\begin{tabular}{|c|c|}
\hline Study & Reason for exclusion \\
\hline Hynes 2006 & No relevant post-operative kidney outcome measures \\
\hline Leeson 2007 & Kidney function parameters not clearly defined \\
\hline Ma 2015 & No kidney function parameters documented \\
\hline Merry 2002 & Wrong population: patients with CKD included \\
\hline \multirow[t]{2}{*}{ Nussmeier 2005} & Included $6(1 \%)$ of patients with kidney insufficiency. \\
\hline & $\begin{array}{l}\text { Post-operative kidney failure or dysfunction reported at any time during the } 30 \text { days after surgery. } \\
\text { No data given for the first } 2 \text { days after surgery }\end{array}$ \\
\hline \multirow[t]{2}{*}{ Nussmeier 2006} & $\begin{array}{l}\text { Patients were included when kidney disease was deemed significant by the investigator; } 6 \text { patients } \\
\text { had kidney insufficiency (unknown eGFR) on randomisation. }\end{array}$ \\
\hline & Adverse events were recorded. No SCr or urine output individually reported \\
\hline Nuutinen 1991 & No concise kidney outcome measures reported \\
\hline Parker 1994 & No concise kidney outcome measures reported \\
\hline Rao 2000 & $\begin{array}{l}\text { Ambiguity regarding inclusion criteria. Patients excluded when 'significant renal disease' was } \\
\text { present. No concise kidney outcomes documented; } 1 \text { patient developed transient kidney failure }\end{array}$ \\
\hline Ready 1994 & No concise kidney outcome measures reported \\
\hline Southworth 2009 & No concise kidney outcome measures reported \\
\hline Varrassi 1999 & $\begin{array}{l}\text { No concise kidney outcomes measures reported; comment made that there was not statistically } \\
\text { significant difference between treatment groups }\end{array}$ \\
\hline
\end{tabular}

CKD - chronic kidney disease; $\mathrm{CrCl}$ - creatinine clearance; eGFR - estimated glomerular filtration rate; $\mathrm{SCr}$ - serum creatinine

\section{DATA AND ANALYSES}

\section{Comparison 1. Acute kidney injury}

\begin{tabular}{lllll}
\hline $\begin{array}{l}\text { Outcome or subgroup } \\
\text { title }\end{array}$ & $\begin{array}{l}\text { No. of } \\
\text { studies }\end{array}$ & $\begin{array}{l}\text { No. of partici- } \\
\text { pants }\end{array}$ & Statistical method & Effect size \\
\hline $1 \mathrm{AKI}$ & 2 & 7066 & Risk Ratio (M-H, Random, 95\% Cl) & $1.79[0.40,7.96]$ \\
\hline
\end{tabular}

Analysis 1.1. Comparison 1 Acute kidney injury, Outcome 1 AKI.

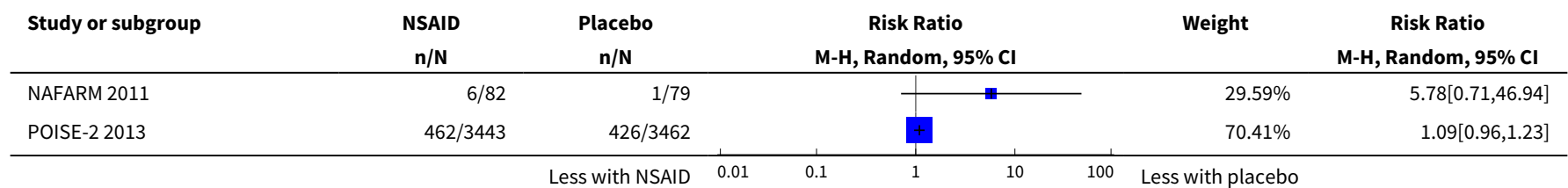




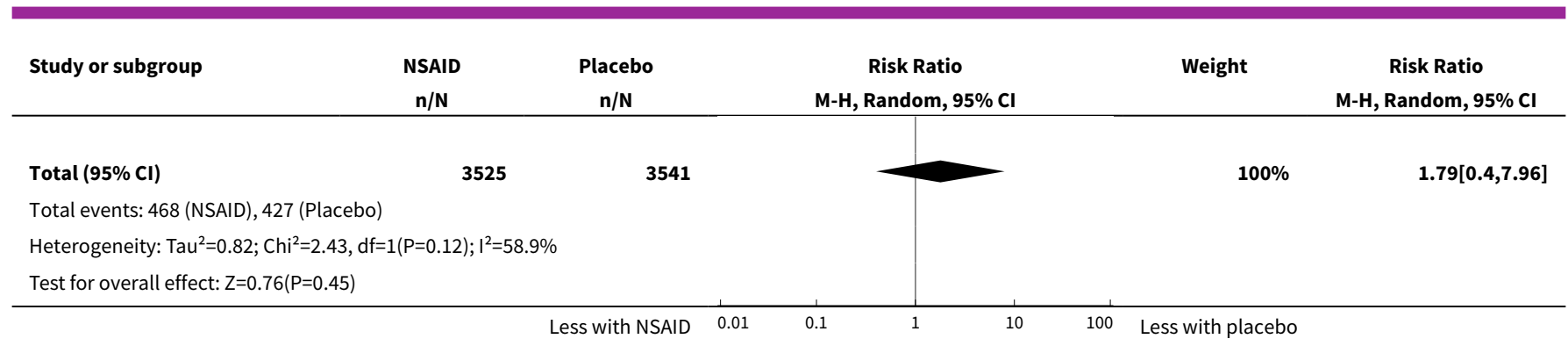

\section{Comparison 2. Serum creatinine}

\begin{tabular}{|c|c|c|c|c|}
\hline Outcome or subgroup title & $\begin{array}{l}\text { No. of } \\
\text { studies }\end{array}$ & $\begin{array}{l}\text { No. of } \\
\text { partici- } \\
\text { pants }\end{array}$ & Statistical method & Effect size \\
\hline 1 Serum creatinine (all studies) & 15 & 794 & Mean Difference (IV, Random, 95\% CI) & $3.23[-0.80,7.26]$ \\
\hline $\begin{array}{l}2 \text { Serum creatinine (excluding high risk of } \\
\text { bias) }\end{array}$ & 7 & 429 & Mean Difference (IV, Random, 95\% CI) & $2.64[-1.28,6.55]$ \\
\hline $\begin{array}{l}3 \text { Serum creatinine (excluding high attri- } \\
\text { tion bias) }\end{array}$ & 11 & 601 & Mean Difference (IV, Random, 95\% CI) & $2.96[-1.57,7.49]$ \\
\hline $\begin{array}{l}4 \text { Serum creatinine (excluding high risk of } \\
\text { bias or high attrition bias) }\end{array}$ & 6 & 331 & Mean Difference (IV, Random, 95\% CI) & $3.57[-1.35,8.48]$ \\
\hline
\end{tabular}

Analysis 2.1. Comparison 2 Serum creatinine, Outcome 1 Serum creatinine (all studies).

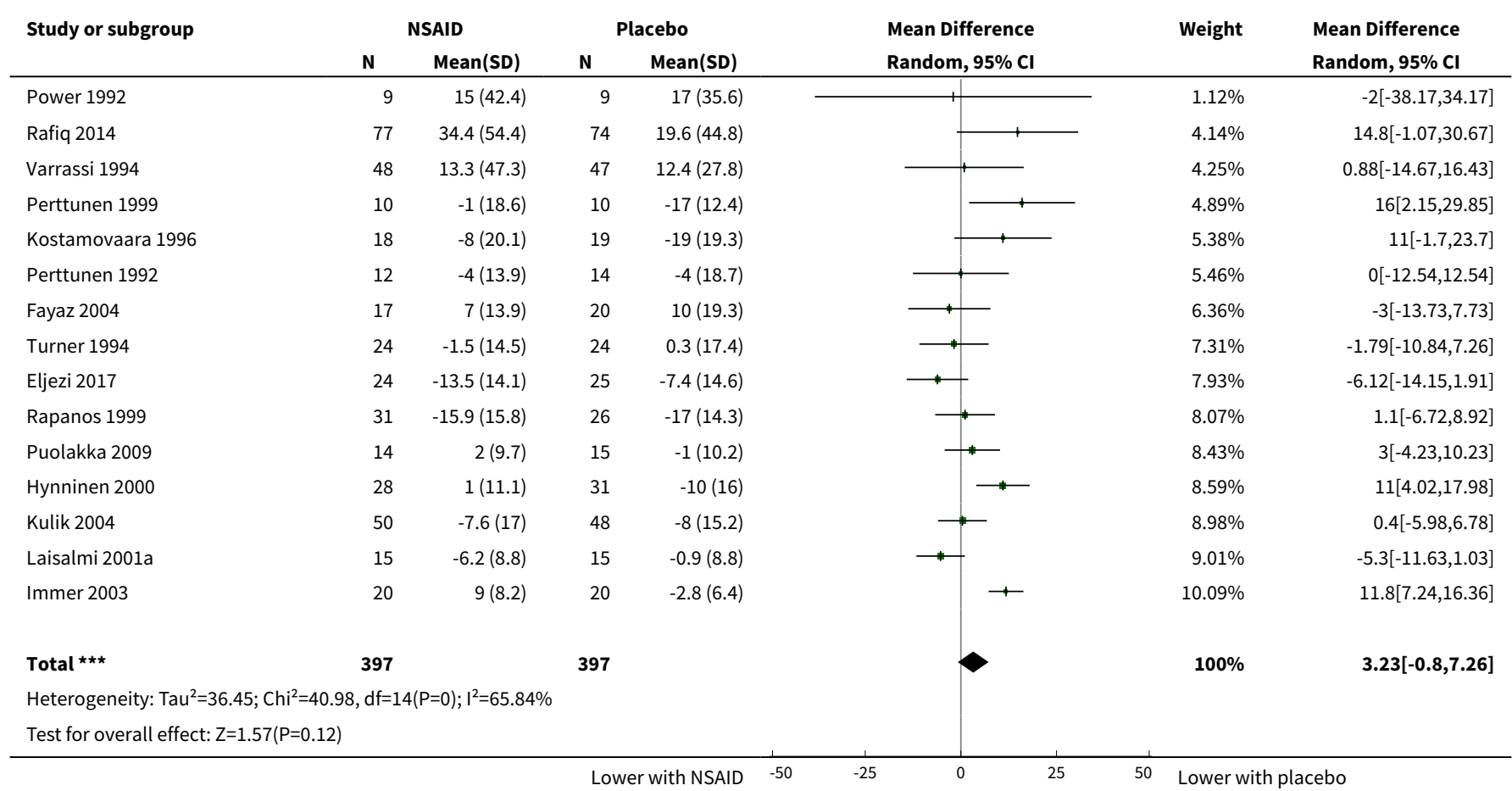


Analysis 2.2. Comparison 2 Serum creatinine, Outcome 2 Serum creatinine (excluding high risk of bias).

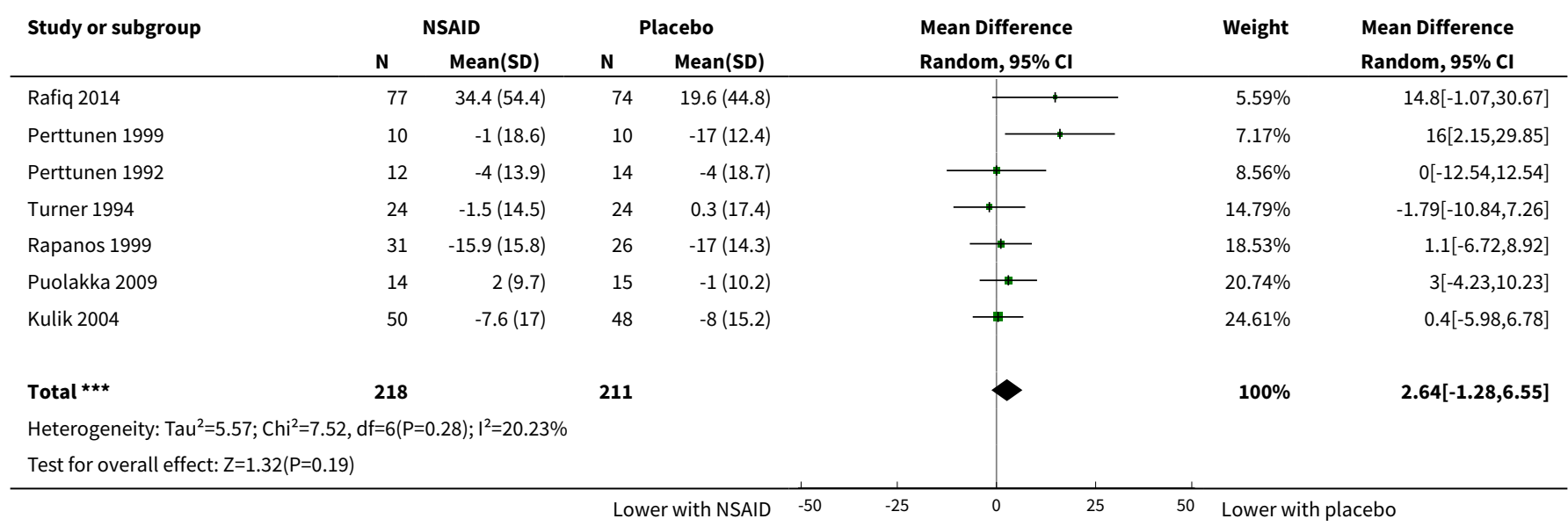

Analysis 2.3. Comparison 2 Serum creatinine, Outcome 3 Serum creatinine (excluding high attrition bias).

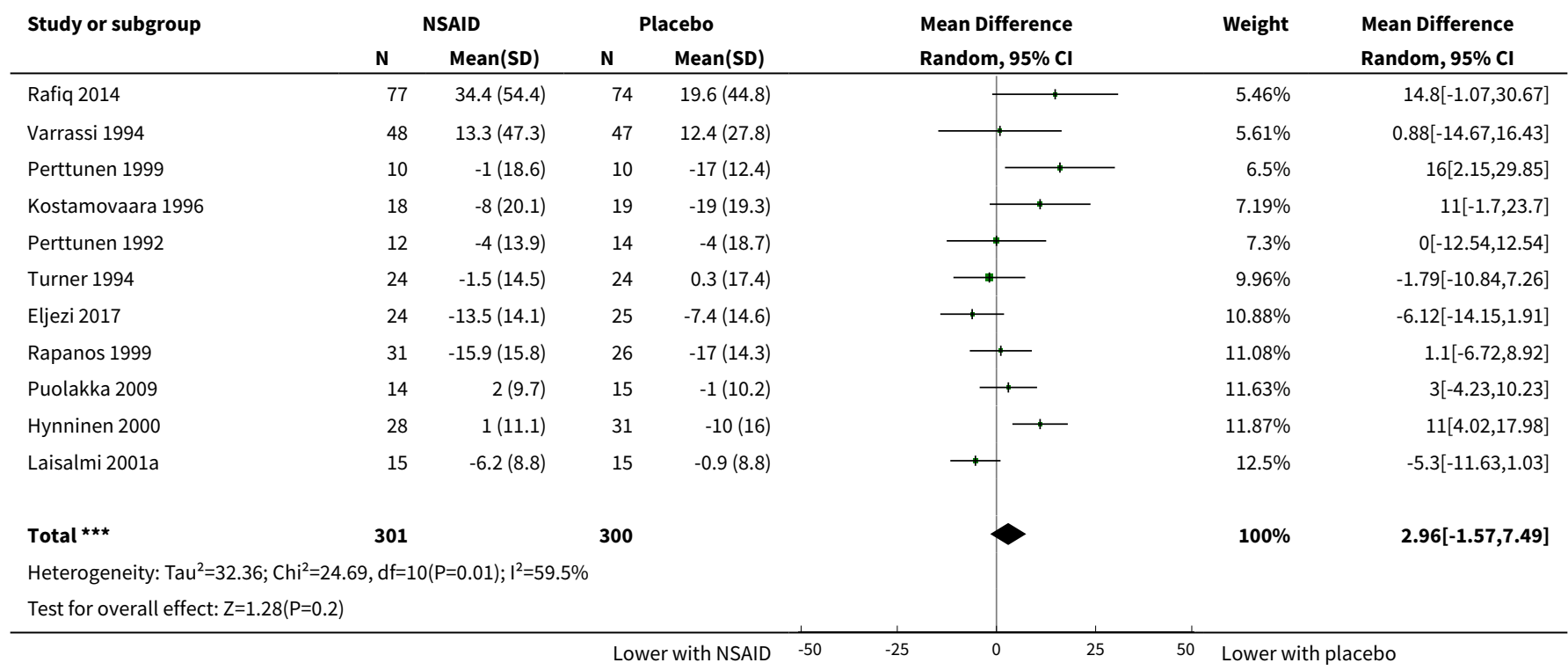

Analysis 2.4. Comparison 2 Serum creatinine, Outcome 4 Serum creatinine (excluding high risk of bias or high attrition bias).

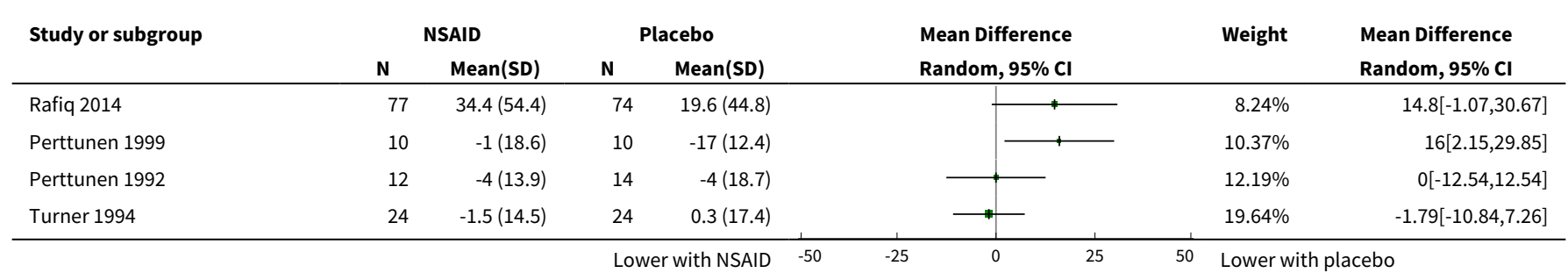

Effects of peri-operative nonsteroidal anti-inflammatory drugs on post-operative kidney function for adults with normal kidney function 52 (Review)

Copyright (c) 2018 The Cochrane Collaboration. Published by John Wiley \& Sons, Ltd. 


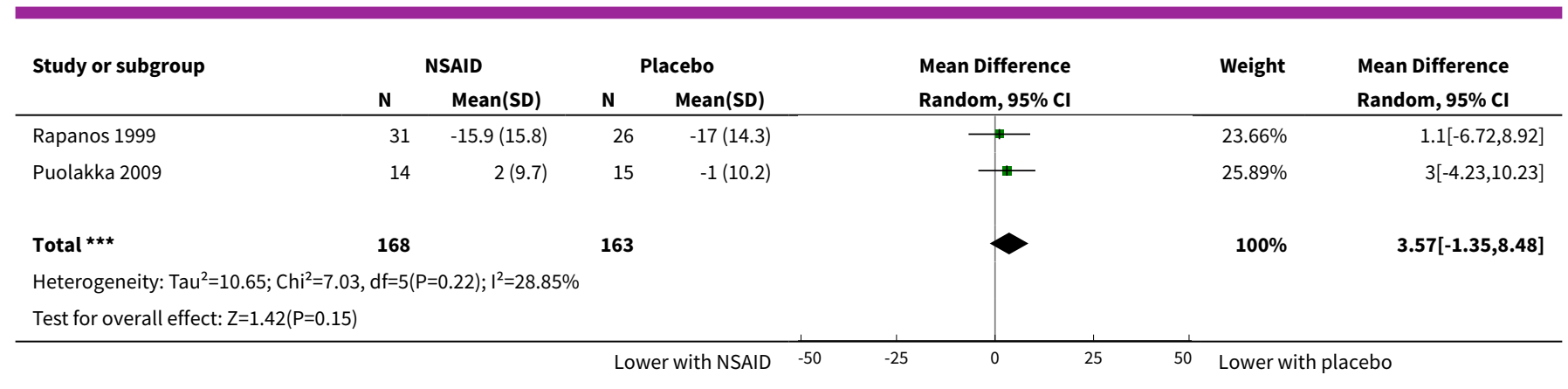

\section{Comparison 3. Urine output}

\begin{tabular}{llllll}
\hline Outcome or subgroup title & $\begin{array}{l}\text { No. of } \\
\text { studies }\end{array}$ & $\begin{array}{l}\text { No. of partici- } \\
\text { pants }\end{array}$ & Statistical method & Effect size \\
\hline 1 Urine output & 6 & 149 & Std. Mean Difference (IV, Random, 95\% Cl) & $-0.49[-1.21,0.24]$ \\
\hline
\end{tabular}

Analysis 3.1. Comparison 3 Urine output, Outcome 1 Urine output.

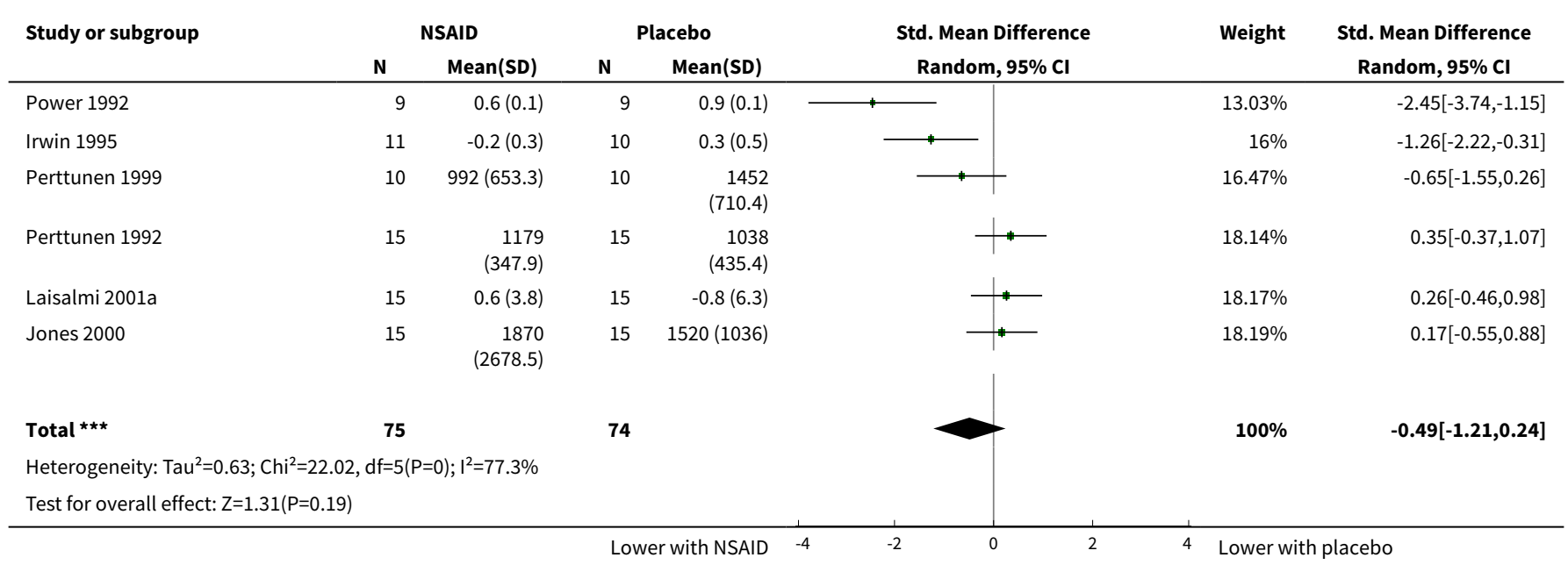

\section{Comparison 4. Need for renal replacement therapy}

\begin{tabular}{lllll}
\hline $\begin{array}{l}\text { Outcome or subgroup } \\
\text { title }\end{array}$ & $\begin{array}{l}\text { No. of } \\
\text { studies }\end{array}$ & $\begin{array}{l}\text { No. of partici- } \\
\text { pants }\end{array}$ & Statistical method & Effect size \\
\hline 1 RRT & 2 & 7056 & Risk Ratio (M-H, Random, 95\% Cl) & $1.57[0.49,5.07]$ \\
\hline
\end{tabular}


Analysis 4.1. Comparison 4 Need for renal replacement therapy, Outcome 1 RRT.

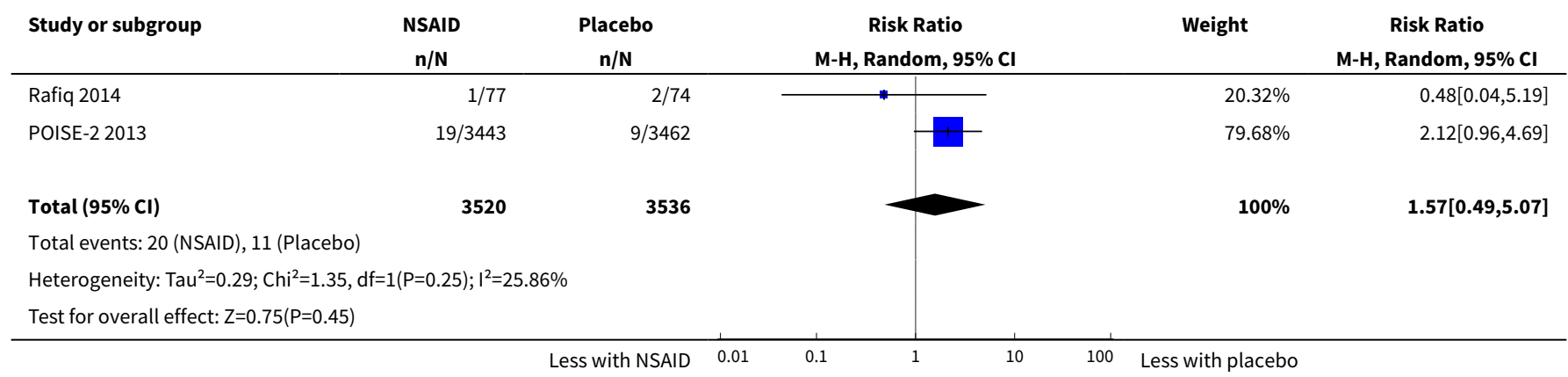

Comparison 5. Death due to any cause

\begin{tabular}{lllll}
\hline Outcome or subgroup title & $\begin{array}{l}\text { No. of } \\
\text { studies }\end{array}$ & $\begin{array}{l}\text { No. of partici- } \\
\text { pants }\end{array}$ & Statistical method & Effect size \\
\hline 1 Death due to any cause & 2 & 312 & Risk Ratio (M-H, Random, 95\% Cl) & $1.44[0.19,11.12]$ \\
\hline
\end{tabular}

Analysis 5.1. Comparison 5 Death due to any cause, Outcome 1 Death due to any cause.

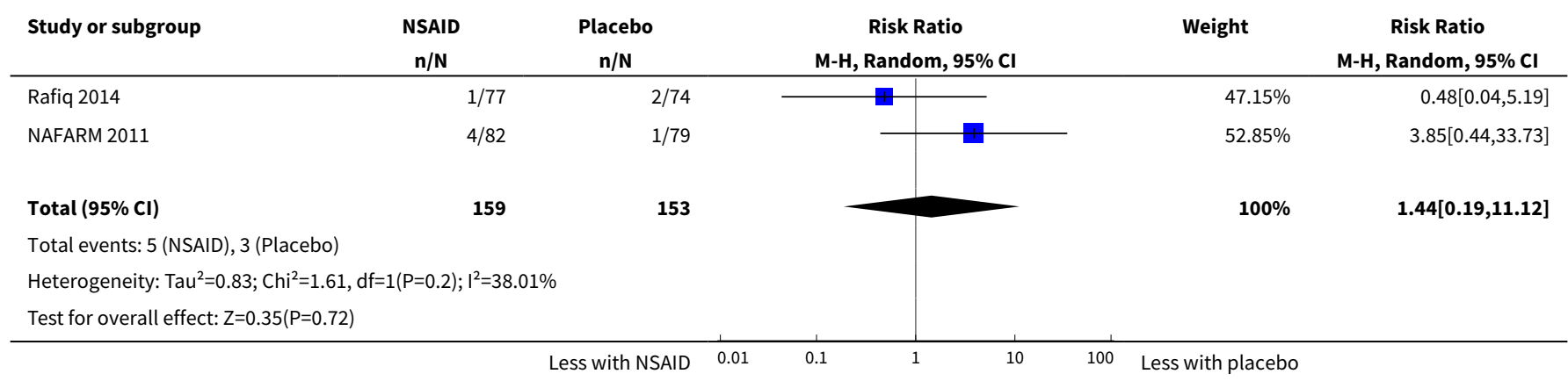

\section{Comparison 6. Length of hospital stay}

\begin{tabular}{lllll}
\hline Outcome or subgroup title & $\begin{array}{l}\text { No. of } \\
\text { studies }\end{array}$ & $\begin{array}{l}\text { No. of partici- } \\
\text { pants }\end{array}$ & Statistical method & Effect size \\
\hline 1 Length of hospital stay & 3 & 410 & Mean Difference (IV, Random, 95\% Cl) & $0.12[-0.48,0.72]$ \\
\hline
\end{tabular}

Analysis 6.1. Comparison 6 Length of hospital stay, Outcome 1 Length of hospital stay.

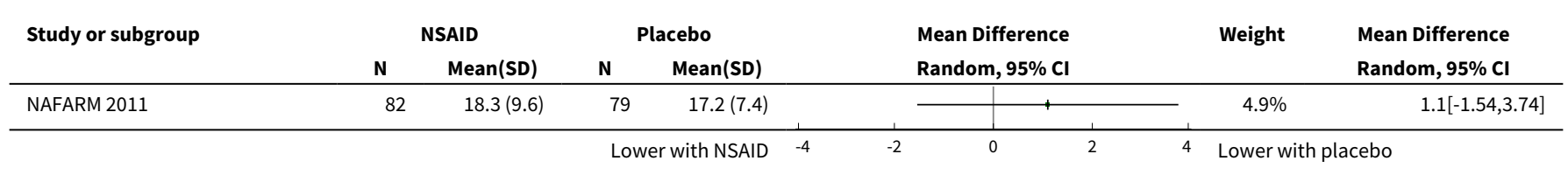

Effects of peri-operative nonsteroidal anti-inflammatory drugs on post-operative kidney function for adults with normal kidney function 54 (Review)

Copyright (c) 2018 The Cochrane Collaboration. Published by John Wiley \& Sons, Ltd. 


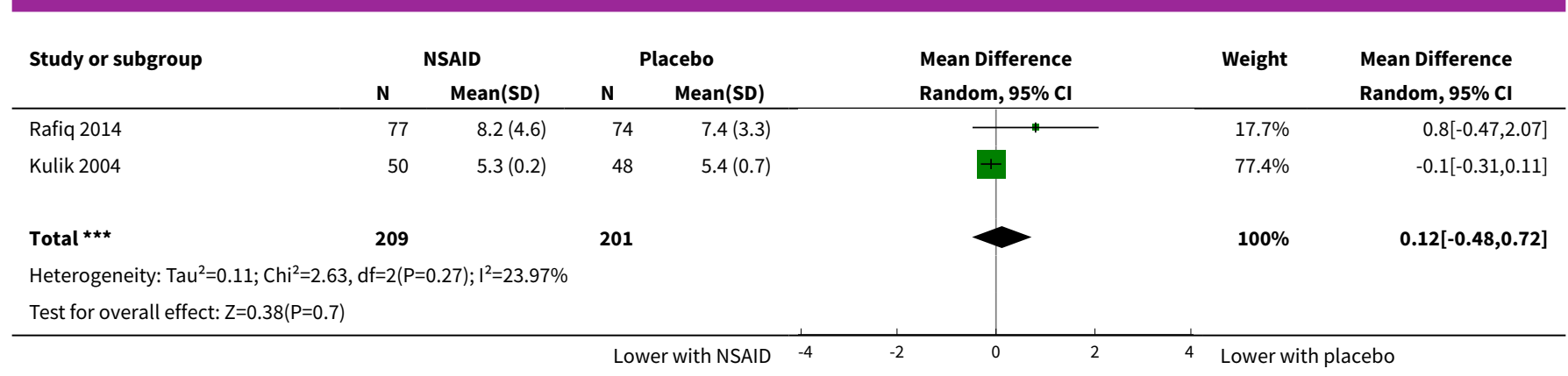

ADDITIONAL TABLES

Table 1. Effect modifiers for meta-regression of change in post-operative serum creatinine

\begin{tabular}{|c|c|c|c|}
\hline Study ID & Cardiac surgery & $\begin{array}{l}\text { NSAIDs > } 24 \\
\text { hours }\end{array}$ & Age exclusion \\
\hline Eljezi 2017 & Yes & Yes & $>75$ years \\
\hline Fayaz 2004 & Yes & No & None reported \\
\hline Hynninen 2000 & Yes & No & $>75$ years \\
\hline Immer 2003 & Yes & Yes, 3 days & $>70$ years \\
\hline Kostamovaara 1996 & No, hip or knee replacement & No & None reported \\
\hline Kulik 2004 & Yes & Yes, 5 days & None reported \\
\hline Laisalmi 2001a & No, breast surgery & No & None reported \\
\hline Perttunen 1992 & No, thoracoscopy & Yes, 2 days & $>75$ years \\
\hline Perttunen 1999 & No, thoracoscopy & Yes, 2 days & $>75$ years \\
\hline Power 1992 & No, oesophagogastrectomy & Yes, 2 days & None reported \\
\hline Puolakka 2009 & No, laparoscopic hysterectomy & No & None reported \\
\hline Rafiq 2014 & Yes & Yes, 4 days & None reported \\
\hline Rapanos 1999 & Yes & No & None reported \\
\hline Turner 1994 & No, cholecystectomy & Yes, 3 days & None reported \\
\hline Varrassi 1994 & No, cholecystectomy & No & $>65$ years \\
\hline
\end{tabular}

NSAIDs - nonsteroidal anti-inflammatory drugs 


\section{APPENDICES}

\section{Appendix 1. Electronic search strategies}

\section{Database}

CENTRAL

\section{Search terms}

1. MeSH descriptor: [Anti-Inflammatory Agents, Non-Steroidal] explode all trees

2. ((non-steroidal next anti-inflammatory) next (agent* ${ }^{*}$ or drug $\left.\left.^{\star}\right)\right):$ ti,ab,kw

3. ((nonsteroidal next anti-inflammatory) next (agent* or drug $\left.\left.{ }^{\star}\right)\right)$ :ti,ab,kw

4. ((non-steroidal next antiinflammatory) next (agent ${ }^{\star}$ or drug*)):ti,ab,kw

5. ((nonsteroidal next antiinflammatory) next (agent* or drug $\left.\left.{ }^{\star}\right)\right)$ :ti,ab,kw

6. NSAID*:ti,ab,kw

7. ((cox 2 inhibitor $\left.{ }^{\star}\right)$ or (cox-2 inhibitor $\left.\left.{ }^{\star}\right)\right): t i, a b, k w$

8. (cyclooxygenase near/2 Inhibitor $\left.{ }^{\star}\right): \mathrm{ti}, \mathrm{ab}, \mathrm{kw}$

9. apazone:ti,ab,kw

10.aspirin:ti,ab,kw

11.clonixin:ti,ab,kw

12.diclofenac:ti,ab,kw

13. diflunisal:ti,ab, kw

14.epirizole:ti,ab,kw

15.fenoprofen:ti,ab,kw

16.feprazone:ti,ab,kw

17.flurbiprofen:ti,ab,kw

18.ibuprofen:ti,ab,kw

19.indomethacin:ti,ab,kw

20.ketoprofen:ti,ab,kw

21.ketorolac:ti,ab,kw

22. meclofenamic acid:ti,ab,kw

23. mefenamic acid:ti,ab,kw

24.naproxen:ti,ab,kw

25.niflumic acid:ti,ab,kw

26.phenylbutazone:ti,ab,kw

27.piroxicam:ti,ab,kw

28.salicylates:ti,ab,kw

29.sulindac:ti,ab,kw

30.tolmetin:ti,ab,kw

31.celecoxib:ti,ab,kw

32.etodolac:ti,ab,kw

33. meloxicam:ti,ab,kw

34. parecoxib:ti,ab,kw

35. rofecoxib:ti,ab,kw

36.tenoxicam:ti,ab,kw

37.valdecoxib:ti,ab,kw

38. $\{$ or \#1-\#37\}

39. analgesi*:ti,ab,kw

40.an ${ }^{*}$ esthesia:ti,ab,kw

41.pain:ti,ab,kw

42. (peri-operativ ${ }^{\star}$ or perioperativ $\left.{ }^{\star}\right): t i, a b, k w$

43. (postoperativ* or post-operativ $\left.{ }^{\star}\right)$ :ti,ab,kw

44. (preoperativ* or pre-operativ $\left.{ }^{\star}\right): t i, a b, k w$

45. $\{$ or \#39-\#44\} 
(Continued)

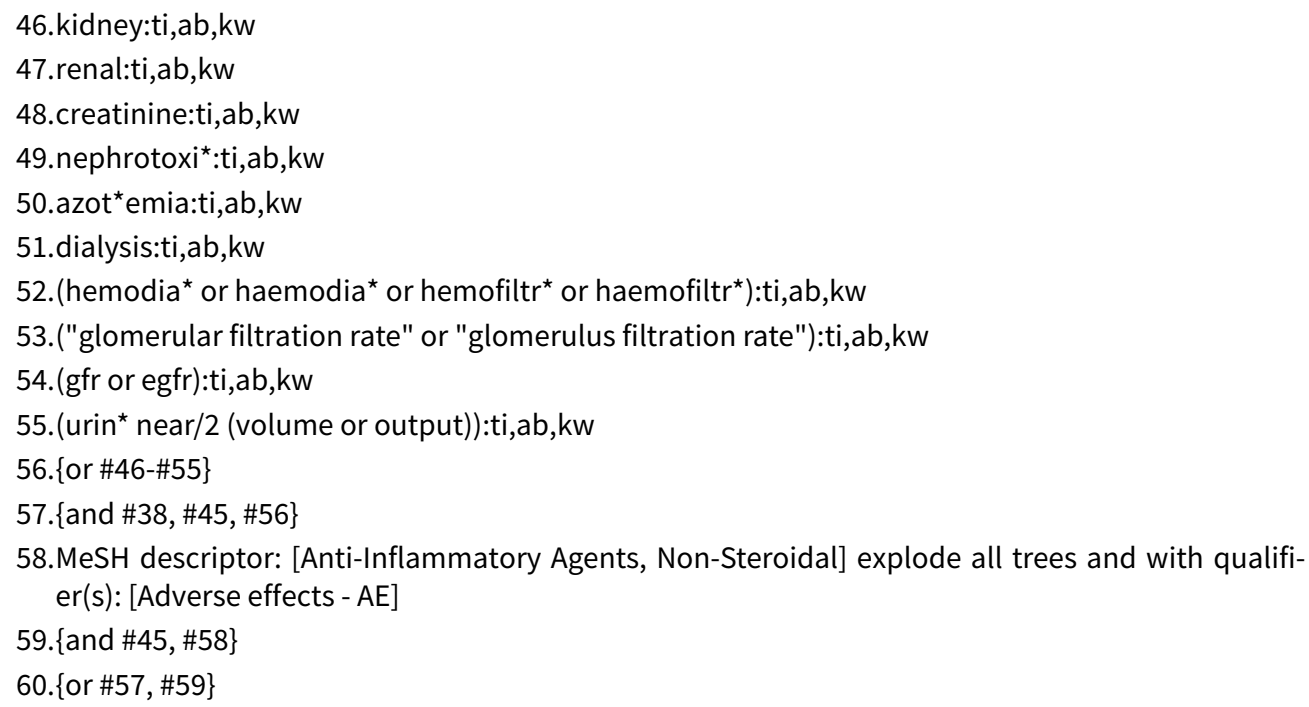

2. (non-steroidal anti-inflammatory adj (agent* or drug $\left.{ }^{\star}\right)$ ).tw.

3. (nonsteroidal anti-inflammatory adj (agent* or drug*)).tw.

4. (non-steroidal antiinflammatory adj (agent ${ }^{\star}$ or drug dr $\left.^{\star}\right)$.tw.

5. (nonsteroidal antiinflammatory adj (agent ${ }^{\star}$ or drug*)).tw.

6. NSAID*.tw.

7. $\operatorname{cox} 2$ inhibitor ${ }^{\star}$.tw.

8. (cyclooxygenase adj2 Inhibitor ${ }^{\star}$ ).tw.

9. apazone.tw.

10.aspirin.tw.

11.clonixin.tw.

12.diclofenac.tw.

13.diflunisal.tw.

14.epirizole.tw.

15.fenoprofen.tw.

16.feprazone.tw.

17.flurbiprofen.tw.

18.ibuprofen.tw.

19.indomethacin.tw.

20.ketoprofen.tw.

21.ketorolac.tw.

22. meclofenamic acid.tw.

23. mefenamic acid.tw.

24.naproxen.tw.

25.niflumic acid.tw.

26. phenylbutazone.tw.

27. piroxicam.tw.

28.salicylates.tw.

29.sulindac.tw.

30.tolmetin.tw.

31.celecoxib.tw.

32.etodolac.tw.

33.tenoxicam.tw.

34. parecoxib.tw.

35.rofecoxib.tw.

Effects of peri-operative nonsteroidal anti-inflammatory drugs on post-operative kidney function for adults with normal kidney function 


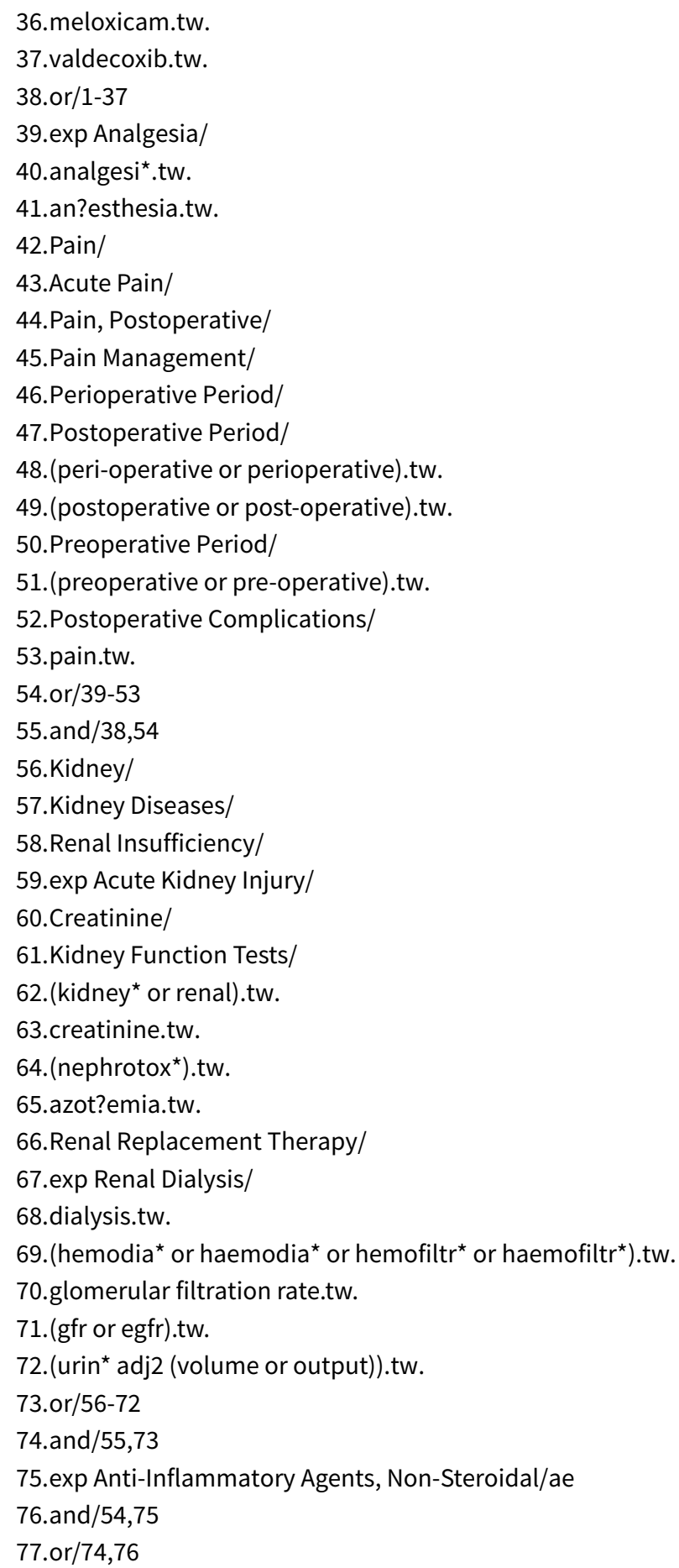

1. exp nonsteroid antiinflammatory agent/

2. (non-steroidal anti-inflammatory adj (agent* or drug $\left.{ }^{\star}\right)$ ).tw.

3. (nonsteroidal anti-inflammatory adj (agent* or drug $\left.{ }^{\star}\right)$ ).tw.

4. (non-steroidal antiinflammatory adj (agent* or drug $\left.{ }^{\star}\right)$ ).tw.

5. (nonsteroidal antiinflammatory $\operatorname{adj}\left(\right.$ agent ${ }^{\star}$ or drug $\left.{ }^{\star}\right)$ ).tw.

6. NSAID*.tw.

7. exp Cyclooxygenase 2 Inhibitor/

8. $\operatorname{cox} 2$ inhibitor ${ }^{\star}$.tw.

9. (cyclooxygenase adj2 Inhibitor ${ }^{\star}$ ).tw.

Effects of peri-operative nonsteroidal anti-inflammatory drugs on post-operative kidney function for adults with normal kidney function 


\section{0.apazone.tw. \\ 11.aspirin.tw. \\ 12.clonixin.tw. \\ 13. diclofenac.tw. \\ 14.diflunisal.tw. \\ 15.epirizole.tw. \\ 16.fenoprofen.tw. \\ 17.feprazone.tw.}

18.flurbiprofen.tw.

19.ibuprofen.tw.

20.indomethacin.tw.

21.ketoprofen.tw.

22.ketorolac.tw.

23. meclofenamic acid.tw.

24. mefenamic acid.tw.

25.naproxen.tw.

26.niflumic acid.tw.

27.phenylbutazone.tw.

28. piroxicam.tw.

29.salicylates.tw.

30.sulindac.tw.

31.tolmetin.tw.

32.celecoxib.tw.

33.etodolac.tw.

34.tenoxicam.tw.

35.parecoxib.tw.

36.rofecoxib.tw.

37.meloxicam.tw.

38.valdecoxib.tw.

39.or/1-38

40.exp Analgesia/

41.analgesi ${ }^{\star} . t w$.

42.an?esthesia.tw.

43.Pain/

44.Postoperative Pain/

45.Postoperative Period/

46.Postoperative Analgesia/

47.Perioperative Period/

48.Preoperative Period/

49.Postoperative Complication/

50.(postoperative or post-operative).tw.

51.(peri-operative or perioperative).tw.

52.(preoperative or pre-operative).tw.

53.pain.tw.

54.or/40-53

55.and $/ 39,54$

56.Kidney/

57.Kidney Disease/

58.Kidney Failure/

59.Acute Kidney Failure/

60.Creatinine/

Effects of peri-operative nonsteroidal anti-inflammatory drugs on post-operative kidney function for adults with normal kidney function 


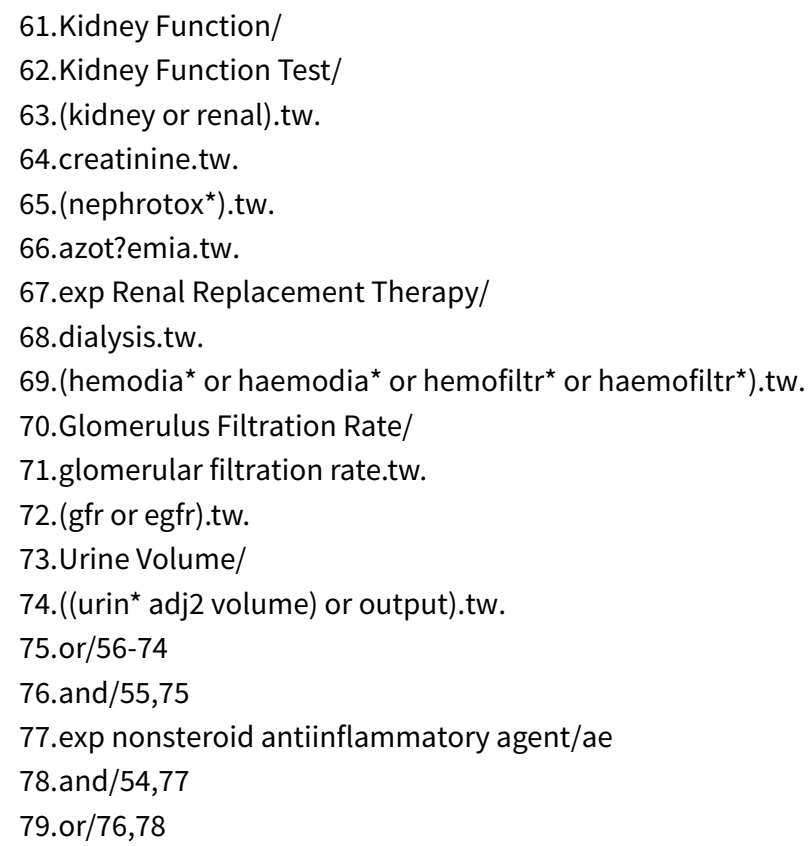

\section{Appendix 2. Risk of bias assessment tool}

\begin{tabular}{ll}
\hline Potential source of bias & Assessment criteria \\
\hline $\begin{array}{l}\text { Random sequence genera- } \\
\text { tion }\end{array}$ & $\begin{array}{l}\text { Low risk of bias: Random number table; computer random number generator; coin tossing; shuf- } \\
\text { fling cards or envelopes; throwing dice; drawing of lots; minimization (minimization may be imple- } \\
\text { mented without a random element, and this is considered to be equivalent to being random). }\end{array}$ \\
\cline { 2 - 2 } $\begin{array}{l}\text { Selection bias (biased alloca- } \\
\text { tion to interventions) due to } \\
\text { inadequate generation of a } \\
\text { randomised sequence }\end{array}$ & $\begin{array}{l}\text { High risk of bias: Sequence generated by odd or even date of birth; date (or day) of admission; se- } \\
\text { quence generated by hospital or clinic record number; allocation by judgement of the clinician; by } \\
\text { preference of the participant; based on the results of a laboratory test or a series of tests; by avail- } \\
\text { ability of the intervention. }\end{array}$
\end{tabular}

Unclear: Insufficient information about the sequence generation process to permit judgement.

\section{Allocation concealment}

Selection bias (biased allocation to interventions) due to inadequate concealment of allocations prior to assignment
Low risk of bias: Randomisation method described that would not allow investigator/participant to know or influence intervention group before eligible participant entered in the study (e.g. central allocation, including telephone, web-based, and pharmacy-controlled, randomisation; sequentially numbered drug containers of identical appearance; sequentially numbered, opaque, sealed envelopes).

High risk of bias: Using an open random allocation schedule (e.g. a list of random numbers); assignment envelopes were used without appropriate safeguards (e.g. if envelopes were unsealed or non-opaque or not sequentially numbered); alternation or rotation; date of birth; case record number; any other explicitly unconcealed procedure.

Unclear: Randomisation stated but no information on method used is available.

Low risk of bias: No blinding or incomplete blinding, but the review authors judge that the outcome is not likely to be influenced by lack of blinding; blinding of participants and key study personnel ensured, and unlikely that the blinding could have been broken.

\section{Blinding of participants and personnel}

Performance bias due to knowledge of the allocated

Effects of peri-operative nonsteroidal anti-inflammatory drugs on post-operative kidney function for adults with normal kidney function 
(Continued) interventions by participants and personnel during the study
High risk of bias: No blinding or incomplete blinding, and the outcome is likely to be influenced by lack of blinding; blinding of key study participants and personnel attempted, but likely that the blinding could have been broken, and the outcome is likely to be influenced by lack of blinding.

Unclear: Insufficient information to permit judgement

\section{Blinding of outcome assess- ment}

Detection bias due to knowledge of the allocated interventions by outcome assessors.
Low risk of bias: No blinding of outcome assessment, but the review authors judge that the outcome measurement is not likely to be influenced by lack of blinding; blinding of outcome assessment ensured, and unlikely that the blinding could have been broken.

High risk of bias: No blinding of outcome assessment, and the outcome measurement is likely to be influenced by lack of blinding; blinding of outcome assessment, but likely that the blinding could have been broken, and the outcome measurement is likely to be influenced by lack of blinding.

Unclear: Insufficient information to permit judgement

\section{Incomplete outcome data}

Attrition bias due to amount, nature or handling of incomplete outcome data.
Low risk of bias: No missing outcome data; reasons for missing outcome data unlikely to be related to true outcome (for survival data, censoring unlikely to be introducing bias); missing outcome data balanced in numbers across intervention groups, with similar reasons for missing data across groups; for dichotomous outcome data, the proportion of missing outcomes compared with observed event risk not enough to have a clinically relevant impact on the intervention effect estimate; for continuous outcome data, plausible effect size (difference in means or standardized difference in means) among missing outcomes not enough to have a clinically relevant impact on observed effect size; missing data have been imputed using appropriate methods.

High risk of bias: Reason for missing outcome data likely to be related to true outcome, with either imbalance in numbers or reasons for missing data across intervention groups; for dichotomous outcome data, the proportion of missing outcomes compared with observed event risk enough to induce clinically relevant bias in intervention effect estimate; for continuous outcome data, plausible effect size (difference in means or standardized difference in means) among missing outcomes enough to induce clinically relevant bias in observed effect size; 'as-treated' analysis done with substantial departure of the intervention received from that assigned at randomisation; potentially inappropriate application of simple imputation.

Unclear: Insufficient information to permit judgement

\section{Selective reporting}

Reporting bias due to selective outcome reporting
Low risk of bias: The study protocol is available and all of the study's pre-specified (primary and secondary) outcomes that are of interest in the review have been reported in the pre-specified way; the study protocol is not available but it is clear that the published reports include all expected outcomes, including those that were pre-specified (convincing text of this nature may be uncommon).

High risk of bias: Not all of the study's pre-specified primary outcomes have been reported; one or more primary outcomes is reported using measurements, analysis methods or subsets of the data (e.g. subscales) that were not pre-specified; one or more reported primary outcomes were not prespecified (unless clear justification for their reporting is provided, such as an unexpected adverse effect); one or more outcomes of interest in the review are reported incompletely so that they cannot be entered in a meta-analysis; the study report fails to include results for a key outcome that would be expected to have been reported for such a study.

Unclear: Insufficient information to permit judgement

\section{Other bias}

Bias due to problems not covered elsewhere in the table
Low risk of bias: The study appears to be free of other sources of bias.

High risk of bias: Had a potential source of bias related to the specific study design used; stopped early due to some data-dependent process (including a formal-stopping rule); had extreme baseline imbalance; has been claimed to have been fraudulent; had some other problem. 
Unclear: Insufficient information to assess whether an important risk of bias exists; insufficient rationale or evidence that an identified problem will introduce bias.

\section{Appendix 3. Decisions based on five GRADE criteria about certainty of evidence from RCTs in Summary of Findings Table}

Outcome: post-operative acute kidney injury

\begin{tabular}{lll}
\hline Criterion & Evidence & Decision \\
\hline Risk of bias & $\begin{array}{l}\text { NAFARM 2011 had unclear selection bias but the } \\
\text { POISE-2 2013 was at low risk of bias }\end{array}$ & Not serious \\
\hline Imprecision & 7066 participants and 897 events & $\begin{array}{l}\text { Serious: POISE-2 2013 had few events while NAFARM } \\
\text { 2011 was stopped early }\end{array}$ \\
\hline Inconsistency & Chi2 $=2.43$, df $=1(P=0.12) ;\left.\right|^{2}=59 \%$ & $\begin{array}{l}\text { Serious: the risk of AKI in the control groups was com- } \\
\text { pletely different: } 1.2 \% \text { in NAFARM 2011 versus 12.3\% in } \\
\text { POISE-2 2013 }\end{array}$ \\
\hline Indirectness & $\begin{array}{l}\text { The indications for NSAID were prevention of AKI } \\
\text { (POISE-2 2013) or atrial fibrillation (NAFARM 2011) } \\
\text { rather than analgesia }\end{array}$ & $\begin{array}{l}\text { Serious because the doses for these indications were } \\
\text { lower than the doses that would be used for analgesia } \\
\text { in routine care }\end{array}$ \\
\hline Publication bias & $\begin{array}{l}\text { Large studies, not commercially sponsored other } \\
\text { than supply of intervention drugs and placebo }\end{array}$ & \begin{tabular}{l} 
Not serious \\
\hline
\end{tabular} \\
\hline
\end{tabular}

Outcome: difference in increase in post-operative serum creatinine

\begin{tabular}{lll}
\hline Criterion & Evidence & Decision \\
\hline Risk of bias & $\begin{array}{l}\text { Eight studies had high risk of } \\
\text { bias overall or high risk of attri- } \\
\text { tion bias }\end{array}$ & $\begin{array}{l}\text { Not serious: the mean difference in SCr was higher in the six studies with } \\
\text { low or unclear risk of bias }(3.45,0.12 \text { to } 6.78) \text { than in all 15 studies (3.23, } \\
-0.80 \text { to } 7.26)\end{array}$ \\
\hline Imprecision & N94 participants & Not serious \\
\hline Inconsistency & $\begin{array}{l}\text { Chi2 }=40.98, \mathrm{df}=14(\mathrm{P}=0.0002) ; \\
\mathrm{I}^{2}=66 \%\end{array}$ & $\begin{array}{l}\text { Serious: the inconsistency was not adequately explained by pre-specified } \\
\text { effect modifiers (Table } 1)\end{array}$ \\
\hline Indirectness & $\begin{array}{l}\text { All of the studies had multiple } \\
\text { exclusion criteria, including age } \\
\text { in } 6 \text { (Table } 1)\end{array}$ & $\begin{array}{l}\text { Serious: the patients in these RCTs are likely to be different from those in } \\
\text { routine care. The results of Kulik 2004 (decrease in SCr associated with } \\
\text { naproxen for } 5 \text { days after cardiac surgery) are in stark contrast to the results } \\
\text { of NAFARM 2011 (trial stopped because of excess risk of acute kidney injury } \\
\text { associated a lower dose of naproxen for } 5 \text { days after cardiac surgery) }\end{array}$ \\
\hline $\begin{array}{l}\text { Publication bias } \\
\text { None of the studies were com- }\end{array}$ & $\begin{array}{l}\text { Not serious } \\
\text { mercially sponsored }\end{array}$ \\
\hline
\end{tabular}




\section{Outcome: renal replacement therapy}

\begin{tabular}{lll}
\hline Criterion & Evidence & Decision \\
\hline Risk of bias & $\begin{array}{l}\text { Rafiq 2014 was at high risk of performance and detec- } \\
\text { tion bias }\end{array}$ & Serious \\
\hline Imprecision & 7056 participants, 31 events & Serious, few events \\
\hline Inconsistency & Chi2 $=1.35, \mathrm{df}=1(\mathrm{P}=0.25) ; \mathrm{I}^{2}=26 \%$ & $\begin{array}{l}\text { Serious: the risk of RRT in the control groups was } \\
\text { completely different: 0.3\% in NAFARM 2011 versus } \\
2.7 \% \text { in Rafiq 2014 }\end{array}$ \\
\hline Indirectness & $\begin{array}{l}\text { The indications for NSAID was prevention of atrial fib- } \\
\text { rillation in the largest study (NAFARM 2011) rather than } \\
\text { analgesia }\end{array}$ & $\begin{array}{l}\text { Serious because the dose of naproxen in NAFARM } \\
2011 \text { was much lower than would be used for anal- } \\
\text { gesia }\end{array}$ \\
\hline Publication bias & None of the studies were commercially sponsored & Not serious \\
\hline
\end{tabular}

\section{Outcome: death}

\begin{tabular}{lll}
\hline Criterion & Evidence & Decision \\
\hline Risk of bias & $\begin{array}{l}\text { Rafiq 2014 was at high risk of performance and detection } \\
\text { bias }\end{array}$ & Serious \\
\hline Imprecision & 312 participants, 8 events & Serious: few events \\
\hline Inconsistency & Chi2 $=1.61, \mathrm{df}=1(\mathrm{P}=0.20) ; \mathrm{I}^{2}=39 \%$ & $\begin{array}{l}\text { Serious: the relative risk of death was in oppo- } \\
\text { site directions: 3.85 in NAFARM 2011 versus 0.48 in } \\
\text { Rafiq 2014 }\end{array}$ \\
\hline Indirectness & $\begin{array}{l}\text { The indications for NSAID was prevention of atrial fib- } \\
\text { rillation in the largest study (NAFARM 2011) rather than } \\
\text { analgesia }\end{array}$ & $\begin{array}{l}\text { Serious: the dose of naproxen in NAFARM 2011 was } \\
\text { much lower than would be used for analgesia }\end{array}$ \\
\hline Publication bias & None of the studies were commercially sponsored & \begin{tabular}{l} 
Not serious \\
\hline
\end{tabular}
\end{tabular}

\section{Outcome: length of hospital stay}

\begin{tabular}{lll}
\hline Criterion & Evidence & Decision \\
\hline Risk of bias & $\begin{array}{l}\text { Rafiq 2014 was at high risk of performance and detection } \\
\text { bias; Kulik 2004 was at high risk of attrition bias }\end{array}$ & Serious \\
\hline Imprecision & 410 participants & $\begin{array}{l}\text { Not serious: length of stay measured in all partici- } \\
\text { pants }\end{array}$ \\
\hline
\end{tabular}


(Continued)

Inconsistency $\quad \mathrm{Chi}^{2}=2.63, \mathrm{df}=1(\mathrm{P}=0.27) ; \mathrm{I}^{2}=24 \%$

Serious: mean length of stay in control groups varied from 5.4 (Kulik 2004) to 17.2 days (NAFARM 2011)

Indirectness The indications for NSAID was prevention of atrial fib-

Serious: the dose of naproxen in NAFARM 2011 was rillation in the largest study (NAFARM 2011) rather than much lower than would be used for analgesia analgesia

Publication bias None of the studies were commercially sponsored Not serious

\section{CONTRIBUTIONS OFAUTHORS}

1. Draft the protocol: $S B$

2. Study selection: $\mathrm{SB}, \mathrm{TR}$

3. Extract data from studies: $S B, T R$

4. Enter data into RevMan: $S B$

5. Carry out the analysis: $\mathrm{SB}, \mathrm{CM}, \mathrm{PD}$

6. Interpret the analysis: $\mathrm{SB}, \mathrm{CM}, \mathrm{PD}$

7. Draft the final review: $\mathrm{SB}, \mathrm{TR}, \mathrm{CM}, \mathrm{PD}$

8. Disagreement resolution: $P D$

9. Update the review: SB

\section{DECLARATIONS OF INTEREST}

- Samira Bell: none known

- Charis A Marwick: none known

- Trijntje Rennie: none known

- Peter Davey: none known

\section{SOURCES OF SUPPORT}

\section{Internal sources}

- University of Dundee and National Health Service Tayside, UK.

\section{External sources}

- No sources of support supplied

\section{DIFFERENCES BETWEEN PROTOCOLAND REVIEW}

We did not perform a search for observational studies as outlined in the protocol as we found sufficient RCTs to address the aim of the review. We included two studies that had an objective other than pain relief in this review. NAFARM 2011 studied the effects of naproxen on prevention of atrial fibrillation after coronary artery bypass grafting and the POISE-2 2013 studied adverse effects of low dose aspirin following non-cardiac surgery.

\section{INDEX TERMS}

\section{Medical Subject Headings (MeSH)}

Acute Kidney Injury [chemically induced]; Anti-Inflammatory Agents, Non-Steroidal [ ${ }^{\star}$ adverse effects]; Creatinine [blood]; Kidney [ ${ }^{*}$ drug effects] [physiology]; Length of Stay; Pain, Postoperative [ ${ }^{*}$ drug therapy]; Perioperative Care; Randomized Controlled Trials as Topic; Renal Insufficiency [chemically induced]; Urine

\section{MeSH check words}

Adult; Humans; Male 